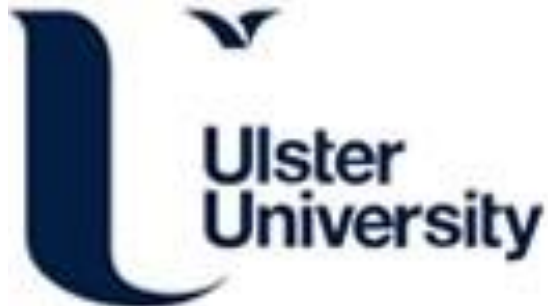

\section{Causal Relationships between the Price-to-Rent ratio and macroeconomic factors: A UK Perspective}

Lo, D., McCord, M., McCord, J., Davis, PT., \& Haran, M. (2022). Causal Relationships between the Price-toRent ratio and macroeconomic factors: A UK Perspective. Journal of Property Investment and Finance. https://doi.org/10.1108/JPIF-08-2021-0068

Link to publication record in Ulster University Research Portal

Published in:

Journal of Property Investment and Finance

Publication Status:

Published online: 02/02/2022

DOI:

10.1108/JPIF-08-2021-0068

\section{Document Version}

Author Accepted version

\section{General rights}

Copyright for the publications made accessible via Ulster University's Research Portal is retained by the author(s) and / or other copyright owners and it is a condition of accessing these publications that users recognise and abide by the legal requirements associated with these rights.

\section{Take down policy}

The Research Portal is Ulster University's institutional repository that provides access to Ulster's research outputs. Every effort has been made to ensure that content in the Research Portal does not infringe any person's rights, or applicable UK laws. If you discover content in the Research Portal that you believe breaches copyright or violates any law, please contact pure-support@ulster.ac.uk. 


\section{Journal of Property Investment \& F}

\section{Causal Relationships between the Price-to-Rent ratio and macroeconomic factors: A UK Perspective}

\begin{tabular}{|r|l|}
\hline Journal: & Journal of Property Investment \& Finance \\
\hline Manuscript ID & JPIF-08-2021-0068.R1 \\
\hline Manuscript Type: & Academic Paper \\
\hline Keywords: & $\begin{array}{l}\text { Price-to-rent, Macroeconomics, Residential real estate, Cointegration, } \\
\text { Causality, The United Kingdom }\end{array}$ \\
\hline \multicolumn{2}{|l}{} \\
\hline
\end{tabular}

\section{SCHOLARONE \\ Manuscripts}


Causal Relationships between the Price-to-Rent ratio and Macroeconomic factors: A UK Perspective

\begin{abstract}
House Price-to-Rent (P-t-R) ratios are among the most widely used measure of housing market conditions. Given the theoretical and apparent bi-directional, causal relationships and imbalances between the housing market, broader economy and financial market determinants, it is important to understand the relationship between macro- and micro-economic characteristics in relation to the P-t-R ratio to enhance the understanding of housing market dynamics. This paper studies the joint dynamics and persistence of house prices and rents and examines the temporal interactions of the P-t-R ratio and economic and financial determinants. Specifically, we examine this relationship using cointegration and causality methods, initially at the aggregate position, and also across housing types within the housing market to establish whether there are subtle differences in how various housing segments react to changes in economic activity and market fundamentals. The findings reveal price switching dynamics and some very distinct long- and short-run relationships between macroeconomic and financial indicators and the P-t-R ratios across the various housing segments. The results exhibit monetary supply, foreign exchange markets and the stock market to be important drivers of the P-t-R ratio, with price to rent movements seemingly tied, or are in tandem, with the overall economy, particularly with the construction sector. Indeed, the findings show that the P-t-R ratio can be used as an early measure for establishing the effects of macroprudential policy changes and how these may manifest across housing tiers and quality, and further act as a signal for preventing or at least mitigating future irrational price cyclicity. These insights serve to inform housing and economic policy and macroprudential policy design, principally within lending policy, and the effect of regulatory interventions and further enhance the understanding of the P-t-R ratio on housing market structure and dynamics.
\end{abstract}




\section{Introduction}

In the immediate aftermath of the GFC, discernible policy reforms, particularly within the macroprudential and banking settings resulted in changes within the structure of the housing market. Since then, the recovery and indeed growth in house prices allied with wider economic stability and revival alongside fluid macroprudential policy has further transformed the composition and structure of housing markets in terms of both demand and supply fundamentals and equilibrium prices (Bryne and Norris, 2018). Alongside these developments, structural reforms within the private rental sector (PRS) have also been ubiquitous (globally) within housing systems due to the combined forces of policy change, financialisation, cyclic nature of credit markets (Lo et al., 2021), impacting upon market processes and disequilibrium between rental and housing prices and local market fundamentals (Hulse and Yates, 2017).

Indeed, fluctuations in house prices can connote sharp impacts on real economic activity (Granziera and Kozicki, 2015), with movements in house prices impacting upon the real side of the economy through their effect on the financial system, leading to fluctuations in macroeconomic and financial stability - commencing with the stock market (Kishor and Morley, 2015). As Gilbukh, Haughwout and Tracy (2017) contend, the cyclicity of house prices necessitates the need to design macroprudential policies that mitigate future housing cycles. An essential component of this is the role of credit and the design of macroprudential tools that reduce the procyclicality of origination loan-to-value (LTV) ratios (Borgersen, 2020). Further, the varying nature of house prices results in house prices trend reverting in relation to fundamental value. This process however adversely impacts on demand and supply for housing via the construction sector. In light of these considerations, it is important to identify the determinants of house prices dynamics.

Accordingly, the Price-to-Rent (P-t-R) ratios offer important housing market insights (Begley et al., 2019), providing information about local real estate markets, including future market expectations and speculative market behaviour and asset pricing bubbles. In this regard, the P-t-R ratio is frequently used as an indicator for assessing housing market equilibrium through clearing of housing and rental markets (Borgersen, 2020) and overvaluation (Kishor and Morley, 2015), with departures from equilibrium detected by comparing the P-t-R ratio with the user-cost equilibrium condition (Hill and Syed, 2016). Indeed, housing literature contends that housing market frictions such as non-convex transaction costs, tax advantages to homeownership, and higher depreciation of rental properties relative to owneroccupied properties are likely to be important determinants of housing demand and rental supply (Sommer et al., 2010) and in the determination of the P-t-R ratio. Further Borgersen (2020) illustrates that the context-specific effect of LTV on the P-t-R-ratio links housing markets to mortgage markets and monetary policy. These changes signal a possible deviation from the underlying market and economic fundamentals and it has long been considered that divergence from long-term values of prices in relation to rents is a cause for concern (Sommer et al., 2010). 
Given the theoretical and apparent bi-directional, causal relationships and imbalances between the housing market, broader economy, financial environment and market fundamentals it is important to understand the relationship between macro- and micro-economic characteristics in relation to the P-t-R ratio to enhance the understanding of housing market dynamics. As Borgersen (2020) emphasises, although the P-t-R ratio is widely used as a measure of over- and undervaluation in the housing market, surprisingly little is known about the theoretical relationship between the P-t-R ratio and market fundamentals such as interest rates and down payment requirements.

This paper therefore examines the temporal interactions of the P-t-R ratio and economic and financial determinants. Specifically, we examine this relationship at the aggregate position and also across housing types within the housing market to establish whether there are subtle differences in how various housing segments react to changes in economic activity and market fundamentals. To do so, we apply cointegration and causality methods to determine whether there is any short- and long-term lead-lag relationships between the different property types with respect to their P-t-R ratios and macroeconomic variables. These insights serve to inform housing and economic policy and macroprudential policy design and the effect of regulatory interventions and further enhance the understanding of the P-t-R ratio on housing market structure and dynamics.

The reminder of the paper is presented as follows: Section 2 discusses the literature with particular emphasis placed on the macroeconomic attributes that affect the P-t-R ratio in various international housing markets. Section 3 describes the research methodology of the study, covering the technical aspects of the various statistical tests employed. It also depicts the sample data and provides some useful descriptive statistics on the Northern Ireland residential market. Section 4 reports the results of the empirical tests, including those of the Cointegration and Granger Causality with Section 5 discussing the key research findings arising from the empirical tests. The last section concludes the study, which summarises the findings, discusses potential implications, provides directions for future research in the topic area.

\section{Literature Review}

Housing market equilibrium can be assessed from a number of perspectives and angles. From a price determination perspective, the causal interaction between real estate pricing and rents as well as the relationships between the P-t-R and other economic fundamentals are enshrined in the DiPasquale and Wheaton's Four-quadrant Model (1992). The Model portrays that price is determined by, or lags, rents since the former could be viewed as the summation of all future discounted rental incomes. The total amount of housing stock and the demand for real estate jointly affect the level of rent, which subsequently result in a change in the price level through the process of capitalisation. The rate of capitalisation is commonly termed as the current yield of the housing investment, which is the 
opportunity cost or profitability rate that property traders require to acquire property assets. Based on the Model, four main economic factors jointly determine the fashion in which the current yield is formed in the long-run, namely the expected growth rate in rental income, the long-term interest rate, the overall risk associated with the generation of rental income, and relevant taxation policy. The theorisation of the Model is indeed inspired by other seminal works such as Fisher (1930) and Rae (1934) who examined interest rate as a principal factor governing the pricing of various commodities, as well as the variation of utility of a given commodity with respect to the change in opportunity cost. Nonetheless, Colwell (2012) and other critics of the Model indicated that the DW approach is not sufficiently detailed, in that investor's expectation about future rental growth is not captured by the Model, which could cause issues when explaining the underlying dynamics and interaction between P-t-R and other real estate market attributes.

A number of studies in the literature have attempted to explain the joint dynamics of property prices and rents utilising different methodological approaches and datasets. Sommer et al. (2010), for instance, examined the association between property prices and rents for the USA by employing a dynamic equilibrium stochastic life-cycle model of housing tenure choice. Their findings suggested that more than $50 \%$ of the increase in the US resident property P-t-R ratio between the period of 1995 and 2005 was attributable to lower interest rates, less restrictive lending requirements and higher income levels. These three factors also resulted in more rapidly increasing property prices, sluggish rents, increasing homeownership and higher household indebtedness during the investigation period.

In a similar study, Kishor and Morley (2015) examined various factors that affect the P-t-R ratios of the eighteen metropolitan statistical areas (MSAs) in the U.S by conducting a present value analysis based on Campbell and Shiller's (1988) modelling framework. In their study, they decompose the P-t-R ratio into two parts which are assumed to follow exogenously specified time series processes, namely an unobserved component which is governed by the real rental growth rate and the expected real estate return, and a residual component which accounts for non-stationary temporal deviations of the P-t-R ratio from its conventional present value level (PVR). It is observed that the PVR components were approximately $30 \%$ larger than the size implied by the present value model for large MSAs such as New York, Los Angeles and Miami during a property boom period. The empirical results further revealed that MSAs whose deviations from the PVR are large are more responsive to change in mortgage rates, which implies a high degree of heterogeneity with respect to monetary policy. In addition, the authors uncovered that housing supply elasticity tended to be correlated to PVR, inferring that MSAs with larger PVR are statistically likely to exhibit inelastic housing supply. The findings also confirmed an empirical phenomenon that P-t-R ratios tend to persist over time in the sense that MSAs with higher PVRs are the same MSAs that demonstrate the same pricing characteristics during different bull market periods. On the other hand, a large portion of the variation in the present-value component of the P-r-R is determined by the variation in the expected real estate returns. 
In a similar paper, Campbell et al. (2009) in a variance decomposition of the P-t-R ratio applied a dynamic Gordon growth model across 23 US metropolitan areas over the period 1975 to 2007. Dissecting the P-t-R ratio to be compartmentalised into the expected present discounted values of rent growth, real interest rates, and a housing premium over real rates, the authors established that housing premia account for a significant fraction of rent-price ratio volatility at both the national and local level. More recently, Begley et al. (2019) applied micro-level data to examine what they term the joint evolution of prices and rents concentrating on the owner-occupied sector. Decomposing the change in prices into three components, namely, the change in rents, relative price of investor and owner-occupied property and changes in the P-t-R ratio, they reveal that the P-t-R ratio accounts for most of the variation, and further reveal that this moves similarly across all property types. However, they note that this varies significantly by geography.

In a Chinese context, Wu and Jiang (2012) evaluate the price-to-rent and price-to-income ratios across a number of urban areas. Their findings indicated that high house price increases result in distortions between the relationship and forcing rental price inflation posing structural challenges in terms of supporting the mainstream market. Concomitantly, the authors show that the price-to-income ratio varies in different cities identifying that a paradox exists amongst groups with different income levels. In a comparative study, Feng-jun (2011) using inter-provincial panel data for 35 large or medium cities in China, empirically assesses the P-t-R showing that the ratio bears positive affection to the speed of urbanisation.

Borgersen (2020) provides a conceptually different approach by distilling out the relationship between the loan-to-value (LTV) ratio and the price-rent (PR) ratio through incorporating the funding structure of housing investment. By formalising the relationship between leverage and housing return, as suggested by Muellbauer and Murphy (1997), the authors found the effect of a higher LTV on the user cost of housing as the net effect of a higher borrowing cost and the associated leverage gain, showing that the latter is dependent upon the relationship between house price growth and mortgage rates. Numerous other empirical studies within housing literature have shed light on the P-t-Rs of the U.K. and the Irish residential property markets. Prominent works include Bracke (2015) who investigated the micro-spatial house price dynamics within central London, highlighting that the level of affluence of a given neighbourhood is closely associated with P-t-R. Indeed, the study echoed the findings of previous research by Smith and Smith (2006) who demonstrated that high-end houses in ten sample US urban residential markets exhibited larger P-t-R ratios than those of low-end counterparts.

More recently, Clark and Lomax (2019) utilised matched transaction and rental data of dwellings in England to examine the impact of location and property type upon the variation of P-t-R ratio in different residential submarkets, establishing a relationship that the physical desirability of a property or neighbourhood is intimately linked to the ratio with better housing generally displaying a higher P- 
t-R. In addition, the study revealed that detached and semi-detached houses, relative to apartments and terraced houses, exhibited higher P-t-R ratios, whilst distance to city centre and time on the market (i.e. the length of time between listing and sale) are factors that depress P-t-R.

In the context of the Irish property market, Kim and Lim (2014) explored the variations in the P-t-R ratio between 1976 and 2012 in the framework of the Campbell-Shiller present value equation, which was designed to decompose the P-t-R into the present discounted values of expected future real estate market fundamentals. The results, based on the maximum likelihood estimation approach, suggested that the variations in the P-t-R ratio can, in a large part, be explained by the expected housing premium, whereas real interest rates and expected rental growth are less significant factors affecting the ratio. Cronin and McQuinn (2016) also examined the economic effects of macroprudential policy specific to housing tenure, finding reductions in loan-to-value ratios result in increased demand for rental accommodation and thus higher rents for a given house price level.

More recently, Lo et al. (2021) empirically demonstrated that P-t-R ratio is highly dependent on the characteristics of the property submarket concerned. Specifically, by examining the Belfast (U. K.) residential market at a submarket level, the study revealed that the detached sector exhibited the highest as well as the most volatile P-t-R ratio, partially attributable to the fact that the sector tended to deliver its returns primarily through capital growth, not rental yield appreciation. Another significant and novel finding that can be deduced from the investigation is that the P-t-R ratios of the property sub-markets (including detached, semi-detached and terraced markets) are highly cointegrated in the long-run, with the detached sector Granger-causing the P-t-R movements of other sectors. On the other hand, the findings showed the apartment sub-market sector displayed somewhat unique P-t-R features revealing no persistence or Granger causal relationships with the detached and semi-detached sectors but with the terraced and townhouse sectors. Further, the study of McCord et al. (2019) empirically tested the comovement in-house prices across different property types within Northern Ireland to determine whether price transmissions are propagated contemporaneously into both short-term and long-term price adjustments. Their study established stylised facts of lead-lag relationships across property types finding that the apartment sector systematically and consistently lagged behind all other residential property segments pointing towards obvious market filtration transmission pricing signals in operation in a Granger-causal fashion with property price signals transmitted from the more liquid owneroccupier-led Detached and Semi-detached segments to the Apartment segment, but not vice versa. There has been a number of studies which have examined the P-t-R conceptually. From a market perspective, whilst research has examined the P-t-R ratio from a life-cycle model of housing tenure choice or present value perspective, there remains more limited insights pertaining to examining temporal variations of the P-t-R ratio with market determinants and macroeconomic and financial factors. Moreover, there remains little empirical work, certainly in the UK perspective, investigating the causal dynamics and relationships of P-t-R ratios by property type which theoretically may be driven 
by changes in different market and economic determinants and house price and rent movements. McCord et al. (2019), put forward an explanation that, relative to the detached sector, the terraced and townhouse sectors are close substitutes of the apartment sector, hence the latter three sectors should share similar pricing dynamics, behaviour and causal interactions in the long-run. Begley et al. (2019) also decomposing price changes revealed that the P-t-R moved comparably across all property types. Therefore we test these propositions whilst accounting for wider economic and financial factors moving forward.

\section{Data and Methodology}

In this study, we employ Johansen Cointegration and Granger causality techniques to test for, if any, the existence of cointegration and lead-lag relationships between the price to rent ratios of different property submarkets and a spectrum of macroeconomic and financial variables that we surmise may have a long-term association with the real estate market. The investigation period is 2014Q1 to 2018Q4, which was purposely chosen to minimise the effects arising from exogenous influences given the relatively stable market environment compared to historical trends, thereby enhancing the overall robustness of the study. Accordingly, we create a quarterly time series for the P-t-R ratio of the Northern Ireland residential market $\left(P R_{A}\right)$ using quarterly prices and rents which are derived from an established property index (UU HPI) and rental index ${ }^{1}$ which are calculated based on large and representative sample size of open market transactions ${ }^{2}$ in Northern Ireland.

Further, to empirically examine the price/rent dynamics of the aggregate residential property market, we examine the P-t-R ratios of the four main property sub-markets of the region, including (i) Detached $\left(P R_{d}\right)$, (ii) Semi-detached $\left(P R_{S}\right)$, (iii) Terraced $\left(P R_{t}\right)$, (iv) Apartment $\left(P R_{a}\right)$. We conjecture that each of these sub-market segments might exhibit varying degrees of association/disassociation with the array of macroeconomic indicators investigated by virtue of its own underlying demand and supply fundamentals. These macroeconomic factors consider various aspects of the general economy, including (i) inflation, (ii) interest rates, (iii) stock market performance, (iv) exchange rates, (v) money supply, (vi) general economic productivity, (vii) the productivity of the construction sector, and (viii) housing stock.

\section{Macroeconomic, financial and market variables}

The Inflation rate (IR), proxied by Consumer Price Index (CPI), measures the general price level of goods and services typically purchased by the households in the U.K. The data source is The Office for

\footnotetext{
${ }^{1}$ The rental index commenced in 2014 Q1.

2 The UU HPI was established in 1984 and records circa $40 \%$ of residential property transactions across the region of NI. The HPI measures the current price and quantities in relation to the base period. The index is based on quarterly returns obtained from 103 contributory estate agency practices from across Northern Ireland and supplemented with recorded and verified sale transactions from Propertynews.com. The sales information is also cross-correlated with the domestic capital valuation register for inspection and verification of attribute information.
} 
National Statistics, U.K. which conducts surveys on a monthly basis on approximately 20,000 outlets within the country to track the price movements of over 700 goods and services. It is noted that the CPI is calculated on a year-on-year basis. We contend that the potential effect of inflation on the P-t-R ratio could be empirical ambiguous depending critically on the actual fundamentals of the market: If the general price level indeed moves in tandem with the property market, then a surging inflation rate should on average lead to higher property prices, and hence a higher average P-t-R ratio, given that rents tend to lag behind residential sales prices due to the contractual rigidity in making rental adjustments; on the other hand, inflation could erode the overall purchasing power of the potential homebuyers, reducing the demand for housing. In this scenario, the P-t-R ratio should decrease.

Mortgage Interest Rates (MIR) are measured by the two-year household variable mortgage rate in the U.K., which represents the cost of capital or borrowing for prospective purchasers. Theoretically speaking, a higher interest rate should depress housing prices, which in turn should result in a lower P-t-R ratios assuming the rental movements remain constant. The data is obtained from Federal Reserve Bank of St Louis, and is measured on a quarterly basis. To test any potential impact of financial markets, the FTSE 100 Index (FTSE) is employed to proxy the general performance of the UK financial market, which is the most widely used stock market indicator for the country. The Index captures the performance of the largest 100 qualifying constituent companies (in the UK) by market capitalisation, covering a wide spectrum of industries including banking, energy, real estate, utilities, media and technology. Apart from the FTSE 100, we also consider the quarterly growth rates of the indices (FTSE_GROWTH) as an independent variable for robustness check in our analysis.

We contend that exchange rates between the British pound sterling and other major currencies could have a significant impact on the U.K. property market and any potential pricing arbitrage. Generally speaking, a lower value of one currency relative to others should attract more international investors to invest in the local real estate market, other things being equal, which should subsequently drive property prices up. Hence, the P-t-R ratio should increase when the currency depreciates against other currencies. In other words, the exchange rate can be viewed as an indicator measuring the relative attractiveness of domestic products, including real estate. In our study, we employ two exchange rates, namely EUR/GBP and USD/GBP, to proxy the relative attractiveness of the U.K. housing market from the perspective of foreign investors.

Money supply plays a critical role in the determination of the overall price level and inflation of an economy. The quantity theory of money states that the aggregate price level of an economy is directly proportional to the amount of money supply, holding the velocity of money and real output constant. Therefore, it is logical to posit that the P-t-R ratio of the NI housing market should have a close association with the supply of money. We utilise the growth rates of two of the most commonly-used money supply indicators, $\mathrm{M} 2$ and $\mathrm{M} 3$, as our explanatory and explained variables in the empirical tests. 
By definition, the former consists of cash, checking deposits, saving deposits, mutual funds, money market securities and time deposits whilst the latter captures all elements of M2 as well as institutional money market funds, short term repurchase agreements and other larger liquid assets such as marketable securities.

Numerous studies have established an empirical relationship between the general economic productivity and the real estate market, including Green (1997), Coulson and Kim (2000), Chan and Woo (2013). In our analysis, we employ the Northern Ireland Composite Economic Index (NICEI), compiled by the Northern Ireland Statistics and Research Agency (NISRA), to represent the overall output of the Northern Irish economy. The quarterly updated index is based on the economic performance of various sectors of the economy including construction, public services, manufacturing and private services. To the extent that the real estate market is in sync, or causally interlinked with the general economy, we should expect that the P-t-R ratio would be cointegrated and/or display a lead-lad relationship with NICEI.

Aside from examining the general economic productivity of Northern Ireland, we further explore the temporal relationship between the productivity of the construction sector and the real estate sector. We utilise the NICEI (Construction) sub-index to determine the total output of the construction. It is wellestablished in the DiPasquale and Wheaton Model (DiPasquale and Wheaton, 1992) that the output of the construction sector has a direct impact upon the price of real estate in general, with the degree of impact governed by the elasticity of the housing supply.

In our analysis, two indicators are utilised to investigate the effect of new housing stock on the P-t-R ratio, namely the total amount of new housing investment $\left(\mathrm{NH}_{t}\right)$ and the amount of new private housing investment $\left(\mathrm{NH}_{\mathrm{p}}\right)$, both measured in million pound sterling. Intuitively, we believe that the property prices and rents should be negatively affected by the amount of new housing supply coming to the market, holding other things constant. However, we suggest that the causal dimension of the relationship could be less clear empirically for the various housing submarkets examined since they exhibit different characteristics in relation to the underpinning demand-supply fundamentals, as well as the composition of the homebuyers. The data for this variable is obtained from NISRA who update the statistics on a quarterly basis.

\section{ADF Unit Root Tests}

Prior to undertaking our analysis, it is statistically important to test whether unit roots exist in the time series given that spurious empirical outcomes can occur if stationarity is not controlled for as this potentially undermines the inference power of the tests (Granger and Newbold, 1974; Banerjee et al., 1993). Therefore, we subject our analysis to the Augmented Dickey-Fuller (ADF) unit root test to check for unit roots of the time series. The general equation of the ADF test is given by: 


$$
\Delta Y_{t}=\alpha+\beta T+\emptyset Y_{t-1}+\sum_{i=1}^{k} \partial \Delta Y_{t-i}+\varepsilon_{t}
$$

where $Y_{t}$ is the level of the time series; $\alpha$ is an intercept term and $T$ is a time trend; $k$ denotes the total number of time periods for achieving white noise, which is governed by the Schwarz Information Criterion (SIC); and $\varepsilon_{t}$ is an error term with a zero mean and constant variances.

\section{Cointegration Tests}

We utilise the Johansen Cointegration tests developed by Johansen $(1991,1995)$ to detect whether long term cointegration relationships between a pair of time series exist. As a general rule, the components of a vector $V_{t} \sim \mathrm{CI}(\mathrm{i}, \mathrm{j})$ are said to be cointegrated of order $\mathrm{i}, \mathrm{j}$ if and only if $V_{t}$ is I(i) and we can find a non-zero vector $\alpha$ such that $\alpha^{\prime} V_{t} \sim \mathrm{I}(\mathrm{i}-\mathrm{j})$ where $\mathrm{i} \geq \mathrm{j}>0$. $\alpha$ is commonly known as cointegrating vector. Cointegration is said to exist if there is a long-term equilibrium relationship between these time series. To statistically observe whether there exists a cointegration relationship between two $I(1)$ variables, say, $X_{t}$ and $Y_{t}$, we run a regression of $Y_{t}$ on $X_{t}$ in line with Engle and Granger (1987). Unit root tests are then conducted to check the presence of unit root(s) in the regression residual of the equation. To achieve this, the following equation is formulated:

$Y_{t}=\alpha+\beta X_{t}+u_{t}$

Equation 2 is commonly known as cointegrating regression. $X_{t}$ and $Y_{t}$ are cointegrated if $u_{t}$ is a stationary time series, which can be vindicated by undertaking the ADF test on $u_{t}$. Nevertheless, Dickey et al. (1991) point out that the method proposed by Engle and Granger (1987) could indeed be sensitive to the choice of the regressand(s), potentially giving rise to inconsistent estimates. Alternatively, Johansen (1991 and 1995) suggests testing the following equation to conduct the cointegration test:

$\Delta Y_{t}=\eta Y_{t-1}+\sum_{i=1}^{k} \mathrm{r}_{i} \Delta Y_{t-i}+B X_{t}+\varepsilon_{t}$

where $\eta=\sum_{i=1}^{k} A_{i}-I$ and $\mathrm{r}_{i}=-\sum_{j=1+1}^{k} A_{i} . Y_{t}$ denotes a k-vector of $\mathrm{I}(1)$ that is non-stationary. $X_{t}$ is a $d$ vector of deterministic variables and $\varepsilon_{t}$ is a vector of white noises with zero mean and constant variance. $\eta$ represents the rank of the coefficient matrix, which indicates the number of cointegrating vectors.

Johansen (1991) further indicates that the cointegration test should be conducted by estimating $\eta$ in an unrestricted form to determine whether or not the restrictions suggested by the reduced rank of $\eta$ can be falsified. Trace test statistic can subsequently be obtained by conducting the likelihood ratio (LR) 
test for the hypothesis that there are at most $r$ cointegrating vectors. As suggested by Engle and Granger (1987), the variables of the analysis should be integrated of order one.

\section{Granger Causality Test in Error Correction Models (ECMs)}

As pointed out by Engle and Granger (1987) and Granger (1988), if two time series are cointegrated, the modeller could mis-specify their long term relationship if the traditional Granger method is utilised to test for causality. Hence, an ECM approach to Granger causality testing should be adopted and its equation can be expressed as follows:

$\Delta Y_{t}=\lambda++\sum_{i=1}^{p} \alpha_{i} \Delta Y_{t-i}+\sum_{j=1}^{q} \beta_{j} \Delta X_{t-j}+\phi z_{t-1}+\varepsilon_{t}$

where $\lambda$ is the constant term of the equation. $\mathrm{p}$ and $\mathrm{q}$ are the number of time lags that are large enough to obtain an error term $\varepsilon_{t}$ that is white noise. $z_{t-1}$ is commonly known as the error correction (EC) term and $\phi$ is the coefficient to be estimated.

An ECM Granger causality test is of great statistical appeal in the sense that it is informationally implicative. It detects both short- and long-run equilibriums and/or dynamics of a given pair of time series that are cointegrated. In Equation (4), $\beta_{j}{ }^{\prime} s$, which indicates the impact of lagged independent variables $\Delta X_{t-j}$, represents the short-term impact of $Y$ on change in $X$. In other words, $\beta_{j}$ measures the short term elasticity of $\mathrm{Y}$ with respect to $\mathrm{X}$. On the other hand, $z_{t-1}$ signals the long run dynamic between the two variables. Mathematically, $z_{t-1}$ takes the form of:

$z_{t-1}=Y_{t-1}-w_{0}-w_{1} X_{t-1}+w_{2} t$

$w_{1}$ is the coefficient of $X_{t-1}$, which indicates the magnitude of long run elasticity of $Y$ with respect to $\mathrm{X}$ (Thomas, 1997). $\mathrm{t}$ is a time trend over the entire investigation period and $w_{2}$ is the corresponding coefficient. In addition, $\phi$, reflects the velocity with which the variables adjust their short-term disequilibria towards a long term equilibrium, or the degree of adjustment the short run disequilibria attained relative to their long run equilibrium during the subsequent time period. Hence, $\phi$ is commonly called the coefficient of adjustment.

Mathematically, the sign of the EC term should be positive if changes in the dependent variable are greater than its average value. Put differently, $\Delta Y_{t}$ tends to move downwards to converge to the path of equilibrium in the long run. Conversely, the EC term should exhibit a positive sign if $\Delta Y_{t}$ is below its average value, and $\phi$ should therefore be negative in order to drive the dependent variable upward over time (Ghosh, 1995). To sum up, the EC term is designed in such a way that $Y$ is "pushed" back towards the position of long run equilibrium. 
As elucidated above, the ECM should be employed to conduct the Granger causality test if the variables in question are cointegrated in the long run. Under the framework of ECM, short and long run causality should be separately examined. Technically, the Wald test can be used to test for the coefficient restriction on the first differenced terms since the coefficients $\beta_{j}$ 's measures the short-term dynamics between the variables (Toda and Phillips, 1993). On the other hand, long term causality between the variables could be determined by testing for the coefficient restriction on the EC term. The null hypothesis of non-Granger causality should not be rejected if $\phi$ does not statistically deviate from zero. Conversely, $\phi$ should be negatively signed and statistically significant if and only if a long-term Granger lead-lag relationship exists (Enders, 1995; Masih and Masih, 1997).

\section{Results}

\section{Descriptive Statistics}

The average price of within the Northern Ireland housing market equates to circa $£ 150,000$ in 2018 Q4, whereas the average rent during the same period is approximately $£ 7,700$ (Table 1). As in other regions of the U.K., the Detached sector in Northern Ireland is the smallest in terms of stock size $(n=1,489$ or $3.46 \%$ ) yet the most expensive with an average sale price of circa $£ 207,000$ and an average monthly rent of circa $£ 10,500$. The Semi-detached sector, being the second most unaffordable in terms of pricing, commands an average price of circa $£ 165,000$ and an average monthly rent of $£ 8,200$. The two sectors with the largest sample size and housing stock, namely Terraced $(n=18,266$ or $42.5 \%)$ and Apartment $(n=17,940$ or $41.7 \%)$ are relatively more affordable with average prices of $£ 98,469$ and $£ 130,000$ respectively. Not surprisingly, they also report the lowest average monthly rents of $£ 6,800$ and $£ 7,900$. Table 1 provides some descriptive statistics of the four property types as in 2018 Q4.

[INSERT TABLE 1]

As evidenced in Figure 1, the P-t-R ratios at the aggregate level and for the distinct property types show some quite disparate trends over the investigation period. In line with previous UK-based research findings (e.g. Lo et al., 2021) the Detached submarket has been consistently demonstrating the highest price-to-rent ratios relative to those of the other submarkets, hovering in the region of $20-36$ for most of the quarters examined. Pertinently, this is due primarily to the fact that the Detached sector is buyerdominated. Nonetheless, the detached sector displays more pronounced volatility over the time series and shows an increase in the P-t-R ratio from 24.75 in Q1 2014 to 36.88 in Q4 2015 in line with wider macroeconomic cyclicity. On the contrary, the two renters-driven submarkets, namely Terrace and Apartments, display the lowest ratios throughout the sample period. It is also discernible that the terrace sector displays a relatively consistent trend around a P-t-R of 14 over the period and displays the lowest 
P-t-R ratio overall. Semi-detached exhibits a more consistent trend similar to that of the aggregate market between Q1 2014 to Q1 2017, with price-to-rent ratios fluctuating between 20 and 24. Similarly, the Semi-detached segment of the housing market exhibits a consistent trend, where it displays more variability until Q1 2018 where it also stays constant to Q4 2018.

\section{[INSERT FIGURE 1]}

Correlations between the various segments are undertaken to examine the interrelationships amongst the price-to-rent ratios of the submarkets. Most noteworthy is the negative correlations between Apartment and all other submarkets. For instance, the correlation coefficient between Apartments and Detached is -0.48 , inferring that the two sectors tend to move in opposite directions in terms of their price-to-rent dynamics over time. On the other hand, Detached and Semi-detached reveal a moderately positive coefficient $(\mathrm{r}=0.36)$, seemingly suggest that there is a weak positive temporal association between their respective price-to-rent ratios.

Further exploration of the correlations between the P-t-R ratios and the macroeconomic variables uncovers some preliminary empirical findings (See Table 2). First and foremost, the Northern Ireland housing market at the aggregate level responds to the macroeconomic factors differentially, with the USD/GBP being the most positively correlated to the P-t-R ratio of the market ( $\mathrm{r}=0.37)$, followed by EUR/GBP ( $\mathrm{r}=0.26)$. This seems to suggest that real estate in Northern Ireland is quite sensitive to the foreign exchange market, perhaps partially due to the massive depreciation of the British pound sterling after the Brexit vote in 2016. Secondly, the housing market is to a large extent quite compartmentalised by property type as evidenced by the varying degrees of correlation to the macroeconomic attributes, indicating that there is divergence in how each housing submarket responds to macroeconomic forces. For example, the Detached sector is highly positively correlated to the two exchange rate variables but negatively correlated to the stock market variable and money supply variables. The Terrace sector is more responsive, albeit negatively, to the movement of inflation rate as indicated by the negative correlation coefficient $(\mathrm{r}=-0.40)$. The Apartment segment of the market does not display any sizeable associations with most macroeconomic variables except the NICEI ( $r=0.30)$. Accordingly, we shed further light on the interactions between the P-t-R dynamics across property types and the macroeconomic climate using Cointegration and Granger Causality tests.

[INSERT TABLE 2] 


\section{Results of ADF Tests and Cointegration Tests}

As pointed out by Hamilton (1994), if a time series displays a time trend, whether it is stochastic or deterministic, consideration should be given around incorporating an intercept term and a time trend. Given that the time series under investigation appears to contain a time trend and contain non-zero means based on our initial graphical analysis, we therefore include both a constant term as well as a time trend within the analysis. The key results of the ADF tests are reported in Table 3. Most of the time series are stationary at level or at first difference at the 5\% significant level except for CPI and M3, which contain no unit root only when they are treated as $I(2)$. Consequently, in the following sections we apply differencing according to the stationarity of the time series, which is in line with Granger and Newbold (1974).

\section{[INSERT TABLE 3]}

The results of the Johansen cointegration tests on each pair of P-t-R variables and macroeconomic indicators are reported in Figure $6^{3}$ with a number of interesting findings observed. Inflation is only cointegrated with the P-t-R ratio within the Semi-detached segment of the market. Second, whilst all property types are cointegrated with the FTSE, the aggregate level P-t-R ratio is not. Similarly, the results on the exchange rate variables reveal some contrasting empirical observations. For example, EUR/GBP display a long-term cointegration relationship with all housing segments except for the aggregate level and Terrace sector; with USD/GBP cointegrated with all housing types except for Detached.

Money supply (M3) seems to be a more useful indicator in explaining the pricing dynamics of the NI housing market than $M 2$. The former is cointegrated with all housing types, whereas the latter is only moving in tandem with the Detached market. Equally, all P-t-R ratios exhibit a long-term cointegration relationship with mortgage interest rates (MIR), the NI Composite Economic Index (NICEI) and the construction related Economic Index $\mathrm{NICEI}_{c}$. Lastly, the analysis shows the P-t-R ratio is generally progressing concurrently with the amount of private housing investment growth but not the counterpart of total housing investment, given that the trace statistic is statistically significant for $\mathrm{NH}_{\mathrm{p}}$ but not for $\mathrm{NH}_{\mathrm{a}}$. In addition, the price-to-rent movement of the Detached sector appears to be insensitive to both housing investment variables in terms of cointegration as depicted by the trace test statistics (Table 4).

\section{[INSERT TABLE 4]}

\footnotetext{
${ }^{3}$ We employ the $95 \%$ confidence interval using the trace statistics to determine whether a cointegration relationship exists.
} 
The results of the cointegration analysis provides the methodological basis for the subsequent Granger causality tests: if a given pair of variables are cointegrated in the long-run, then an ECM causality approach is applied, otherwise the lead-lag relationship is examined within a non-ECM framework. Table 5 depicts the results of the Granger Causality tests with the Chi-square statistics and $p$-value reported (in parenthesis) for each pair of time series investigated - based on the $95 \%$ confidence level. The findings reveal that the macroeconomic variables are causally correlated with the P-t-R ratios of the different housing sectors in a relatively disparate fashion. For instance, Inflation Granger-causes only the Semi-detached submarket (in the long-run) but not the other market segments. The stock market variable, FTSE, seems to lag behind the P-t-R ratio across the various housing types, but not at the aggregate level. As regards to the pricing dynamics relative to the exchange rates, EUR/GDP seems to be, in a Granger sense, a driver for the Detached and Apartment submarkets in the long-term. However, it is interesting to note that the P-t-R ratio of the Semi-detached sector indeed leads the exchange rate variable. On the other hand, the USD appears to Granger-cause the P-t-R of the aggregate market as well as those of the Semi-detached and Apartment sectors in the long-run, with short-term lead-lag relationships further empirically confirmed for the latter two sectors. Indeed, the Apartment sector shows a bi-directional Granger causal interaction with USD/GBP over the long-run.

Similar to the results for cointegration, M3 seems to display a stronger association with the housing market in terms of Granger causation than M2. For instance, the findings indicate that M3 dictates the P-t-R movements of both Semi-detached and Terrace types, whilst the opposite causation is observed at the overall (aggregate) market level in the long-term. It is further noteworthy that mortgage interest rates, IRs, Granger-causes the P-t-R interactions of Semi-detached, Terrace and Apartments in both the short- and long-term, yet it is Granger-caused by the Detached sector. The causality tests also confirm that the productivity of the construction sector, as proxied by NICEI (construction) is a lagging indicator of the P-t-R ratio, in either short or long-term, or both, across all housing submarkets. Last but not least, the results show that the volume of new private housing investment displays a strong and consistent Granger-causal relationship at the aggregate level and with all house types except for Detached with respect to their P-t-R ratios, with the causal link running from the former to the latter. On the other hand, total new private investment is only interlinked with the Terrace submarket, with the latter Granger-causing the former in both the short- and long-term.

[INSERT TABLE 5] 


\section{Discussion of results}

The empirical analysis has provided some noteworthy and important insights into the interaction between housing P-t-R dynamics and macroeconomic fundamentals of various segments of the economy, including the financial sector, construction industry and the foreign exchange market. First and foremost, the long-term temporal association between the inflation rate and the P-t-R ratio does not seem to be significant across the Northern Ireland housing market, albeit it is notable that some evidence of the Semi-detached sector being Granger-caused by CPI is observed. Further exploration of the data reveals that the quarterly year-on-year inflation rate declines from $0.8 \%$ to $0.2 \%$ during the sample period whilst the aggregate P-t-R ratio hovers narrowly between 20 to 24 during the same period. It can therefore be inferred that the housing market exhibits, in terms of affordability, a different growth trajectory than that of the general market of goods and services.

Existing research has empirically demonstrated that the stock market and housing market are tied (Green, 2002; Ludwig and Sløk, 2004; Kakes and Van Den End, 2004; Apergis et al., 2014; Kishor and Morely, 2015). Our findings reveal the FTSE index to be highly cointegrated with the P-t-R ratios of the different housing types, but interestingly, not with that of the aggregate housing market. Furthermore, it is evident that only certain submarkets such as the Semi-detached and Terraced Grangercause the movement of the stock market, which further signals the housing market in Northern Ireland seems to be highly compartmentalised by property type in terms of pricing behaviour. The findings also show that the foreign exchange market is found to play a crucial role in dictating the P-t-R dynamics of the property market. Indeed, the results established evidence, for example, that EUR/GBP Grangercauses the P-t-R movements for Detached and Apartments, and USD/GBP Granger-causes Terrace houses and Apartments in the long-run. Indeed, the ECM results further indicate a significant bidirectional causal relationship between USD/GBP and Apartments in the long run. This is perhaps not surprising given that the Northern Ireland housing market is, to a large degree, driven by the inflows and outflows of international investment capital, particularly FDI from Republic of Ireland. As a result of the UK's departure from the European Union in 2016, the depreciation of the British pound sterling against other major international currencies such as the USD has indeed made the Northern Ireland residential market a favourable long-term investment option for many global institutional investors and specifically private equity players looking to gain exposure, en masse, to residential direct real estate in the U.K.

The cointegration analysis further suggested that the flows of capital (monetary supply) are cointegrated with all P-t-R time series, confirming a consistent linkage between money supply and the housing market at both aggregate and submarket levels. The findings of the Granger Causality tests further demonstrated that, albeit less statistically conclusive and significant, the growth rate of money supply indeed leads the Semi-detached and Terrace sectors in the long-run, which collectively account for over half of the total stock of the housing market. This is consistent with our assumption that the effect 
stemming from the government monetary policy such as Quantitative Easing has been long lasting with the market persistently buoyed by the inflows of new capital created in a low-interest environment. The findings are also in accordance with Cronin and McQuinn (2016) who demonstrated the role of credit availability and flows to drive P-t-R ratios within the Irish market. However, it is notable that when a more narrowly defined money supply (M2) variable is used, the results of the cointegration and causality tests become considerably less significant across most of the house types examined. We attribute such difference in the results to the fact that the more expansive definition of monetary supply (M3) covers a broader spectrum of money, including institutional funds which have been one of the key drivers of the Northern Ireland property industry over the last 10 years and the sample period.

Literature demonstrating a relationship between mortgage interest sensitivity and house prices is long and extensive (Brasington and Sarama, 2008; Damen et al.,2016; Downing et al., 2005; Hubbard and Mayer, 2009; McQuinn and O'Reilly, 2008). Kishor and Morely (2015) established that house price ratios which have higher present value residual components are more sensitive to mortgage rate changes. It is also discernible from our results that there is a long-term cointegrating relationship between mortgage interest rates and all P-t-R ratios, implying that the pricing behaviour of every housing segment is strongly correlated to the lending market over a longer-time horizon. Further examination of the lead-lag relationships between the housing sectors using Granger causality techniques revealed notable insights. The P-t-R ratio of the Detached sector indicated a bi-directional Granger-causal relationship with mortgage interest rates, which in turn Granger-causes the P-t-R ratios of the other three submarkets in both the short- and long-term. This is largely in line with other previous research findings of Lo et al. (2021) which found that the Detached property sector causally leads other property types of lower strata in the price discovery process of the market. Essentially, the Detached segment, characterised by its composition of investors and homebuyers of higher purchasing power, and a longer investment planning horizons, tends to "set the tone" for other housing segments through the spill-over of pricing signals over time.

Further, our results in line with Green (1997) reveal that all P-t-R times series, are long-term cointegrated with both NICEI and NICEI (construction), seemingly suggesting that the property market, by-and-large, is moving synchronously with other sectors of the economy, in particular the construction industry. In addition, based on the results of the Granger causality tests, the P-t-R dynamics tend to Granger-cause the overall productivity of the construction market with four out of the five submarkets (including the aggregate market) exhibiting a Granger causal link running from the former to the latter. This finding, we posit, can be explained by the DiPasquale-Wheaton (DW) Model which indicates that the level of construction of new housing assets is, broadly speaking, dependent upon the prices of real estate and/or the P-t- $\mathrm{R}$ ratio. 
Last but not least, it is empirically discernible that total new private housing investment growth seems to be a more accurate indicator that explains/predicts future pricing behaviour of the housing market than the counterpart of total new housing - a finding concomitant with Kishor and Morely (2015) who found a correlation between shocks to expected rent growth, the expected housing return. More specifically, our Granger causality tests reveal that the growth in the volume of private new housing Granger-causes the P-t-R ratios of the Semi-detached, Terrace and Apartment sectors in both the shortand long-run. This finding, on first viewing, appears counter-intuitive as the increased supply of new private housing should theoretically depress price, which in turn may result in a more subdued level of prices to rents. However, it can also be argued that the elasticity of private housing supply could in practice have a larger impact on the rental market then on the sales market, especially in the context of the Northern Ireland market where recent years have witnessed a sizeable increase in the supply of apartment buildings and student accommodation. In other words, the reduction in the average rent due, for instance, to a supply shock could be greater than that of the average sales price, giving rise to a higher P-t-R ratio. This finding was also notable in the research of Cronin and McQuinn (2016) who also linked this to macroprudential policy measures and implications of constraints on LTV ratios on relative prices (purchasing versus renting) in the housing market. They found that reduced LTV ratios raise rents relative to house prices over the longer-term which they identified comprises important implications, including when a need to stimulate the rate of housing supply.

\section{Conclusions}

The behaviour of house prices and rental prices are important prognosticators for understanding housing markets, and in particular whether the pricing structure is representative of underpinning demand and supply fundamentals, if a market 'bubble' may be forming and wider social policy issues relating to housing market affordability. Accordingly, this paper has investigated the temporal relationships between the P-t-R ratio and wider macroeconomic and financial determinants within the NI housing market and further decomposed these interactions by housing type applying cointegration and causality methods.

Consistent with previous research studies, the findings within this study reveal some very distinct longand short-run relationships between macroeconomic and financial indicators and the P-t-R ratios across the various housing segments. Thus, the findings do point towards market segmentation issues, and more aptly, are in accord with the submarket hypotheses indicating that there are very distinct and subtle differences within and across housing segments of the market, each of which has very unique supply and demand fundamentals. Indeed, the findings emanating out of this study show that the P-t-R ratio can be used as an early measure for establishing the effects of macroprudential policy changes and how these may manifest across housing tiers and quality, and further act as a signal for preventing or at least mitigating future irrational price cyclicity and answering more a fundamental 'buy or rent' question for many considering or attempting to access the housing market. 
The results also exhibit monetary supply, foreign exchange market 'arbitrage' and the stock market to be important drivers of the P-t-R ratio, with price to rent movements seemingly tied, or are in tandem, with the overall economy, particularly with the construction sector. These insights serve to inform housing and economic policy and macroprudential policy design, principally within lending policy, and the effect of regulatory interventions and further enhance the understanding of the P-t-R ratio on housing market structure and dynamics.

In terms of valuation practice, standardised appraisal methods, namely the comparable sales or replacement cost approaches could perhaps use the P-t-R ratio and indeed rental pricing behaviour and signals to further inform the undertaking of appraisals, as these methods are not designed to identify speculative pressures within the housing market and simultaneously provide evidence of current market rents. Equally, the results provide a basis for enhanced understanding of the market in terms of information efficiency and arbitrage strategies for real estate investors, through the comparison of the P-t-Rs of different property types cross sectionally and temporally.

Future research can shed light on the interactions of the P-t-R ratio in a spatial sense to test the variation and effects of changes in the P-t-R ratio horizontally across housing markets to garner more insight into socio-economic and demographic market structures to present enhanced micro-level Spatio-temporal understanding of the P-t-R ratio. 


\section{References}

Apergis, N., Simo-Kengne, B. and Gupta, R. (2014), "The long-run relationship between consumption, house prices, and stock prices in South Africa: evidence from provincial-level data", Journal of Real Estate Literature, Vol. 22 No. 1, pp. 83-99.

Begley, J., Loewenstein, L. and Willen, P. S. (2019), The price-rent ratio during the boom and bust: measurement and implications", Federal Reserve Bank of Boston and NBER, pp. 1-37.

Benerjee, A., Doladlo, J. J., Galbraith, J. W. and Hendry, D. F. (1993), "Cointegration, error correction, and the econometric analysis of non-stationary data", Oxford University Press, Oxford, U.K., pp. 69-84.

Borgersen, T. A. (2020), "Loan-to-value and the price-rent ratio", Journal of European Real Estate Research, Vol. 13 No. 2, 2020, pp. 149-159.

Bracke, P. (2015), "Housing prices and rents: microevidence from a matched data set in central London", Real Estate Economics, Vol. 43 No. 2, pp. 403-431

Brasington, D. M. and Sarama Jr, R. F. (2008), "Deed types, house prices and mortgage interest rates", Real Estate Economics, Vol. 36 No. 3, pp. 587-610.

Byrne, M. and Norris, M. (2018), "Procyclical social housing and the crisis of Irish Hhousing policy: marketisation, social housing and the property boom and bust", Housing Policy Debate, Vol. 28 No. 1, pp. 50-63.

Campbell, J. Y. and Shiller, R. (1988), "The dividend price ratio and expectations of future dividends and discount factors", The Review of Financial Studies, Vol. 1 No. 3, pp. 195-288.

Campbell, S. D., M. Davis., J. G. Gallin and R. F. Martin. (2009), "What moves housing markets: a variance decomposition of the rent-price ratio", Journal of Urban Economics, Vol. 66 No. 2, pp. $90-102$.

Chan, H.L. and Woo, K.Y. (2013), "Studying the dynamic relationships between residential property prices, stock prices and GDP: lessons from Hong Kong", Journal of Housing Research, Vol. 22 No. 1, pp. 75-89.

Clark, S. and Lomax, N. (2019), "Rent/price ratio for English housing sub-markets using matched sales and rental data", American Real Estate Association, pp. 1-12.

Colwell, P. F. (2002), Tweaking the DiPasquale- Wheaton Model, Journal of Housing Economics, Vol. 11 No. 1, pp. 24-39.

Coulson, N. E. and Kim, M. S. (2000), "Residential investment, non-residential investment and GDP, Real Estate Economics", Vol. 28 No. 2, pp. 233-247.

Cronin, D. and McQuinn, K. (2016), "Credit availability, macroprudential regulations and the house price-to-rent ratio", Journal of Policy Modeling, Vol. 38 No. 5, pp. 971-984.

Damen, S., Vastmans, F. and Buyst, E. (2016), "The effect of mortgage interest deduction and mortgage characteristics on house prices", Journal of Housing Economics, Vol. 34, pp. 15-29.

Dickey, D. A., Jansen, D. W. and Thornton, D.L. (1991), "A primer on cointegration with and application to money and income", Federal Reserve Bank of St. Louis Review, March/April, pp. $58-79$.

Dipasquale, D. and Wheaton, W. C. (1992), "The markets for real estate assets and space: a conceptual framework", Real Estate Economics, Vol. 20, 181-198.

Downing, C., Stanton, R. and Wallace, N. (2005), "An empirical test of a two-factor mortgage valuation model: how much do house prices matter?", Real Estate Economics, Vol. 4, pp. 681-710.

Enders, W. (1995), Applied Econometric Time Series, Wiley, New York, USA.

Engle, R. F. and Granger, C. W. J. (1987), "Cointegration and error correction: representation, estimation and testing", Econometrica, Vol. 55 No. 2, pp. $251-276$.

Feng-jun, W. W. L. Z. (2011), "Urbanization and house price-to-rent ratio: based on panel data of 35 large or medium cities", Finance and Trade Research, Vol. 5.

Fisher, I. (1930), The theory of interest as determined by impatience to spend income and opportunity to invest it, New York, the Macmillan Company.

Ghosh, A. (1995), "The hedging effectiveness of ECU futures contracts: forecasting evidence from an error correction model", The Financial Review, Vol. 30 No. 3, pp. 567-581.

Gilbukh, S., Haughwout, A. and Tracy, J. (2017), "The price to rent ratio: a macroprudential application", November, Vol. 24. 
Granger, C. W. J. (1988), "Some recent developments in a concept of causality", Journal of Econometrics, Vol. 39 No. 1-2, 199-211.

Granger, C. W. J. and Newbold, P. (1974), "Spurious regressions in econometrics", Journal of Econometrics, Vol. 2 No. 2, pp. 111-120.

Granziera, E. and Kozicki, S. (2015), "House price dynamics: fundamentals and expectations", Journal of Economic Dynamics and Control, Vol. 60, pp. 152-165.

Green, R. K. (1997), "Follow the leader: how changes in residential and non-residential investment predict changes in GDP", Real Estate Economics, Vol. 25 No. 2, pp. 253-270.

Green, R. K. (2002), "Stock prices and house prices in California: new evidence of a wealth effect?", Regional Science and Urban Economics, Vol. 32 No. 6, pp. 775-783.

Hill, R. J. and Syed, I. A. (2016), "Hedonic price-rent ratios, user cost, and departures from equilibrium in the housing market", Regional Science and Urban Economics, Vol. 56, pp. 60-72.

Hubbard, R. G. and Mayer, C. J. (2009), "The mortgage market meltdown and house prices", The BE Journal of Economic Analysis and Policy, Vol. 9 No. 3, Article 8.

Hulse, K. and Yates, J. (2017), "A private rental sector paradox: unpacking the effects of urban restricting on housing market dynamics", Housing Studies, Vol. 21 No. 3, pp. 253-270.

Johansen, S. (1991), Estimation and Hypotheses Testing of Co-integration Vectors in Gaussian Vector Autoregressive Models, Econometrica, Vol. 59 No. 6, pp. 1551 - 1580.

Johansen, S. (1995), Likelihood-based Inference in Cointegrated Vector Autoregressive Models, Oxford University Press, Oxford, U.K.

Kakes, J. and Van Den End, J. W. (2004), "Do stock prices affect house prices? Evidence for the Netherlands", Applied Economics Letters, Vol. 11 No. 12, pp.741-744.

Kim, T. and H. Lim. (2014), "Understanding the Irish price-rent ratio: an unobserved component approach", Applied Economics Letters, Vol. 21 No. 12., pp. 836-841.

Kishor, N. K. and Morley, J. (2015), "What factors drive the price-rent ratio for the housing market? A modified present-value analysis", Journal of Economic Dynamics and Control, Vol. 58, pp. 235-249.

Lo, D., McCord, M., McCord, J., Davis, P. and Haran, M. (2021), "Rent or buy, what are the odds?: Analysing the price-to-rent ratio for housing types within the Northern Ireland housing market", International Journal of Housing Markets and Analysis (Forthcoming).

Ludwig, A. and Sløk, T. (2004), "The relationship between stock prices, house prices and consumption in OECD countries". Topics in Macroeconomics, Vol. 4 No. 1.

Masih, A. M. M. and Masih, R. (1997), "On the temporal causal relationship between energy consumption, real income, and prices: some new evidence from Asian-energy dependent NICs based on multivariate cointegration / vector error correction approach", Journal of Policy Modeling, Vol. 19 No. 4, pp. 417-440.

McCord, M., Lo, D., McCord, J., Davis, P. and Haran, M. (2019), "Measuring the cointegration of housing types in Northern Ireland", Journal of Property Research, Vol. 36 No. 4, pp. 343-366.

McQuinn, K., and O'Reilly, G. (2008), "Assessing the role of income and interest rates in determining house prices", Economic Modelling, Vol. 25 No. 3, pp. 377-390.

Muellbauer, J. and Murphy, A. (1997), "Booms and bursts in the UK housing market", The Economic Journal, Vol. 107 No. 445, pp. 1701-1727.

Rae, J. (1834), "Statement of some new principles on the subject of political economy", McMaster University Archive for the History of Economic Thought.

Sommer, K., Sullivan, P. and Verbrugge, R. (2010), "Run-up in the house price-rent ratio: how much can be explained by fundamentals?", US Department of Labor, Bureau of Labor Statistics, Office of Prices and Living Conditions.

Thomas, R. L. (1997), Modern Econometrics: An Introduction. Addison-Wesley, Wokingham, U.K., pp. 378-379.

Toda, H. and Phillips, P. (1993), "Vector autoregressions and causality", Econometrica, Vol. 61 No. 6, pp. $1367-1394$.

Wu, F. X. and Jiang, F. Z. (2012), "Price-to-rent ratio housing price-to-income ratio and real estate market regulation: An empirical analysis based on the comparison between regional market differences", Contemporary Finance and Economics, Vol. 6, pp. 80-88. 
Tables and Figures

Table 1: Descriptive statistics of the four property types

\begin{tabular}{lcccc}
\hline Property Type & $\begin{array}{c}\text { Average Price } \\
(\mathfrak{(})\end{array}$ & $\begin{array}{c}\text { Average Rent } \\
(\mathfrak{f})\end{array}$ & Percent & $\mathrm{N}$ \\
\hline Detached & 207,478 & 10,542 & 3.46 & 1,489 \\
Semi-detached & 165,227 & 8,194 & 12.3 & 5,278 \\
Terrace & 98,469 & 6,852 & 42.5 & 18,266 \\
Apartment & 130,249 & 7,904 & 41.7 & 17,940 \\
All & 150,890 & 7,723 & 100 & 42973 \\
\hline
\end{tabular}

Table 2: Correlation between the P-t-R and the macroeconomic variables

\begin{tabular}{lccccc}
\hline & \multicolumn{5}{c}{ Price to Rent Ratio } \\
\hline & All & Detached & $\begin{array}{c}\text { Semi- } \\
\text { detached }\end{array}$ & Terraced & Apartment \\
\hline Inflation (CPI) & -0.18 & -0.09 & 0.07 & -0.40 & -0.13 \\
FTSE & -0.06 & -0.43 & -0.04 & 0.10 & -0.14 \\
EUR/GBP & 0.26 & 0.43 & 0.00 & 0.05 & -0.09 \\
USD/GBP & 0.37 & 0.61 & 0.30 & 0.05 & 0.02 \\
M2 & -0.20 & -0.36 & -0.10 & 0.00 & 0.09 \\
M3 & -0.22 & -0.34 & -0.12 & 0.01 & -0.02 \\
Mortgage interest rate ${ }^{\mathrm{a}}$ (MIR) & 0.09 & 0.22 & 0.11 & -0.02 & -0.06 \\
NICEI & -0.24 & -0.39 & -0.14 & -0.04 & 0.30 \\
NICEI (construction) & -0.03 & -0.27 & 0.10 & 0.10 & 0.16 \\
Total new housing investment & -0.11 & -0.24 & -0.03 & 0.08 & 0.06 \\
Total new pri. housing investment & -0.08 & -0.21 & 0.01 & 0.10 & 0.03 \\
\hline Semi-detached & & 0.36 & & & \\
Terraced & & 0.10 & 0.25 & & \\
Apartment & -0.48 & -0.29 & -0.09 & \\
\hline
\end{tabular}

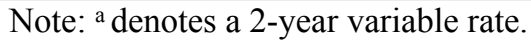

Table 3: Results of Augmented Dickey Fuller tests

\begin{tabular}{lll}
\hline Description & Variable & Stationary* \\
\hline Aggregate price to rent ratio & $P R_{A}$ & At first difference \\
Price to rent ratio of the detached submarket & $P R_{d}$ & At first difference \\
Price to rent ratio of the semi-detached submarket & $P R_{S}$ & At first difference \\
Price to rent ratio of the terraced submarket & $P R_{t}$ & At first difference \\
Price to rent ratio of the apartment submarket & $P R_{a}$ & At first difference \\
Inflation rate (CPI) & CPI & At second difference \\
FTSE Index 100 & FTSE & At first difference \\
Exchange rate of EUR/GBP & EUR/GBP & At level \\
Exchange rate of EUR/USD & EUR/USD & At first difference \\
Growth rate of M2 money supply & M2 & At first difference \\
Growth rate of M3 money supply & M3 & At second difference \\
2-year variable mortgage interest rate & MIR & At level \\
NICEI Index & NICEI & At first difference \\
NICEI Construction Index & $N I C E I_{c}$ & At first difference \\
Total new housing growth & $N H_{t}$ & At level \\
Total new private housing growth & $N H_{p}$ & At level \\
\hline
\end{tabular}

$*$ Determined by the $5 \%$ statistical level. Full results are available upon request. 
Table 4: Results of Cointegration Tests

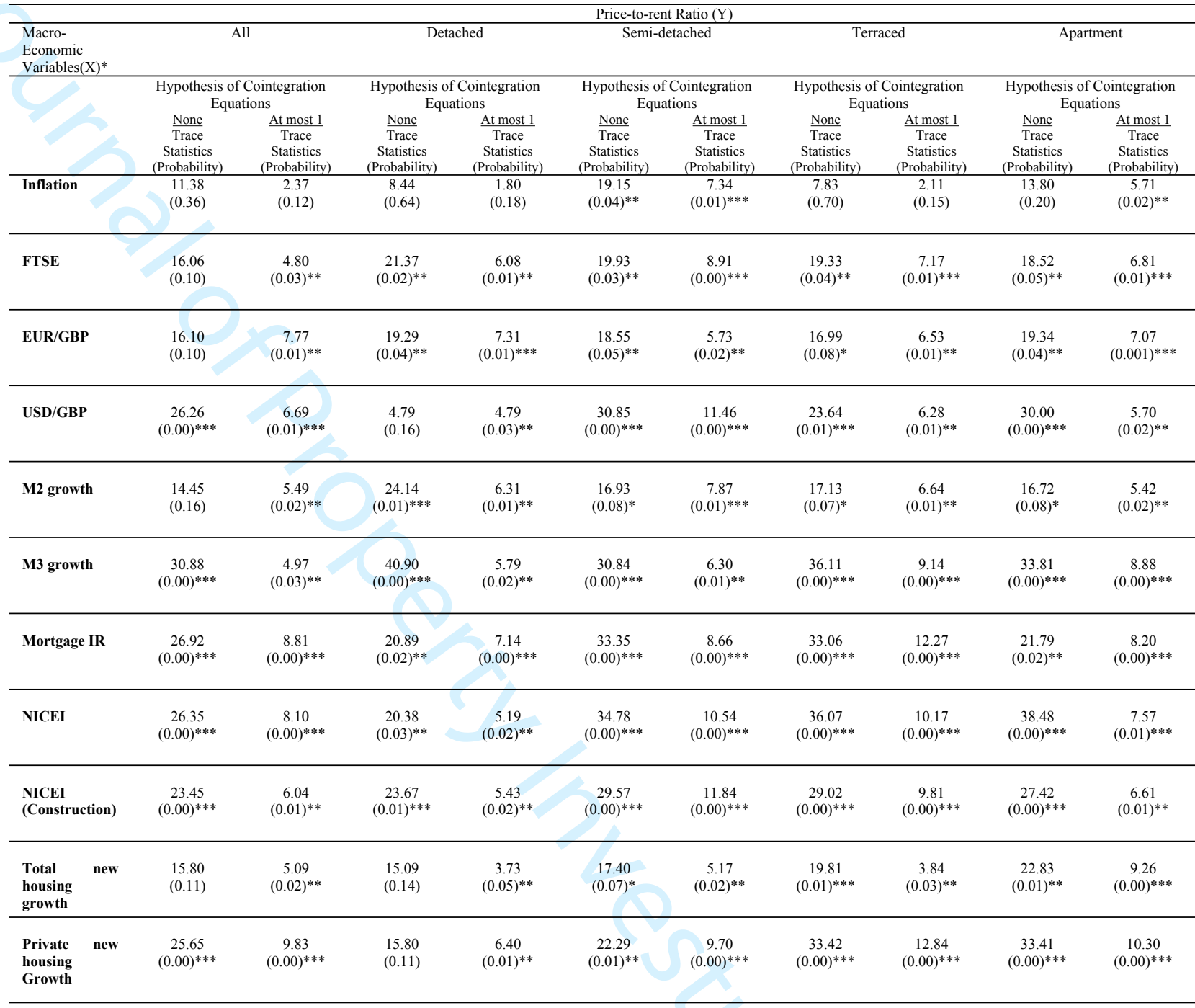

Note: $* * *$ denotes $1 \%$ statistical sig.; $* * 5 \%$ sig.; $* 10 \%$ sig. Full results are available upon request. 
Table 5: Results of Granger Causality Tests

\begin{tabular}{|c|c|c|c|c|c|c|c|c|c|c|}
\hline \multirow{2}{*}{$\begin{array}{l}\text { Macro- } \\
\text { Economic } \\
\text { Variables }(\mathrm{X})^{*} \\
\end{array}$} & \multicolumn{10}{|c|}{ Price-to-rent Ratio $(\mathrm{Y})$} \\
\hline & \multicolumn{2}{|c|}{ Aggregate } & \multicolumn{2}{|c|}{ Detached } & \multicolumn{2}{|c|}{ Semi-detached } & \multicolumn{2}{|c|}{ Terraced } & \multicolumn{2}{|c|}{ Apartment } \\
\hline & $\begin{array}{l}\text { Short -term } \\
\text { Chi sq. } \\
\text { (Prob) }\end{array}$ & $\begin{array}{l}\text { Long -term } \\
\text { t-statistic } \\
\text { (Prob) }\end{array}$ & $\begin{array}{l}\text { Short -term } \\
\text { Chi sq. } \\
\text { (Prob) }\end{array}$ & $\begin{array}{l}\text { Long -term } \\
\text { t-statistic } \\
\text { (Prob) }\end{array}$ & $\begin{array}{l}\text { Short -term } \\
\text { Chi sq. } \\
\text { (Prob) }\end{array}$ & $\begin{array}{l}\text { Long -term } \\
\text { t-statistic } \\
\text { (Prob) }\end{array}$ & $\begin{array}{l}\text { Short -term } \\
\text { Chi sq. } \\
\text { (Prob) }\end{array}$ & $\begin{array}{l}\text { Long -term } \\
\text { t-statistic } \\
\text { (Prob) }\end{array}$ & $\begin{array}{l}\text { Short -term } \\
\text { Chi sq. } \\
\text { (Prob) }\end{array}$ & $\begin{array}{l}\text { Long -term } \\
\text { t-statistic } \\
\text { (Prob) }\end{array}$ \\
\hline \multicolumn{11}{|l|}{ Inflation } \\
\hline $\mathrm{X}->\mathrm{Y}$ & $\begin{array}{c}2.83 \\
(0.24)\end{array}$ & - & $\begin{array}{c}3.14 \\
(0.21)\end{array}$ & - & $\begin{array}{l}2.76 \\
(0.25)\end{array}$ & $\begin{array}{c}-2.55 \\
(0.03)^{* *}\end{array}$ & $\begin{array}{c}2.47 \\
(0.29)\end{array}$ & - & $\begin{array}{c}0.33 \\
(0.85)\end{array}$ & - \\
\hline $\mathrm{Y} \rightarrow \mathrm{X}$ & $\begin{array}{c}0.08 \\
(0.96) \\
\end{array}$ & - & $\begin{array}{r}1.76 \\
(0.41) \\
\end{array}$ & - & $\begin{array}{r}3.28 \\
(0.19) \\
\end{array}$ & $\begin{array}{l}-1.30 \\
(0.23) \\
\end{array}$ & $\begin{array}{r}1.65 \\
(0.44) \\
\end{array}$ & - & $\begin{array}{l}1.07 \\
(0.58)\end{array}$ & - \\
\hline \multicolumn{11}{|l|}{ FTSE } \\
\hline$X->Y$ & $\begin{array}{c}1.56 \\
(0.46)\end{array}$ & - & $\begin{array}{c}1.89 \\
(0.39)\end{array}$ & $\begin{array}{c}0.99 \\
(0.35)\end{array}$ & $\begin{array}{c}3.83 \\
(0.15)\end{array}$ & $\begin{array}{l}-1.69 \\
(0.13)\end{array}$ & $\begin{array}{l}1.27 \\
(0.53)\end{array}$ & $\begin{array}{l}-1.20 \\
(0.27)\end{array}$ & $\begin{array}{c}1.80 \\
(0.41)\end{array}$ & $\begin{array}{l}-1.70 \\
(0.13)\end{array}$ \\
\hline $\mathrm{Y}->\mathrm{X}$ & $\begin{array}{c}1.25 \\
(0.54) \\
\end{array}$ & - & $\begin{array}{c}11.16 \\
(0.00)^{* * *}\end{array}$ & $\begin{array}{c}4.94 \\
(0.00)^{* * *}\end{array}$ & $\begin{array}{r}4.08 \\
(0.13) \\
\end{array}$ & $\begin{array}{c}-2.62 \\
(0.03)^{* *}\end{array}$ & $\begin{array}{c}16.33 \\
(0.00)^{* * *}\end{array}$ & $\begin{array}{c}-3.68 \\
(0.01)^{* * *}\end{array}$ & $\begin{array}{c}4.00 \\
(0.14) \\
\end{array}$ & $\begin{array}{c}2.83 \\
(0.02)^{* *}\end{array}$ \\
\hline \multicolumn{11}{|l|}{ EUR/GBP } \\
\hline $\mathrm{X}->\mathrm{Y}$ & $\begin{array}{c}2.65 \\
(0.30)\end{array}$ & 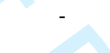 & $\begin{array}{c}0.96 \\
(0.62)\end{array}$ & $\begin{array}{c}-2.74 \\
(0.02)^{* *}\end{array}$ & $\begin{array}{c}1.07 \\
(0.59)\end{array}$ & $\begin{array}{l}-1.52 \\
(0.16)\end{array}$ & $\begin{array}{c}1.37 \\
(0.50)\end{array}$ & - & $\begin{array}{c}1.19 \\
(0.55)\end{array}$ & $\begin{array}{c}-2.19 \\
(0.05)^{* *}\end{array}$ \\
\hline $\mathrm{Y}->\mathrm{X}$ & $\begin{array}{c}0.27 \\
(0.87) \\
\end{array}$ & & $\begin{array}{c}0.12 \\
(0.94) \\
\end{array}$ & $\begin{array}{c}0.28 \\
(0.79) \\
\end{array}$ & $\begin{array}{c}1.13 \\
(0.57) \\
\end{array}$ & $\begin{array}{c}-2.46 \\
(0.03)^{* *}\end{array}$ & $\begin{array}{c}0.09 \\
(0.96) \\
\end{array}$ & - & $\begin{array}{c}1.45 \\
(0.48) \\
\end{array}$ & $\begin{array}{c}1.47 \\
(0.17) \\
\end{array}$ \\
\hline \multicolumn{11}{|l|}{ USD/GBP } \\
\hline$X->Y$ & $\begin{array}{l}4.15 \\
(0.13)\end{array}$ & $\begin{array}{l}-2.61 \\
(0.03)^{* *}\end{array}$ & $\begin{array}{c}1.05 \\
(0.59)\end{array}$ & - & $\begin{array}{c}3.15 \\
(0.21)\end{array}$ & $\begin{array}{c}-1.97 \\
(0.08)^{*}\end{array}$ & $\begin{array}{c}7.52 \\
(0.02)^{* *}\end{array}$ & $\begin{array}{c}-3.05 \\
(0.01)^{* * * *}\end{array}$ & $\begin{array}{c}10.52 \\
(0.01)^{* * *}\end{array}$ & $\begin{array}{c}-3.61 \\
(0.01)^{* * *}\end{array}$ \\
\hline $\mathrm{Y}->\mathrm{X}$ & $\begin{array}{r}0.24 \\
(0.89) \\
\end{array}$ & $\begin{array}{c}0.91 \\
(0.39) \\
\end{array}$ & $\begin{array}{r}1.50 \\
(0.47) \\
\end{array}$ & - & $\begin{array}{c}4.44 \\
(0.11) \\
\end{array}$ & $\begin{array}{c}2.09 \\
(0.07)^{*} \\
\end{array}$ & $\begin{array}{c}0.07 \\
(0.93) \\
\end{array}$ & $\begin{array}{c}0.01 \\
(0.15) \\
\end{array}$ & $\begin{array}{c}4.23 \\
(0.12) \\
\end{array}$ & $\begin{array}{c}-2.38 \\
(0.04)^{* *} \\
\end{array}$ \\
\hline \multicolumn{11}{|l|}{ M2 growth } \\
\hline$X->Y$ & $\begin{array}{c}2.86 \\
(0.24)\end{array}$ & - & $\begin{array}{c}0.66 \\
(0.72)\end{array}$ & $\begin{array}{c}0.53 \\
(0.61)\end{array}$ & $\begin{array}{c}1.14 \\
(0.57)\end{array}$ & - & $\begin{array}{c}0.03 \\
(0.98)\end{array}$ & - & $\begin{array}{c}5.65 \\
(0.06) *\end{array}$ & - \\
\hline $\mathrm{Y}->\mathrm{X}$ & $\begin{array}{c}0.01 \\
(0.99) \\
\end{array}$ & - & $\begin{array}{c}6.89 \\
(0.03)^{* *} \\
\end{array}$ & $\begin{array}{c}3.64 \\
(0.01) * * \\
\end{array}$ & $\begin{array}{c}0.55 \\
(0.76) \\
\end{array}$ & - & $\begin{array}{c}0.87 \\
(0.65) \\
\end{array}$ & - & $\begin{array}{c}0.92 \\
(0.63) \\
\end{array}$ & - \\
\hline \multicolumn{11}{|l|}{ M3 growth } \\
\hline $\mathrm{X}->\mathrm{Y}$ & $\begin{array}{c}2.99 \\
(0.22)\end{array}$ & $\begin{array}{l}-1.89 \\
(0.10)\end{array}$ & $\begin{array}{c}2.84 \\
(0.24)\end{array}$ & $\begin{array}{c}1.62 \\
(0.15)\end{array}$ & $\begin{array}{c}3.51 \\
(0.17)\end{array}$ & $\begin{array}{c}-2.33 \\
(0.05)^{* *}\end{array}$ & $\begin{array}{c}11.93 \\
(0.00)^{* * *}\end{array}$ & $\begin{array}{c}-3.17 \\
(0.02)^{* *}\end{array}$ & $\begin{array}{c}2.51 \\
(0.29)\end{array}$ & $\begin{array}{l}-0.65 \\
(0.53)\end{array}$ \\
\hline $\mathrm{Y}->\mathrm{X}$ & $\begin{array}{r}4.45 \\
(0.11) \\
\end{array}$ & $\begin{array}{c}-2.44 \\
(0.04)^{* *} \\
\end{array}$ & $\begin{array}{c}3.02 \\
(0.22) \\
\end{array}$ & $\begin{array}{c}3.02 \\
(0.02) * * \\
\end{array}$ & $\begin{array}{c}6.64 \\
(0.04)^{* *} \\
\end{array}$ & $\begin{array}{l}-1.96 \\
(0.09) * \\
\end{array}$ & $\begin{array}{c}1.09 \\
(0.58) \\
\end{array}$ & $\begin{array}{c}0.17 \\
(0.87) \\
\end{array}$ & $\begin{array}{r}4.28 \\
(0.12) \\
\end{array}$ & $\begin{array}{l}-1.55 \\
(0.16) \\
\end{array}$ \\
\hline \multicolumn{11}{|l|}{ Mortgage IR } \\
\hline$X->Y$ & $\begin{array}{c}2.84 \\
(0.24)\end{array}$ & $\begin{array}{l}-1.95 \\
(0.08)^{*}\end{array}$ & $\begin{array}{c}3.04 \\
(0.22)\end{array}$ & $\begin{array}{l}-1.51 \\
(0.16)\end{array}$ & $\begin{array}{c}21.77 \\
(0.00)^{* * *}\end{array}$ & $\begin{array}{c}-6.46 \\
(0.00)^{* * *}\end{array}$ & $\begin{array}{c}15.36 \\
(0.00)^{* * *}\end{array}$ & $\begin{array}{c}-4.49 \\
(0.00)^{* * *}\end{array}$ & $\begin{array}{c}6.73 \\
(0.05)^{* *}\end{array}$ & $\begin{array}{c}-3.60 \\
(0.00)^{* * *}\end{array}$ \\
\hline $\mathrm{Y}->\mathrm{X}$ & $\begin{array}{l}2.22 \\
(0.33) \\
\end{array}$ & $\begin{array}{c}1.44 \\
(0.18)\end{array}$ & $\begin{array}{c}11.86 \\
(0.00)^{* * *}\end{array}$ & $\begin{array}{c}-3.53 \\
(0.01)^{* *} \\
\end{array}$ & $\begin{array}{c}2.78 \\
(0.25) \\
\end{array}$ & $\begin{array}{c}0.15 \\
(0.89) \\
\end{array}$ & $\begin{array}{c}10.12 \\
(0.01)^{* * *}\end{array}$ & $\begin{array}{c}1.56 \\
(0.15) \\
\end{array}$ & $\begin{array}{c}6.55 \\
(0.04) * * \\
\end{array}$ & $\begin{array}{l}-1.94 \\
(0.08) *\end{array}$ \\
\hline \multicolumn{11}{|l|}{ NICEI } \\
\hline$X->Y$ & $\begin{array}{c}0.17 \\
(0.92)\end{array}$ & $\begin{array}{l}-0.23 \\
(0.83)\end{array}$ & $\begin{array}{c}2.91 \\
(0.23)\end{array}$ & $\begin{array}{l}-2.15 \\
(0.06) *\end{array}$ & $\begin{array}{c}0.43 \\
(0.81)\end{array}$ & $\begin{array}{l}-0.66 \\
(0.52)\end{array}$ & $\begin{array}{c}25.71 \\
(0.00)^{* * *}\end{array}$ & $\begin{array}{c}-5.14 \\
(0.00)^{* * * *}\end{array}$ & $\begin{array}{c}4.92 \\
(0.09) *\end{array}$ & $\begin{array}{l}-1.56 \\
(0.15)\end{array}$ \\
\hline $\mathrm{Y}->\mathrm{X}$ & $\begin{array}{c}12.42 \\
(0.00)^{* * *} \\
\end{array}$ & $\begin{array}{c}4.46 \\
(0.00)^{* * *} \\
\end{array}$ & $\begin{array}{c}0.20 \\
(0.65) \\
\end{array}$ & $\begin{array}{c}2.20 \\
(0.05) * * \\
\end{array}$ & $\begin{array}{l}1.78 \\
(0.41) \\
\end{array}$ & $\begin{array}{l}-1.48 \\
(0.17) \\
\end{array}$ & $\begin{array}{c}1.56 \\
(0.46) \\
\end{array}$ & $\begin{array}{l}-1.04 \\
(0.33) \\
\end{array}$ & $\begin{array}{c}3.84 \\
(0.15) \\
\end{array}$ & $\begin{array}{c}0.58 \\
(0.58) \\
\end{array}$ \\
\hline \multicolumn{11}{|l|}{$\begin{array}{l}\text { NICEI } \\
\text { (Construction) }\end{array}$} \\
\hline$X->Y$ & $\begin{array}{c}2.21 \\
(0.33)\end{array}$ & $\begin{array}{c}-1.62 \\
(0.14)\end{array}$ & $\begin{array}{c}0.88 \\
(0.64)\end{array}$ & $\begin{array}{l}-0.15 \\
(0.88)\end{array}$ & $\begin{array}{c}2.02 \\
(0.36)\end{array}$ & $\begin{array}{l}-0.16 \\
(0.87)\end{array}$ & $\begin{array}{c}0.94 \\
(0.62)\end{array}$ & $\begin{array}{l}-0.20 \\
(0.84)\end{array}$ & $\begin{array}{c}0.52 \\
(0.77)\end{array}$ & $\begin{array}{c}0.74 \\
(0.48)\end{array}$ \\
\hline $\mathrm{Y}>>\mathrm{X}$ & $\begin{array}{c}5.47 \\
(0.07)^{*}\end{array}$ & $\begin{array}{c}-4.47 \\
(0.00)^{* * *}\end{array}$ & $\begin{array}{c}17.8 \\
(0.00)^{* * *}\end{array}$ & $\begin{array}{c}-3.66 \\
(0.01)^{* *}\end{array}$ & $\begin{array}{c}9.63 \\
(0.01)^{* *}\end{array}$ & $\begin{array}{c}-4.56 \\
(0.00)^{* * *}\end{array}$ & $\begin{array}{c}1.38 \\
(0.50) \\
\end{array}$ & $\begin{array}{c}-4.42 \\
(0.00)^{* * *}\end{array}$ & $\begin{array}{c}7.46 \\
(0.02) * * \\
\end{array}$ & $\begin{array}{c}4.24 \\
(0.00) * * \\
\end{array}$ \\
\hline \multicolumn{11}{|c|}{$\begin{array}{ll}\text { Total } & \text { new } \\
\text { housing } & \\
\text { growth } & \end{array}$} \\
\hline $\mathrm{X}->\mathrm{Y}$ & $\begin{array}{c}3.08 \\
(0.21)\end{array}$ & - & $\begin{array}{c}3.30 \\
(0.19)\end{array}$ & - & $\begin{array}{c}0.57 \\
(0.75)\end{array}$ & & $\begin{array}{c}0.03 \\
(0.98)\end{array}$ & $\begin{array}{c}0.01 \\
(0.99)\end{array}$ & $\begin{array}{c}0.43 \\
(0.81)\end{array}$ & $\begin{array}{c}0.87 \\
(0.40)\end{array}$ \\
\hline $\mathrm{Y}->\mathrm{X}$ & $\begin{array}{c}1.25 \\
(0.54) \\
\end{array}$ & - & $\begin{array}{c}0.77 \\
(0.68) \\
\end{array}$ & - & $\begin{array}{c}1.15 \\
(0.56) \\
\end{array}$ & - & $\begin{array}{c}8.28 \\
(0.02)^{* *} \\
\end{array}$ & $\begin{array}{c}-3.98 \\
(0.00)^{* *} \\
\end{array}$ & $\begin{array}{c}1.52 \\
(0.47) \\
\end{array}$ & $\begin{array}{c}3.11 \\
(0.01)^{* *} \\
\end{array}$ \\
\hline \multicolumn{11}{|l|}{$\begin{array}{ll}\begin{array}{l}\text { Private } \\
\text { housing }\end{array} & \\
\text { Growth } & \end{array}$} \\
\hline $\mathrm{X}->\mathrm{Y}$ & $\begin{array}{c}8.91 \\
(0.01)^{* *}\end{array}$ & $\begin{array}{c}-3.98 \\
(0.00)^{* * *}\end{array}$ & $\begin{array}{l}2.27 \\
(0.31)\end{array}$ & - & $\begin{array}{c}6.40 \\
(0.04)^{* *}\end{array}$ & $\begin{array}{c}-3.62 \\
(0.00)^{* * *}\end{array}$ & $\begin{array}{c}5.92 \\
(0.05)^{* *}\end{array}$ & $\begin{array}{c}-3.26 \\
(0.01)^{* *}\end{array}$ & $\begin{array}{c}30.15 \\
(0.00)^{* * *}\end{array}$ & $\begin{array}{c}-7.15 \\
(0.00)^{* * *}\end{array}$ \\
\hline $\mathrm{Y} \rightarrow>\mathrm{X}$ & $\begin{array}{c}4.03 \\
(0.18) \\
\end{array}$ & $\begin{array}{c}-2.15 \\
(0.06)^{*}\end{array}$ & $\begin{array}{c}0.07 \\
(0.96) \\
\end{array}$ & - & $\begin{array}{c}1.12 \\
(0.57) \\
\end{array}$ & $\begin{array}{l}-0.40 \\
(0.70) \\
\end{array}$ & $\begin{array}{c}5.69 \\
(0.06)^{*} \\
\end{array}$ & $\begin{array}{c}0.15 \\
(0.88) \\
\end{array}$ & $\begin{array}{c}0.80 \\
(0.67) \\
\end{array}$ & $\begin{array}{c}0.37 \\
(0.72) \\
\end{array}$ \\
\hline
\end{tabular}

Notes: $* * *$ denotes $1 \%$ statistical significance; $* * 5 \%$ statistical significance; $* 10 \%$ statistical significance. Full results are available upon request. 
Figure 1: Price-to-rent ratios of the four property types (2014Q1 to 2018Q4)

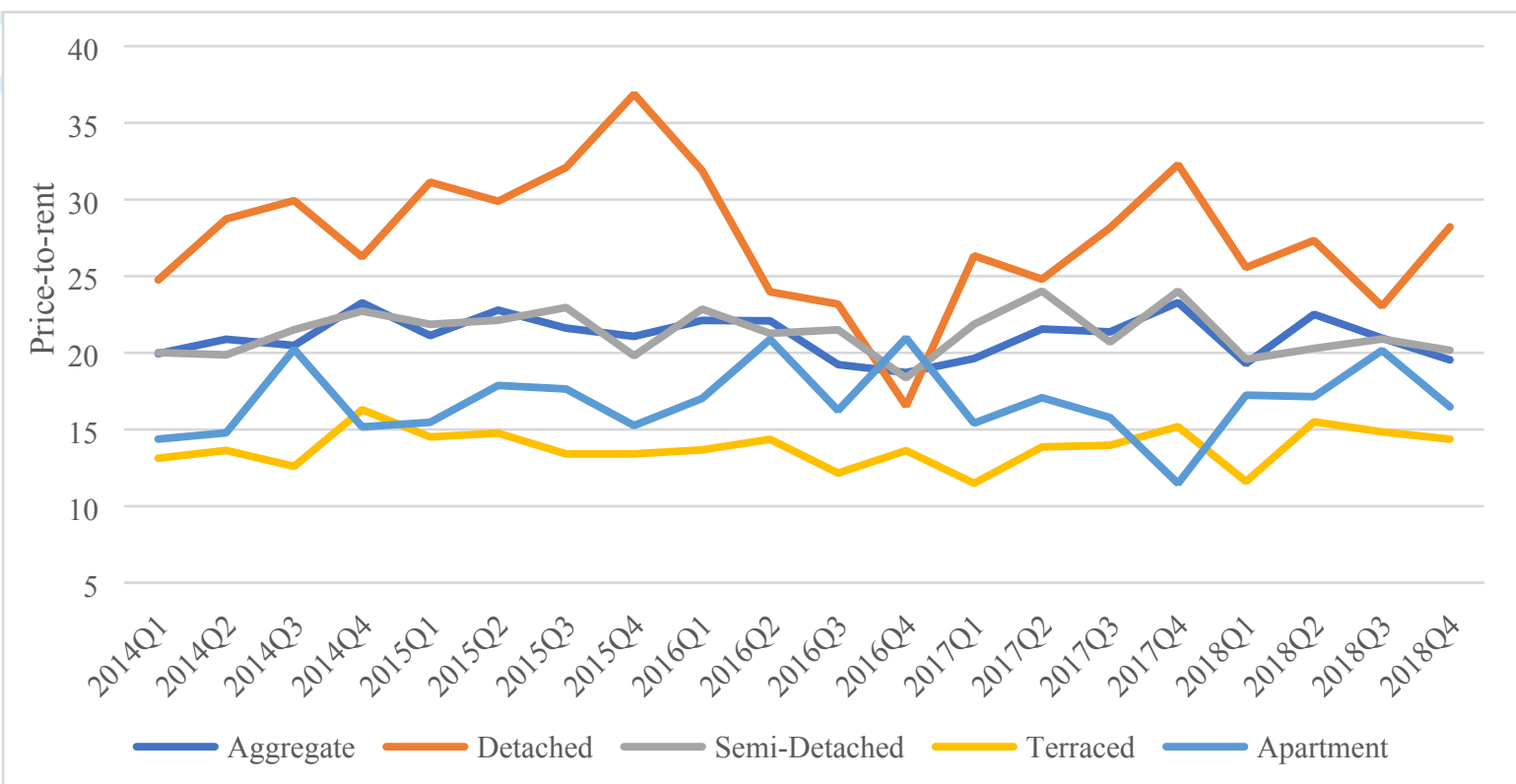


Causal Relationships between the Price-to-Rent ratio and Macroeconomic factors: A UK Perspective

\begin{abstract}
House Price-to-Rent (P-t-R) ratios are among the most widely used measure of housing market conditions. Given the theoretical and apparent bi-directional, causal relationships and imbalances between the housing market, broader economy and financial market determinants, it is important to understand the relationship between macro- and micro-economic characteristics in relation to the P-t-R ratio to enhance the understanding of housing market dynamics. This paper studies the joint dynamics and persistence of house prices and rents and examines the temporal interactions of the P-t-R ratio and economic and financial determinants. Specifically, we examine this relationship using bivariate cointegration and causality methods, initially at the aggregate position, and also across housing types within the housing market to establish whether there are subtle differences in how various housing segments react to changes in economic activity and market fundamentals. The findings reveal price switching dynamics and some very distinct long- and short-run relationships between macroeconomic and financial indicators and the P-t-R ratios across the various housing segments. The results exhibit monetary supply, foreign exchange markets and the stock market to be important drivers of the P-t-R ratio, with price to rent movements seemingly tied, or are in tandem with the overall economy, particularly with the construction sector. Indeed, the findings show that the P-t-R ratio can be used as an early measure for establishing the effects of macroprudential policy changes and how these may manifest across housing tiers and quality, and further act as a signal for preventing or at least mitigating future irrational price cyclicity. These insights serve to inform housing and economic policy and macroprudential policy design, principally within lending policy, and the effect of regulatory interventions and further enhance the understanding of the P-t-R ratio on housing market structure and dynamics.
\end{abstract}




\section{Introduction}

Housing markets are susceptible to volatility due to both endogenous and exogenous forces which cause housing market cycles and house prices to become disconnected from local market fundamentals. The most recent boom-bust cycle, the Global Financial Crisis (GFC) of 2007/8, witnessed severe house price inflation primarily driven by the expansion of monetary supply (credit) which also accelerated housing supply (Himmelberg et al., 2005; Gilbukh, et al., 2017). The housing market bust, and downward price correction witnessed a house price reversion which adversely impacted the demand for housing and housing market equilibrium. Indeed, in the immediate aftermath of the GFC, discernible policy reforms, particularly within the macroprudential and banking settings, resulted in changes within the structure of the housing market. As outlined by Cronin and McQuinn (2016), the scale of disruption experienced after 2007 in many international property markets and economies ${ }^{1}$, witnessed increased use of macroprudential policies (instruments) to tackle systemic risk by taming lending practices and/or generating buffers. As Arena et al. (2020) further highlighted, from 2013 countries within the European Union (EU) adopted various capital buffer/lender-based measures in line with the Capital Requirements Directive (CRD IV) to increase resilience and reduce housing sector imbalances, with lenders in these countries following suit with a range of measures aimed at tightening access to credit, notably reduced loan to value ratios and increased scrutiny of repayment affordability.

The introduction of these measures and the recovery and growth in house prices alongside wider economic revival has transformed the composition and structure of housing markets (Bryne and Norris, 2018). Alongside these developments, structural reforms within the private rental sector (PRS) have also been ubiquitous (globally) within housing systems due to the combined forces of policy change, financialisation, and the cyclic nature of credit markets (Lo et al., 2021), impacting upon market processes and disequilibrium between rental and housing prices and local market fundamentals (Hulse and Yates, 2017).

Accordingly, the Price-to-Rent (P-t-R) ratios offer important housing market insights (Begley et al., 2019), providing information about local real estate markets, including future market expectations and speculative market behaviour and asset pricing bubbles. In this regard, the P-t-R ratio is frequently used as an indicator for assessing housing market equilibrium (Borgersen, 2020, Kishor and Morley, 2015), with departures from equilibrium detected by comparing the P-t-R ratio with the user-cost equilibrium condition (Hill and Syed, 2016). Indeed, housing literature contends that housing market frictions such as non-convex transaction costs, tax advantages to homeownership, and higher depreciation of rental properties relative to owner-occupied properties are likely to be important determinants of housing demand and rental supply (Sommer et al., 2010) and in the determination of the P-t-R ratio. Further

\footnotetext{
${ }^{1}$ As noted by Cronin and McQuinn (2016), Hungary, Norway, Sweden, Finland and Ireland have all adopted these types of macroprudential measures.
} 
Borgersen (2020) illustrates that the context-specific effect of LTV on the P-t-R-ratio links housing markets to mortgage markets and monetary policy. These changes signal a possible deviation from the underlying market and economic fundamentals and it has long been considered that divergence from long-term values of prices in relation to rents is a cause for concern (Sommer et al., 2010).

In Northern Ireland, house prices increased more than 157\% in the two-year period 2005-2007 culminating in a house price bubble, the first of its kind in the jurisdiction. With the downturn, the residential housing market in NI witnessed the most pronounced price correction of any UK region, with house prices contracting approximately 40 percent between late 2007 and 2009, and over 50 percent by 2011. This price shock discouraged both construction of new homes and sale of existing stock, due to both perceived and actual negative equity and effectively curtailed housing supply (McCord et al., 2011). Accompanying the price correction, domestic financial institutions, akin to patterns evident across wider Europe, tightened their mortgage lending criteria. The most noticeable of these macroprudential changes was the substantial increase in depository requirements and Loan-toIncome ratios presenting a new access cost "hurdle" (McCord et al., 2011). Further, the collapse of the housing market and instability within the wider economy forced the UK government into a process of austerity which had severe connotations for the supply of housing (Schwartz, 2011).

Since late 2012, the rather uneven recovery of house prices began to show signs of stability and has been subject to an increasing amount of government and policy attention, particularly in relation to the shortage of housing supply. Whilst the demand side of the NI housing market recovered to more normalised levels, housing supply remains persistently below the level of structural demand estimated for the NI economy. In 2017, the Department for Communities established the Housing Market Symposium to address housing-related issues. In its final report, published in January 2018, it identified an undersupply of homes that equated to a requirement for an additional 2,000 dwellings annually, over and above average Housing Growth Indicator estimates. It also noted that the local SME construction sector was unable to match demand. Statistics produced by the Northern Ireland Statistical Research Agency (NISRA) also highlight the persistently low level of new housing construction showing that private sector housing productivity has dropped from circa 9,200 per annum to circa 8,300 per annum over the period of 2011 to 2020 (NISRA, 2020). In a similar vein, the Housing Supply Forum published a report in 2016 highlighting the many challenges facing the sector, including a lack of suitable land, a sluggish planning system, inadequate infrastructure, access to finance and limited capacity within the SME construction sector. This was also noted in research undertaken by Haran et al. (2019) which further identified the construction sector, and housing supply alongside housing finance to be impacting upon market equilibrium, which they indicated is compounded by limited land availability and ongoing challenges emanating from within the planning system and the protracted reform. These dynamics continue to be a major factor keeping pricing levels buoyant, however have served to keep housing affordability as a key and pressing societal issue in Northern Ireland. 
The housing market imbalance and price movements have also been operating alongside changing market structures, particularly within tenure patterns. The growth of the PRS has been mostly facilitated by supply-side policy reforms such as the introduction of assured short-hold tenancy agreements and the wholesale removal of rent control - increasing buy-to-let investment opportunities (McCord et al., 2014). As outlined by Frey and Grey (2012), between 2001 and 2006 the PRS exhibited a 64 percent growth in the number of dwellings, which was attributed to increased investors entering the market. By 2009 the expansion of the PRS displayed a further increase of 54 percent from 2006 levels representing 17 percent of total housing stock - higher than the rest of the UK (McCord et al., 2014). Further, the NI residential market has also been shaped by its constantly changing demographic structure, which has seen the population of the region increased from $1.8 \mathrm{~m}$ to $1.9 \mathrm{~m}$ (or an $0.05 \%$ annual growth) (NISRA, $2020)^{2}$. Despite a negative net migration of residents as a result of the U.K.'s departure from the EU, the demand for housing has been relatively strong, due primarily to an increase in natural population change and the projected increase of number of households driven by the tendency of the older population to reside in larger households (NISRA, 2020).

As outlined by Arena et al. (2020) many European economies are experiencing house price increases over the past few years due to demand factors such as household incomes and wealth, rising population, migration, lower interest rates, availability of credit and through supply, policy, and structural factors such as debt financing and rental market regulations. Hartmann (2015) in a review of Real estate markets and macroeconomic and macroprudential policy in Europe, highlighted that European property price developments showed differing price trajectories, which are attributed to the varied institutional and macroeconomic factors which displayed differential impacts and fluctuations demonstrating strong regional components.

Consequently, given the theoretical and apparent bi-directional, causal relationships and imbalances between the housing market, broader economy, financial environment and market fundamentals, it is important to understand the relationship between macro- and micro-economic characteristics in relation to the P-t-R ratio to enhance the understanding of housing market dynamics. As Borgersen (2020) emphasises, although the P-t-R ratio is widely used as a measure of over- and undervaluation in the housing market, surprisingly little is known about the theoretical relationship between the P-t-R ratio and market fundamentals such as interest rates and down payment requirements. This paper therefore examines the temporal interactions of the P-t-R ratio and economic and financial determinants. Specifically, we examine this relationship at the aggregate position and also across housing types within the housing market to establish whether there are subtle differences in how various housing segments react to changes in economic activity and market fundamentals. To do so, we apply cointegration and causality methods to determine whether there is any short- and long-term lead-lag relationships between the different property types with respect to their P-t-R ratios and macroeconomic variables. These

2 See NISRA (2020). 
insights serve to inform housing and economic policy and macroprudential policy design and the effect of regulatory interventions and further enhance the understanding of the P-t-R ratio on housing market structure and dynamics.

The reminder of the paper is presented as follows: Section 2 discusses the literature with particular emphasis placed on the macroeconomic attributes that affect the P-t-R ratio in various international housing markets. Section 3 describes the research methodology of the study, covering the technical aspects of the various statistical tests employed. It also depicts the sample data and provides some useful descriptive statistics on the Northern Ireland residential market. Section 4 reports the results of the empirical tests, including those of the Cointegration and Granger Causality with Section 5 discussing the key research findings arising from the empirical tests. The last section concludes the study, which summarises the findings, discusses potential implications, provides directions for future research in the topic area.

\section{Literature Review}

Housing market equilibrium can be assessed from a number of perspectives and angles. From a price determination perspective, the causal interaction between real estate pricing and rents as well as the relationships between the P-t-R and other economic fundamentals are enshrined in the DiPasquale and Wheaton's Four-quadrant Model (1992). The Model portrays that price is determined by, or lags, rents since the former could be viewed as the summation of all future discounted rental incomes. The total amount of housing stock and the demand for real estate jointly affect the level of rent, which subsequently result in a change in the price level through the process of capitalisation. The rate of capitalisation is commonly termed as the current yield of the housing investment, which is the opportunity cost or profitability rate that property traders require to acquire property assets. Based on the Model, four main economic factors jointly determine the fashion in which the current yield is formed in the long-run, namely the expected growth rate in rental income, the long-term interest rate, the overall risk associated with the generation of rental income, and relevant taxation policy. The theorisation of the Model is indeed inspired by other seminal works such as Fisher (1930) and Rae (1934) who examined interest rates as a principal factor governing the pricing of various commodities, as well as the variation of utility of a given commodity with respect to the change in opportunity cost.

A number of studies in the literature have attempted to explain the joint dynamics of property prices and rents utilising different methodological approaches and datasets. Sommer et al. (2010), for instance, examined the association between property prices and rents for the USA by employing a dynamic equilibrium stochastic life-cycle model of housing tenure choice. Their findings suggested that more than $50 \%$ of the increase in the US resident property P-t-R ratio between the period of 1995 and 2005 was attributable to lower interest rates, less restrictive lending requirements and higher income levels. These three factors also resulted in more rapidly increasing property prices, sluggish rents, increasing 
homeownership and higher household indebtedness during the investigation period. In a similar study, Kishor and Morley (2015) examined various factors that affect the P-t-R ratios of the eighteen metropolitan statistical areas (MSAs) in the U.S by conducting a present value analysis based on Campbell and Shiller's (1988) modelling framework. In their study, they observed that the Present Value Residual (PVR) components were approximately 30\% larger than the size implied by the present value model for large MSAs such as New York, Los Angeles and Miami during a property boom period. The empirical results further revealed that MSAs whose deviations from the PVR are large are more responsive to change in mortgage rates, which implies a high degree of heterogeneity with respect to monetary policy. In addition, the authors uncovered that housing supply elasticity tended to be correlated to PVR, inferring that MSAs with larger PVR are statistically likely to exhibit inelastic housing supply.

In a similar paper, Campbell et al. (2009) in a variance decomposition of the P-t-R ratio applied a dynamic Gordon growth model across 23 US metropolitan areas over the period 1975 to 2007. Dissecting the P-t-R ratio to be compartmentalised into the expected present discounted values of rent growth, real interest rates, and a housing premium over real rates, the authors established that housing premia account for a significant fraction of rent-price ratio volatility at both the national and local level. In a Chinese context, $\mathrm{Wu}$ and Jiang (2012) evaluate the price-to-rent and price-to-income ratios across a number of urban areas. Their findings indicated that high house price increases result in distortions between the relationship and forcing rental price inflation posing structural challenges in terms of supporting the mainstream market. Concomitantly, the authors show that the price-to-income ratio varies in different cities identifying that a paradox exists amongst groups with different income levels. In the context of the Irish property market, Kim and Lim (2014) explored the variations in the P-t-R ratio between 1976 and 2012 in the framework of the Campbell-Shiller present value equation, which was designed to decompose the P-t-R into the present discounted values of expected future real estate market fundamentals. The results, based on the maximum likelihood estimation approach, suggested that the variations in the P-t-R ratio can, in a large part, be explained by the expected housing premium, whereas real interest rates and expected rental growth are less significant factors affecting the ratio. Borgersen (2020) provides a conceptually different approach by distilling out the relationship between the loan-to-value (LTV) ratio and the price-rent (PR) ratio through incorporating the funding structure of housing investment. By formalising the relationship between leverage and housing return, as suggested by Muellbauer and Murphy (1997), the authors found the effect of a higher LTV on the user cost of housing as the net effect of a higher borrowing cost and the associated leverage gain, showing that the latter is dependent upon the relationship between house price growth and mortgage rates. 
Numerous other empirical studies within housing literature have shed light on the P-t-Rs on market structure. Prominent works include Bracke (2015) who investigated the micro-spatial house price dynamics within central London, highlighting that the level of affluence of a given neighbourhood is closely associated with P-t-R. Indeed, the study echoed the findings of previous research by Smith and Smith (2006) who demonstrated that high-end houses in ten sample US urban residential markets exhibited larger P-t-R ratios than those of low-end counterparts. Clark and Lomax (2019) utilised matched transaction and rental data of dwellings in England to examine the impact of location and property type upon the variation of P-t-R ratio in different residential submarkets, establishing a relationship that the physical desirability of a property or neighbourhood is intimately linked to the ratio with better housing generally displaying a higher P-t-R. In addition, the study revealed that detached and semi-detached houses, relative to apartments and terraced houses, exhibited higher P-t-R ratios, whilst distance to city centre and time on the market (i.e. the length of time between listing and sale) are factors that depress P-t-R.

More recently, Lo et al. (2021) empirically demonstrated that P-t-R ratio is highly dependent on the characteristics of the property submarket concerned. Specifically, by examining the Belfast (U. K.) residential market at a submarket level, the study revealed that the P-t-R ratios of the property submarkets (including detached, semi-detached and terraced markets) are highly cointegrated in the longrun, with the detached sector Granger-causing the P-t-R movements of other sectors. On the other hand, the findings showed the apartment sub-market sector displayed somewhat unique P-t-R features revealing no persistence or Granger causal relationships with the detached and semi-detached sectors but with the terraced and townhouse sectors. Further, the study of McCord et al. (2019) empirically tested the co-movement in-house prices across different property types within Northern Ireland to determine whether price transmissions are propagated contemporaneously into both short-term and long-term price adjustments. Their study established stylised facts of lead-lag relationships across property types finding that the apartment sector systematically and consistently lagged behind all other residential property segments pointing towards obvious market filtration transmission pricing signals in operation in a Granger-causal fashion with property price signals transmitted from the more liquid owner-occupier-led Detached and Semi-detached segments to the Apartment segment, but not vice versa.

From a market perspective, whilst research has examined the P-t-R ratio from a life-cycle model of housing tenure choice or present value perspective, there remains relatively limited insights examining the temporal variations of the P-t-R ratio relative to market determinants and fundamental macroeconomic and financial factors. As outlined in Table 1, a number of studies have sought to analyse the role of mortgage/interest rates (Otto, 2008; Tsai and Peng, 2011; Kim and Lim, 2014, and Lee and Park, 2018), money supply (Tsai and Peng, 2011), housing supply (Kishor and Morley, 2015), housing investment (Guo and Huang, 2010; Zhai et al., 2018), inflation (Tsai and Peng, 2011), exchange rates 
(Bahmani-Oskooee and $\mathrm{Wu}, 2008$ ) and stock market performance (Okunev et al, 2000) vis-a-vis house prices and the P-t-R ratio. Most of these studies have however examined the price to rent dynamics in the context of macroeconomic fundamentals of just one or two particular aspects of the market. Moreover, there remains little empirical work, certainly in the UK perspective, investigating the causal dynamics and relationships of P-t-R ratios by property type which theoretically may be driven by changes in different market and economic determinants and house price and rent movements.

McCord et al. (2019) put forward an explanation that, relative to the detached sector, the terraced and townhouse sectors are close substitutes of the apartment sector, hence the latter three sectors should share similar pricing dynamics, behaviour and causal interactions in the long run. Begley et al. (2019), also decomposing price changes, revealed that the P-t-R moved comparably across all property types. Therefore, we build upon these studies upon which the selection of the macroeconomic attributes of our empirical investigation was based, and test these propositions by investigating the structural dynamics at play within the NI housing market which have impacted on the potential convergence (divergence) between house prices and rental prices and market equilibria, whilst accounting for wider economic and financial factors.

\section{[INSERT TABLE 1]}

\section{Data and Methodology}

In this study, we employ Johansen Cointegration and Granger causality techniques to test for, if any, the existence of cointegration and lead-lag relationships between the price to rent ratios of different property submarkets and a spectrum of macroeconomic and financial variables that we surmise may have a long-term association with the real estate market. The investigation period is 2014Q1 to 2018Q4, which was purposely chosen to minimise the effects arising from exogenous influences given the relatively stable market environment compared to historical trends, thereby enhancing the overall robustness of the study. In particular, the extreme macroeconomic volatility and uncertainty in the immediate aftermath of the GFC were deemed to have a relatively insignificant impact on property price movements during the sample period, ensuring that our analysis only captured a temporal process of steady market recovery and growth in which the dynamics between the variables examined could be observed in a more distinct and objective fashion. Further, the Rental Index for NI only commenced in 2014, prohibiting a more elongated time series from being examined. Accordingly, we create a quarterly time series for the P-t-R ratio of the Northern Ireland residential market $\left(P R_{A}\right)$ using quarterly prices and rents which are derived from an established property index (UU HPI) and rental index (UU RPI) 
which are calculated based on large and representative samples size of open market transactions ${ }^{3}$ in Northern Ireland.

Further, to empirically examine the price/rent dynamics of the aggregate residential property market, we examine the P-t-R ratios of the four main property sub-markets of the region, including (i) Detached $\left(P R_{d}\right)$, (ii) Semi-detached $\left(P R_{S}\right)$, (iii) Terraced $\left(P R_{t}\right)$, (iv) Apartment $\left(P R_{a}\right)$. We conjecture that each of these sub-market segments might exhibit varying degrees of association/disassociation with the array of macroeconomic indicators investigated by virtue of its own underlying demand and supply fundamentals.

Following the conjectures of Tsai and Peng (2011), we contend that the potential effect of inflation on the P-t-R ratio could be empirically ambiguous depending critically on the actual fundamentals of the market: If the general price level indeed moves in tandem with the property market, then a surging inflation rate should, on average, lead to higher property prices, and hence a higher average P-t-R ratio, given that rents tend to lag behind residential sales prices due to the contractual rigidity in making rental adjustments. On the other hand, inflation could erode the overall purchasing power of the potential homebuyers, reducing the demand for housing. In this scenario, the P-t-R ratio should decrease. In terms of interest rates, the real interest rate is a key determinant of the user cost of housing. Theoretically speaking, and as outlined by Otto (2008), a higher interest rate should depress housing prices, which in turn should result in a lower P-t-R ratios assuming the rental movements remain constant.

Existing research has shown housing and stock markets to be cointegrated (Ludwig and Sløk, 2004; Kakes and Van Den End, 2004; Apergis et al., 2014; Kishor and Morely, 2015). To test any potential impact of financial markets, the FTSE is employed to proxy the general performance of the UK financial market, which is the most widely used stock market indicator for the country. In addition, we also consider the quarterly growth rates of the indices (FTSE_GROWTH). In line with Bahmani-Oskooee and $\mathrm{Wu}$ (2018), we contend that the exchange rates between the British pound sterling and other major currencies could have a significant impact on the U.K. property market and any potential pricing arbitrage. Generally speaking, a lower value of one currency relative to others should attract more international investors to invest in the local real estate market, other things being equal, which should subsequently drive property prices. Hence, the P-t-R ratio should increase when the currency depreciates against other currencies. In other words, the exchange rate can be viewed as an indicator measuring the relative attractiveness of domestic products, including real estate. In this study, we

\footnotetext{
${ }^{3}$ The UU HPI was established in 1984 and records circa $40 \%$ of residential property transactions across the region of NI. The HPI measures the current price and quantities in relation to the base period. The index is based on quarterly returns obtained from 103 contributory estate agency practices from across Northern Ireland and supplemented with recorded and verified sale transactions from Propertynews.com. The sales information is also cross-correlated with the domestic capital valuation Rating List for inspection and verification of attribute information.
} 
employ two exchange rates, namely EUR/GBP and USD/GBP, to proxy the relative attractiveness of the U.K. housing market from the perspective of foreign investors.

Previous research studies (e.g. Tsai and Peng, 2011) revealed that an expansionary monetary policy could be a cause of the formation of a housing bubble, which potentially signals a divergence of price and rent over time. Thus, monetary supply plays a critical role in the determination of the overall price level and inflation of an economy. The quantity theory of money states that the aggregate price level of an economy is directly proportional to the amount of money supply, holding the velocity of money and real output constant. Therefore, we test if the supply of money impacts upon the P-t-R ratio of the NI housing market and whether this is different for each respective property type. We utilise the growth rates of two of the most commonly-used money supply indicators (M2 and M3) as our explanatory variables in the empirical testing.

Numerous studies have established an empirical relationship between the general economic productivity and the real estate market, including Green (1997), Coulson and Kim (2000), Chan and Woo (2013). In our analysis, we employ the quarterly Northern Ireland Composite Economic Index (NICEI) ${ }^{4}$, compiled by the Northern Ireland Statistics and Research Agency (NISRA), to represent the overall output of the Northern Irish economy. To the extent that the real estate market is in sync, or causally interlinked with the general economy, we should expect that the P-t-R ratio would be cointegrated and/or display a lead-lad relationship with NICEI. Aside from examining the general economic productivity of Northern Ireland, we further explore the temporal relationship between the productivity of the construction sector and the real estate sector. We utilise the NICEI (Construction) sub-index to determine the total output of the construction. It is well-established in the DiPasquale and Wheaton Model (1992) that the output of the construction sector has a direct impact upon the price of real estate in general, with the degree of impact governed by the elasticity of the housing supply.

In our analysis, two indicators are utilised to investigate the effect of new housing stock on the P-t-R ratio, namely the total amount of new housing investment $\left(\mathrm{NH}_{t}\right)$ and the amount of new private housing investment $\left(\mathrm{NH}_{p}\right)$. Intuitively, we believe that the property prices and rents should be negatively affected by the amount of new housing supply coming to the market, holding other things constant. However, we suggest that the causal dimension of the relationship could be less clear empirically for the various housing submarkets examined since they exhibit different characteristics in relation to the underpinning demand-supply fundamentals, as well as the composition of the homebuyers. Table 2 provides a summary and description of the variables included within the study.

\footnotetext{
${ }^{4}$ The quarterly updated index is based on the economic performance of various sectors of the economy including construction, public services, manufacturing and private services.
} 
where $Y_{t}$ is the level of the time series; $\alpha$ is an intercept term and $T$ is a time trend; $k$ denotes the total number of time periods for achieving white noise, which is governed by the Schwarz Information Criterion (SIC); and $\varepsilon_{t}$ is an error term with a zero mean and constant variances.

\section{Cointegration Tests}

We utilise the Johansen Cointegration tests developed by Johansen $(1991,1995)$ in a bivariate setting to detect whether long term cointegration relationships between a pair of time series exist. In line with Leung et al. (2006) we apply a bivariate ECM regression framework instead of a multi-variate VECM for our analysis. Given the reduced sample period under investigation, as well as the large number of independent variables included in our study, the degree of freedom and the precision of the models would drop significantly if a multi-variate approach was adopted ${ }^{5}$. Indeed, a large volume of research has utilised the bi-variate cointegration and/or Granger causality modelling approach to examine real estate problems or macro-economic issues in general which are constrained by sample size. Leung et al. (2006) studied the relationships between housing price dispersion and a large spectrum of macroeconomic attributes by developing a set of parsimonious bi-variate ECM equations; following a broadly similar bivariate ECM-based method, Newell and Chau (1996) and Zou and Chau (2020) explored the linkages between direct and indirect real estate, and the association between oil price and oil consumption respectively.

As a general rule, the components of a vector $V_{t} \sim \mathrm{CI}(\mathrm{i}, \mathrm{j})$ are said to be cointegrated of order $\mathrm{i}, \mathrm{j}$ if and only if $V_{t}$ is I(i) and we can find a non-zero vector $\alpha$ such that $\alpha^{\prime} V_{t} \sim \mathrm{I}(\mathrm{i}-\mathrm{j})$ where $\mathrm{i} \geq \mathrm{j}>0$. $\alpha$ is commonly known as cointegrating vector. Cointegration is said to exist if there is a long-term equilibrium

\footnotetext{
${ }^{5}$ In response to one of the anonymous reviewer's comments, the bivariate ECM modelling method, statistically speaking, does not in any way compromise the empirical robustness and validity of the research findings.
} 
relationship between these time series. To statistically observe whether there exists a cointegration relationship between two $I(1)$ variables, say, $X_{t}$ and $Y_{t}$, we run a regression of $Y_{t}$ on $X_{t}$ in line with Engle and Granger (1987). Unit root tests are then conducted to check the presence of unit root(s) in the regression residual of the equation. To achieve this, the following equation is formulated:

$$
Y_{t}=\alpha+\beta X_{t}+u_{t}
$$

Equation 2 is commonly known as cointegrating regression. $X_{t}$ and $Y_{t}$ are cointegrated if $u_{t}$ is a stationary time series, which can be vindicated by undertaking the ADF test on $u_{t}{ }^{6}$. Nevertheless, Dickey et al. (1991) point out that the method proposed by Engle and Granger (1987) could indeed be sensitive to the choice of the regressand(s), potentially giving rise to inconsistent estimates. Alternatively, Johansen (1991 and 1995) suggests testing the following equation to conduct the cointegration test:

$\Delta Y_{t}=\eta Y_{t-1}+\sum_{i=1}^{k} \mathrm{r}_{i} \Delta Y_{t-i}+B X_{t}+\varepsilon_{t}$

where $\eta=\sum_{i=1}^{k} A_{i}-I$ and $\mathrm{r}_{i}=-\sum_{j=1+1}^{k} A_{i} . Y_{t}$ denotes a k-vector of $\mathrm{I}(1)$ that is non-stationary. $X_{t}$ is a $d$ vector of deterministic variables and $\varepsilon_{t}$ is a vector of white noises with zero mean and constant variance. $\eta$ represents the rank of the coefficient matrix, which indicates the number of cointegrating vectors. To illustrate an example in our analysis, we test the following cointegration equation:

$$
\Delta \mathrm{PR}_{t}=\eta P R_{t-1}+\sum_{i=1}^{k} \mathrm{r}_{i} \Delta P R_{t-i}+F T S E_{t}+\varepsilon_{t}
$$

where the dependent variable, PR, is the price-to-rent ratio and FTSE is the FTSE index. Equation 4 essentially tests whether a long-term cointegrating relationship exists between PR and FTSE. Procedurally, it can be flexibly modified by substituting $\mathrm{Y}$ and $\mathrm{X}$ with other variables to examine the relationships between any two time series of interest in our study.

Johansen (1991) further indicates that the cointegration test should be conducted by estimating $\eta$ in an unrestricted form to determine whether or not the restrictions suggested by the reduced rank of $\eta$ can be falsified. Trace test statistic can subsequently be obtained by conducting the likelihood ratio (LR)

\footnotetext{
${ }^{6}$ Given that the cointegration tests are conducted within a bivariate framework, only one cointegrating relationship is assumed. In other words, the maximum cointegration rank is one minus the number of variables. (See, for instance, Patterson (2000) and Juselius et al. (2013)).
} 
test for the hypothesis that there are at most $r$ cointegrating vectors ${ }^{7}$. As suggested by Engle and Granger (1987), the variables of the analysis should be integrated of order one.

\section{Granger Causality Test in Error Correction Models (ECMs)}

As pointed out by Engle and Granger (1987) and Granger (1988), if two time series are cointegrated, the modeller could mis-specify their long term relationship if the traditional Granger method is utilised to test for causality. Hence, an ECM approach to Granger causality testing should be adopted and its equation can be expressed as follows:

$$
\Delta Y_{t}=\lambda++\sum_{i=1}^{p} \alpha_{i} \Delta Y_{t-i}+\sum_{j=1}^{q} \beta_{j} \Delta X_{t-j}+\phi z_{t-1}+\varepsilon_{t}
$$

where $\lambda$ is the constant term of the equation. $\mathrm{p}$ and $\mathrm{q}$ are the number of time lags that are large enough to obtain an error term $\varepsilon_{t}$ that is white noise. $z_{t-1}$ is commonly known as the error correction (EC) term and $\phi$ is the coefficient to be estimated.

An ECM Granger causality test is of great statistical appeal in the sense that it is informationally implicative. It detects both short- and long-run equilibriums and/or dynamics of a given pair of time series that are cointegrated. In Equation (5), $\beta_{j}{ }^{\prime} s$, which indicates the impact of lagged independent variables $\Delta X_{t-j}$, represents the short-term impact of $Y$ on change in $X$. In other words, $\beta_{j}$ measures the short term elasticity of $\mathrm{Y}$ with respect to $\mathrm{X}$. On the other hand, $z_{t-1}$ signals the long run dynamic between the two variables. Mathematically, $z_{t-1}$ takes the form of:

$z_{t-1}=Y_{t-1}-w_{0}-w_{1} X_{t-1}+w_{2} t$

$w_{1}$ is the coefficient of $X_{t-1}$, which indicates the magnitude of long run elasticity of $\mathrm{Y}$ with respect to $\mathrm{X}$ (Thomas, 1997). $\mathrm{t}$ is a time trend over the entire investigation period and $w_{2}$ is the corresponding coefficient. In addition, $\phi$, reflects the velocity with which the variables adjust their short-term disequilibria towards a long term equilibrium, or the degree of adjustment the short run disequilibria attained relative to their long run equilibrium during the subsequent time period. Hence, $\phi$ is commonly called the coefficient of adjustment.

Mathematically, the sign of the EC term should be positive if changes in the dependent variable are greater than its average value. Put differently, $\Delta Y_{t}$ tends to move downwards to converge to the path of

\footnotetext{
${ }^{7}$ Following the recommendations given by one anonymous reviewer, we conducted further tests to obtain the eigenvalues of the cointegration equations. The results are reported in Table 6.
} 


\section{Results and Descriptive Statistics}

The average price within the Northern Ireland housing market equates to circa $£ 150,000$ in 2018 Q4, whereas the average rent during the same period is approximately $£ 7,700$ (Table 3 ). As in other regions of the U.K., the Detached sector in Northern Ireland is the smallest in terms of stock size $(\mathrm{n}=1,489$ or $3.46 \%$ ) yet the most expensive with an average sale price of circa $£ 207,000$ and an average annual rent of circa $£ 10,500$. The Semi-detached sector, being the second most unaffordable in terms of pricing, commands an average price of circa $£ 165,000$ and an average annual rent of $£ 8,200$. The two sectors with the largest sample size and housing stock, namely Terraced ( $\mathrm{n}=18,266$ or 42.5\%) and Apartment $(n=17,940$ or $41.7 \%$ ) are relatively more affordable with average prices of $£ 98,469$ and $£ 130,000$ respectively. Not surprisingly, they also report the lowest average annual rents of $£ 6,800$ and $£ 7,900$. Table 3 provides some descriptive statistics of the four property types as in 2018 Q4.

\section{[INSERT TABLE 3]}

As evidenced in Figure 1, the P-t-R ratios at the aggregate level and for the distinct property types show some quite disparate trends over the investigation period. In line with previous UK-based research findings (e.g. Lo et al., 2021) the Detached submarket has been consistently demonstrating the highest price-to-rent ratios relative to those of the other submarkets, hovering in the region of $20-36$ for most of the quarters examined. Pertinently, this is due primarily to the fact that the Detached sector is buyerdominated. Nonetheless, the detached sector displays more pronounced volatility over the time series 
and shows an increase in the P-t-R ratio from 24.75 in Q1 2014 to 36.88 in Q4 2015 in line with wider macroeconomic cyclicity. On the contrary, the two renters-driven submarkets, namely Terrace and Apartments, display the lowest ratios throughout the sample period. It is also discernible that the terrace sector displays a relatively consistent trend around a P-t-R of 14 over the period and displays the lowest P-t-R ratio overall. Semi-detached exhibits a more consistent trend similar to that of the aggregate market between Q1 2014 to Q1 2017, with price-to-rent ratios fluctuating between 20 and 24. Similarly, the Semi-detached segment of the housing market exhibits a consistent trend, where it displays more variability until Q1 2018 where it also stays constant to Q4 2018.

\section{[INSERT FIGURE 1]}

Correlations between the various segments are undertaken to examine the interrelationships amongst the price-to-rent ratios of the submarkets. Most noteworthy is the negative correlations between Apartment and all other submarkets. For instance, the correlation coefficient between Apartments and Detached is -0.48 , inferring that the two sectors tend to move in opposite directions in terms of their price-to-rent dynamics over time. On the other hand, Detached and Semi-detached reveal a moderately positive coefficient $(\mathrm{r}=0.36$ ), seemingly suggesting that there is a weak positive temporal association between their respective price-to-rent ratios.

Further exploration of the correlations between the P-t-R ratios and the macroeconomic variables uncovers some preliminary empirical findings (See Table 4). First and foremost, the Northern Ireland housing market at the aggregate level responds to the macroeconomic factors differentially, with the USD/GBP being the most positively correlated to the P-t-R ratio of the market ( $\mathrm{r}=0.37$ ), followed by EUR/GBP $(r=0.26)$. This seems to suggest that real estate in Northern Ireland is quite sensitive to the foreign exchange market, perhaps partially due to the massive depreciation of the British pound sterling after the Brexit vote in 2016. Secondly, the housing market is to a large extent quite compartmentalised by property type as evidenced by the varying degrees of correlation to the macroeconomic attributes, indicating that there is divergence in how each housing submarket responds to macroeconomic forces. For example, the Detached sector is highly positively correlated to the two exchange rate variables but negatively correlated to the stock market variable and money supply variables. The Terrace sector is more responsive, albeit negatively, to the movement of inflation rate as indicated by the negative correlation coefficient ( $\mathrm{r}=-0.40)$. The Apartment segment of the market does not display any sizeable associations with most macroeconomic variables except the NICEI $(r=0.30)$. Accordingly, we shed further light on the interactions between the P-t-R dynamics across property types and the macroeconomic climate using Cointegration and Granger Causality tests. 
[INSERT TABLE 4]

\section{Results of ADF Tests and Cointegration Tests}

As pointed out by Hamilton (1994), if a time series displays a time trend, whether it is stochastic or deterministic, consideration should be given around incorporating an intercept term and a time trend. Given that the time series under investigation appears to contain a time trend and contain non-zero means based on our initial graphical analysis, we therefore include both a constant term as well as a time trend within the analysis. The key results of the ADF tests are reported in Table 5. Most of the time series are stationary at level or at first difference at the 5\% significant level except for CPI and $\mathrm{M} 3$, which contain no unit root only when they are treated as $I(2)$. Consequently, in the following sections we apply differencing according to the stationarity of the time series, which is in line with Granger and Newbold (1974).

\section{[INSERT TABLE 5]}

Determined by the trace statistics and eigenvalues, the results of the Johansen cointegration tests on each pair of P-t-R variables and macroeconomic indicators are reported in Figure $6^{8}$ with a number of interesting findings observed. Inflation is only cointegrated with the P-t-R ratio within the Semidetached segment of the market. Second, whilst all property types are cointegrated with the FTSE, the aggregate level P-t-R ratio is not. Similarly, the results on the exchange rate variables reveal some contrasting empirical observations. For example, EUR/GBP display a long-term cointegration relationship with all housing segments except for the aggregate level and Terrace sector; with USD/GBP cointegrated with all housing types except for Detached.

Money supply (M3) seems to be a more useful indicator in explaining the pricing dynamics of the NI housing market than $M 2$. The former is cointegrated with all housing types, whereas the latter is only moving in tandem with the Detached market. Equally, all P-t-R ratios exhibit a long-term cointegration relationship with mortgage interest rates (MIR), the NI Composite Economic Index (NICEI) and the construction related Economic Index $\mathrm{NICEI}_{c}$. Lastly, the analysis shows the P-t-R ratio is generally progressing concurrently with the amount of private housing investment growth but not the counterpart of total housing investment, given that the trace statistic is statistically significant for $\mathrm{NH}_{\mathrm{p}}$ but not for $\mathrm{NH}_{\mathrm{a}}$. In addition, the price-to-rent movement of the Detached sector appears to be insensitive to both housing investment variables in terms of cointegration as depicted by the trace test statistics (Table 6).

\footnotetext{
${ }^{8}$ We employ the $95 \%$ confidence interval using the trace statistics to determine whether a cointegration relationship exists.
} 


\section{[INSERT TABLE 6]}

The results of the cointegration analysis provides the methodological basis for the subsequent Granger causality tests: if a given pair of variables are cointegrated in the long-run, then an ECM causality approach is applied, otherwise the lead-lag relationship is examined within a non-ECM framework. Table 7 depicts the results of the Granger Causality tests with the Chi-square statistics and $p$-value reported (in parenthesis) for each pair of time series investigated - based on the $95 \%$ confidence level. The findings reveal that the macroeconomic variables are causally correlated with the P-t-R ratios of the different housing sectors in a relatively disparate fashion. For instance, Inflation Granger-causes only the Semi-detached submarket (in the long-run) but not the other market segments. The stock market variable, FTSE, seems to lag behind the P-t-R ratio across the various housing types, but not at the aggregate level. As regards to the pricing dynamics relative to the exchange rates, EUR/GDP seems to be, in a Granger sense, a driver for the Detached and Apartment submarkets in the long-term. However, it is interesting to note that the P-t-R ratio of the Semi-detached sector indeed leads the exchange rate variable. On the other hand, the USD appears to Granger-cause the P-t-R of the aggregate market as well as those of the Semi-detached and Apartment sectors in the long-run, with short-term lead-lag relationships further empirically confirmed for the latter two sectors. Indeed, the Apartment sector shows a bi-directional Granger causal interaction with USD/GBP over the long-run.

Similar to the results for cointegration, M3 seems to display a stronger association with the housing market in terms of Granger causation than M2. For instance, the findings indicate that M3 dictates the P-t-R movements of both Semi-detached and Terrace types, whilst the opposite causation is observed at the overall (aggregate) market level in the long-term. It is further noteworthy that mortgage interest rates, IRs, Granger-causes the P-t-R interactions of Semi-detached, Terrace and Apartments in both the short- and long-term, yet it is Granger-caused by the Detached sector. The causality tests also confirm that the productivity of the construction sector, as proxied by NICEI (construction), is a lagging indicator of the P-t-R ratio across all housing submarkets. Last but not least, the results show that the volume of new private housing investment displays a strong and consistent Granger-causal relationship at the aggregate level and with all house types except for Detached with respect to their P-t-R ratios, with the causal link running from the former to the latter. On the other hand, total new private investment is only interlinked with the Terrace submarket, with the latter Granger-causing the former in both the short- and long-term.

[INSERT TABLE 7]

\section{Discussion of results}


The empirical analysis has provided some noteworthy and important insights into the interaction between housing P-t-R dynamics and macroeconomic fundamentals of various segments of the economy, including the financial sector, construction industry and the foreign exchange market. First and foremost, the long-term temporal association between the inflation rate and the P-t-R ratio does not seem to be significant across the Northern Ireland housing market, albeit it is notable that some evidence of the Semi-detached sector being Granger-caused by CPI is observed. Further exploration of the data reveals that the quarterly year-on-year inflation rate declines from $0.8 \%$ to $0.2 \%$ during the sample period whilst the aggregate P-t-R ratio hovers narrowly between 20 to 24 during the same period. It can therefore be inferred that the housing market exhibits, in terms of affordability, a different growth trajectory than that of the general market of goods and services.

Existing research has empirically demonstrated that the stock market and housing market are tied (Green, 2002; Ludwig and Sløk, 2004; Kakes and Van Den End, 2004; Apergis et al., 2014; Kishor and Morely, 2015). Our findings reveal the FTSE index to be highly cointegrated with the P-t-R ratios of the different housing types, but interestingly, not with that of the aggregate housing market. Furthermore, it is evident that only certain submarkets such as the Semi-detached and Terraced Grangercause the movement of the stock market, which further signals the housing market in Northern Ireland seems to be highly compartmentalised by property type in terms of pricing behaviour. The findings also show that the foreign exchange market is found to play a crucial role in dictating the P-t-R dynamics of the property market. Indeed, the results established evidence, for example, that EUR/GBP Grangercauses the P-t-R movements for Detached and Apartments, and USD/GBP Granger-causes Terrace houses and Apartments in the long-run. Indeed, the ECM results further indicate a significant bidirectional causal relationship between USD/GBP and Apartments in the long run. This is perhaps not surprising given that the Northern Ireland housing market is, to a large degree, driven by the inflows and outflows of international investment capital, particularly FDI from Republic of Ireland. As a result of the UK's departure from the European Union in 2016, the depreciation of the British pound sterling against other major international currencies such as the USD has indeed made the Northern Ireland residential market a favourable long-term investment option for many global institutional investors and specifically private equity players looking to gain exposure, en masse, to residential direct real estate in the U.K.

The cointegration analysis further suggested that the flows of capital (monetary supply) are cointegrated with all P-t-R time series, confirming a consistent linkage between money supply and the housing market at both aggregate and submarket levels. The findings of the Granger Causality tests further demonstrated that, albeit less statistically conclusive and significant, the growth rate of money supply indeed leads the Semi-detached and Terrace sectors in the long-run, which collectively account for over half of the total stock of the housing market. This is consistent with our assumption that the effect stemming from the government monetary policy such as Quantitative Easing has been long lasting with 
the market persistently buoyed by the inflows of new capital created in a low-interest environment. The findings are also in accordance with Cronin and McQuinn (2016) who demonstrated the role of credit availability and flows to drive P-t-R ratios within the Irish market. However, it is notable that when a more narrowly defined money supply (M2) variable is used, the results of the cointegration and causality tests become considerably less significant across most of the house types examined. We attribute such difference in the results to the fact that the more expansive definition of monetary supply (M3) covers a broader spectrum of money, including institutional funds which have been one of the key drivers of the Northern Ireland property industry over the last 10 years and the sample period.

Literature demonstrating a relationship between mortgage interest sensitivity and house prices is long and extensive (Brasington and Sarama, 2008; Damen et al.,2016; Downing et al., 2005; Hubbard and Mayer, 2009; McQuinn and O'Reilly, 2008). Kishor and Morely (2015) established that house price ratios which have higher present value residual components are more sensitive to mortgage rate changes. It is also discernible from our results that there is a long-term cointegrating relationship between mortgage interest rates and all P-t-R ratios, implying that the pricing behaviour of every housing segment is strongly correlated to the lending market over a longer-time horizon. Further examination of the lead-lag relationships between the housing sectors using Granger causality techniques revealed notable insights. The P-t-R ratio of the Detached sector indicated a bi-directional Granger-causal relationship with mortgage interest rates, which in turn Granger-causes the P-t-R ratios of the other three submarkets in both the short- and long-term. This is largely in line with other previous research findings of Lo et al. (2021) which found that the Detached property sector causally leads other property types of lower strata in the price discovery process of the market. Essentially, the Detached segment, characterised by its composition of investors and homebuyers of higher purchasing power, and a longer investment planning horizons, tends to "set the tone" for other housing segments through the spill-over of pricing signals over time.

Further, our results in line with Green (1997) reveal that all P-t-R times series, are long-term cointegrated with both NICEI and NICEI (construction), seemingly suggesting that the property market, by-and-large, is moving synchronously with other sectors of the economy, in particular the construction industry. In addition, based on the results of the Granger causality tests, the P-t-R dynamics tend to Granger-cause the overall productivity of the construction market with four out of the five submarkets (including the aggregate market) exhibiting a Granger causal link running from the former to the latter. This finding, we posit, can be explained by the DiPasquale-Wheaton (DW) Model which indicates that the level of construction of new housing assets is, broadly speaking, dependent upon the prices of real estate and/or the P-t-R ratio.

Last but not least, it is empirically discernible that total new private housing investment growth seems to be a more accurate indicator that explains/predicts future pricing behaviour of the housing market 
than the counterpart of total new housing - a finding concomitant with Kishor and Morely (2015) who found a correlation between shocks to expected rent growth, and the expected housing return. More specifically, our Granger causality tests reveal that the growth in the volume of private new housing Granger-causes the P-t-R ratios of the Semi-detached, Terrace and Apartment sectors in both the shortand long-run. This finding, on first viewing, appears counter-intuitive as the increased supply of new private housing should theoretically depress price, which in turn may result in a more subdued level of prices to rents. However, it can also be argued that the elasticity of private housing supply could in practice have a larger impact on the rental market then on the sales market, especially in the context of the Northern Ireland market where recent years have witnessed a sizeable increase in the supply of apartment buildings and student accommodation. In other words, the reduction in the average rent due, for instance, to a supply shock, could be greater than that of the average sales price, giving rise to a higher P-t-R ratio. This finding was also notable in the research of Cronin and McQuinn (2016) who also linked this to macroprudential policy measures and implications of constraints on LTV ratios on relative prices (purchasing versus renting) in the housing market. They found that reduced LTV ratios raise rents relative to house prices over the longer-term which they identified comprises important implications, including when there is a need to stimulate the rate of housing supply.

\section{Conclusions}

The behaviour of house prices and rental prices are important prognosticators for understanding housing markets, and in particular whether the pricing structure is representative of underpinning demand and supply fundamentals, or whether a market 'bubble' may be forming and wider social policy issues relating to housing market affordability. Accordingly, this paper has investigated the temporal relationships between the P-t-R ratio and wider macroeconomic and financial determinants within the NI housing market and further decomposed these interactions by housing type applying cointegration and causality methods.

Consistent with previous research studies, the findings within this study reveal some very distinct longand short-run relationships between macroeconomic and financial indicators and the P-t-R ratios across the various housing segments. Thus, the findings do point towards market segmentation issues, and more aptly, are in accord with the submarket hypotheses indicating that there are very distinct and subtle differences within and across housing segments of the market, each of which has very unique supply and demand fundamentals. Indeed, the findings emanating out of this study show that the P-t-R ratio can be used as an early measure for establishing the effects of macroprudential policy changes and how these may manifest across housing tiers and quality, and further act as a signal for preventing or at least mitigating future irrational price cyclicity and answering more a fundamental 'buy or rent' question for many considering or attempting to access the housing market. 
The results also exhibit monetary supply, foreign exchange market 'arbitrage' and the stock market to be important drivers of the P-t-R ratio, with price to rent movements seemingly tied, or are in tandem, with the overall economy, particularly with the construction sector. These insights serve to inform housing and economic policy and macroprudential policy design, principally within lending policy, and the effect of regulatory interventions and further enhance the understanding of the P-t-R ratio on housing market structure and dynamics.

In terms of valuation practice, standardised appraisal methods, namely the comparable sales or replacement cost approaches could perhaps use the P-t-R ratio and indeed rental pricing behaviour and signals to further inform the undertaking of appraisals, as these methods are not designed to identify speculative pressures within the housing market and simultaneously provide evidence of current market rents. Equally, the results provide a basis for enhanced understanding of the market in terms of information efficiency and arbitrage strategies for real estate investors, through the comparison of the P-t-Rs of different property types cross sectionally and temporally. At a practical level, the findings could perhaps pave the way to shed some empirical light on not only the price discovery of, but also the interlinkages between different housing segments, providing an evidence-based perspective to compare and monitor the performance of the submarkets which are important for undertaking financial stress tests in provisioning models for lending activity. For example, post GFC saw a considerable increase in 'accidental landlordism' as homeowners were forced to retain housing that they would have preferred to sell.

Clearly, in the NI context, the capacity of rent to cover the costs of ownership varies across the market sectors, a pertinent consideration which could be assessed with more precision than at present. There are obvious implications for the PRS sector in terms of lenders' ability to understand the investment fundamentals at play, regarding yield spreads, drivers of such dynamic performance attributes and possible market signalling. Hence, monitoring of the P-t-R ratio trends, in conjunction with insights such as those presented here, can help inform lending decisions and credit pricing. The increased professionalisation of the PRS sector driven by the Build To Rent (BTR) element and associated institutional investment can also benefit from increased understanding of the market dynamics at play, facilitating aspects such as portfolio optimisation. In the more public sphere, greater understanding from this analysis can facilitate decision making by Government and housing providers such as Housing Associations, as they develop strategies to provide affordable housing, such as co-ownership, rent to buy and affordable rent schemes.

Last but not least, from a public finance point of view, it is in the interest of policy makers to be conscious of how differing pricing structures within a housing market should be understood with respect to the macroeconomic environment in order to facilitate property valuation and assessment of real estate 


\section{References}

Apergis, N., Simo-Kengne, B. and Gupta, R. (2014), "The long-run relationship between consumption, house prices, and stock prices in South Africa: evidence from provincial-level data", Journal of Real Estate Literature, Vol. 22 No. 1, pp. 83-99.

Arena, M. M., Chen, T., Choi, S. M., Geng, N., Gueye, C. A., Lybek, M. T., Papageorgiou, E. and Zhang, Y. S. (2020), Macroprudential policies and house prices in Europe, Departmental Papers/Policy Papers, No. 20/03, International Monetary Fund.

Begley, J., Loewenstein, L. and Willen, P. S. (2019), The price-rent ratio during the boom and bust: measurement and implications", Federal Reserve Bank of Boston and NBER, pp. 1-37.

Bahmani-Oskooee, M. and Wu, T. P. (2018), "Housing prices and real effective exchange rates in 18 OECD countries: A bootstrap multivariate panel Granger causality", Economic Analysis and Policy, Vol. 60, pp. 119- 126.

Benerjee, A., Doladlo, J. J., Galbraith, J. W. and Hendry, D. F. (1993), "Cointegration, error correction, and the econometric analysis of non-stationary data", Oxford University Press, Oxford, U.K., pp. 69-84.

Borgersen, T. A. (2020), "Loan-to-value and the price-rent ratio", Journal of European Real Estate Research, Vol. 13 No. 2, 2020, pp. 149-159.

Bracke, P. (2015), "Housing prices and rents: microevidence from a matched data set in central London", Real Estate Economics, Vol. 43 No. 2, pp. 403-431

Brasington, D. M. and Sarama Jr, R. F. (2008), "Deed types, house prices and mortgage interest rates", Real Estate Economics, Vol. 36 No. 3, pp. 587-610.

Byrne, M. and Norris, M. (2018), "Procyclical social housing and the crisis of Irish housing policy: marketisation, social housing and the property boom and bust", Housing Policy Debate, Vol. 28 No. 1, pp. 50-63.

Campbell, J. Y. and Shiller, R. (1988), "The dividend price ratio and expectations of future dividends and discount factors", The Review of Financial Studies, Vol. 1 No. 3, pp. 195-288.

Campbell, S. D., M. Davis., J. G. Gallin and R. F. Martin. (2009), "What moves housing markets: a variance decomposition of the rent-price ratio", Journal of Urban Economics, Vol. 66 No. 2, pp. 90-102.

Chan, H.L. and Woo, K.Y. (2013), "Studying the dynamic relationships between residential property prices, stock prices and GDP: lessons from Hong Kong”, Journal of Housing Research, Vol. 22 No. 1, pp. 75-89.

Clark, S. and Lomax, N. (2019), "Rent/price ratio for English housing sub-markets using matched sales and rental data", American Real Estate Association, pp. 1-12.

Colwell, P. F. (2002), Tweaking the DiPasquale- Wheaton Model, Journal of Housing Economics, Vol. 11 No. 1, pp. 24-39.

Coulson, N. E. and Kim, M. S. (2000), "Residential investment, non-residential investment and GDP, Real Estate Economics", Vol. 28 No. 2, pp. 233-247.

Cronin, D. and McQuinn, K. (2016), "Credit availability, macroprudential regulations and the house price-to-rent ratio", Journal of Policy Modeling, Vol. 38 No. 5, pp. 971-984.

Damen, S., Vastmans, F. and Buyst, E. (2016), "The effect of mortgage interest deduction and mortgage characteristics on house prices", Journal of Housing Economics, Vol. 34, pp. 15-29.

Department for Communities (2017), Northern Ireland Housing Statistics 2017-18. (available at: https://www.communities-ni.gov.uk/publications/northern-ireland-housing-statistics-2017-18) 
Dickey, D. A., Jansen, D. W. and Thornton, D.L. (1991), "A primer on cointegration with and application to money and income", Federal Reserve Bank of St. Louis Review, March/April, pp. $58-79$.

Dipasquale, D. and Wheaton, W. C. (1992), "The markets for real estate assets and space: a conceptual framework", Real Estate Economics, Vol. 20, 181-198.

Downing, C., Stanton, R. and Wallace, N. (2005), "An empirical test of a two-factor mortgage valuation model: how much do house prices matter?", Real Estate Economics, Vol. 4, pp. 681-710.

Enders, W. (1995), Applied Econometric Time Series, Wiley, New York, USA.

Engle, R. F. and Granger, C. W. J. (1987), "Cointegration and error correction: representation, estimation and testing", Econometrica, Vol. 55 No. 2, pp. $251-276$.

Feng-jun, W. W. L. Z. (2011), "Urbanization and house price-to-rent ratio: based on panel data of 35 large or medium cities", Finance and Trade Research, Vol. 5.

Fisher, I. (1930), The theory of interest as determined by impatience to spend income and opportunity to invest it, New York, the Macmillan Company.

Frey, J. and Grey, P. (2010), "Northern Ireland's housing market: The prospects for recovery, the role of mortgage markets and the perspective in an era of public expenditure constraint", Housing Finance International (Online), Vol. 24 No. 4, pp. 29-36.

Ghosh, A. (1995), "The hedging effectiveness of ECU futures contracts: forecasting evidence from an error correction model", The Financial Review, Vol. 30 No. 3, pp. 567-581.

Gilbukh, S., Haughwout, A. and Tracy, J. (2017), "The price to rent ratio: a macroprudential application", Working Paper (Available at www.atlantafed.org/-/media/documents/ news/conferences/2017/1201-real-estate-industry-forum/papers/Tracy_Price-rent-ratios.pdf)

Granger, C. W. J. (1988), "Some recent developments in a concept of causality", Journal of Econometrics, Vol. 39 No. 1-2, 199-211.

Granger, C. W. J. and Newbold, P. (1974), "Spurious regressions in econometrics", Journal of Econometrics, Vol. 2 No. 2, pp. 111-120.

Granziera, E. and Kozicki, S. (2015), "House price dynamics: fundamentals and expectations", Journal of Economic Dynamics and Control, Vol. 60, pp. 152-165.

Green, R. K. (1997), "Follow the leader: how changes in residential and non-residential investment predict changes in GDP", Real Estate Economics, Vol. 25 No. 2, pp. 253-270.

Green, R. K. (2002), "Stock prices and house prices in California: new evidence of a wealth effect?", Regional Science and Urban Economics, Vol. 32 No. 6, pp. 775-783.

Guo, F. and Huang, Y. S. (2010), "Does "hot money" drive China's real estate and stock markets?", International Review of Economics and Finance, Vol. 19 No. 3, pp. 452-466.

Haran, M., Berry, J., Davis, P., Lo, D., MacIntyre, J. and McCord. (2019). Creating a more effective and sustainable housing development model for Northern Ireland", Forum for Better Housing NI (October), the Housing Supply Forum, Lloyds Banking Group.

Hartmann, P. (2015), "Real estate markets and macroprudential policy in Europe", Journal of Money, Credit and Banking, Vol. 47 No. S1, pp. 69-80.

Hill, R. J. and Syed, I. A. (2016), "Hedonic price-rent ratios, user cost, and departures from equilibrium in the housing market", Regional Science and Urban Economics, Vol. 56, pp. 60-72.

Himmelberg, C, Mayer, C. and Sinai, T. (2005), "Assessing high house prices: bubbles, fundamentals and misperceptions", Journal of Economic Perspectives, Vol. 19, pp. 67-92.

Hubbard, R. G. and Mayer, C. J. (2009), "The mortgage market meltdown and house prices", The BE Journal of Economic Analysis and Policy, Vol. 9 No. 3, Article 8.

Hulse, K. and Yates, J. (2017), "A private rental sector paradox: unpacking the effects of urban restricting on housing market dynamics", Housing Studies, Vol. 21 No. 3, pp. 253-270.

Johansen, S. (1991), Estimation and Hypotheses Testing of Co-integration Vectors in Gaussian Vector Autoregressive Models, Econometrica, Vol. 59 No. 6, pp. 1551 - 1580.

Johansen, S. (1995), Likelihood-based Inference in Cointegrated Vector Autoregressive Models, Oxford University Press, Oxford, U.K. 
Juselius, K., Moller, N. F. and Tarp, F. (2013), The long-run impact of foreign aid in 36 African countries: Insights from multivariate time series analysis, Oxford Nulletin of Economics and Statistics, Vol. 76 No. 2, pp. 153- 184.

Kakes, J. and Van Den End, J. W. (2004), "Do stock prices affect house prices? Evidence for the Netherlands", Applied Economics Letters, Vol. 11 No. 12, pp.741-744.

Kim, T. and H. Lim. (2014), "Understanding the Irish price-rent ratio: an unobserved component approach", Applied Economics Letters, Vol. 21 No. 12., pp. 836-841.

Kishor, N. K. and Morley, J. (2015), "What factors drive the price-rent ratio for the housing market? A modified present-value analysis", Journal of Economic Dynamics and Control, Vol. 58, pp. 235-249.

Lee, C. and Park, K. (2018), "Analysing the rent-to-price ratio for the housing market at the microspatial scale”, International Journal of Strategic Property Management, Vol. 22 No. 22, pp. 223233.

Leung, C. K. Y., Leong, Y. C. F. and Wong, S. K. (2006), "Housing price dispersion: An empirical investigation", Journal of Real Estate Finance and Economics, Vol. 32, pp.357-385.

Lo, D., McCord, M., McCord, J., Davis, P. and Haran, M. (2021), "Rent or buy, what are the odds?: Analysing the price-to-rent ratio for housing types within the Northern Ireland housing market", International Journal of Housing Markets and Analysis (Forthcoming).

Ludwig, A. and Sløk, T. (2004), "The relationship between stock prices, house prices and consumption in OECD countries". Topics in Macroeconomics, Vol. 4 No. 1.

Masih, A. M. M. and Masih, R. (1997), "On the temporal causal relationship between energy consumption, real income, and prices: some new evidence from Asian-energy dependent NICs based on multivariate cointegration / vector error correction approach", Journal of Policy Modeling, Vol. 19 No. 4, pp. 417-440.

McCord, M, Davis, P.T., Haran, M., McIlhatton, D. and McCord, J. (2014), "Understanding rental prices in the UK: a comparative application of spatial modelling approaches", International Journal of Housing Markets and Analysis, Vol. 7 No. 1, pp.98-128.

McCord, M., McGreal, S., Berry, J., Haran, M. and Davis, P. (2011), "The implications of mortgage finance on housing market affordability", International Journal of Housing Markets and Analysis. Vol. 4 No. 4, pp. 394-417.

McCord, M., Lo, D., McCord, J., Davis, P. and Haran, M. (2019), "Measuring the cointegration of housing types in Northern Ireland", Journal of Property Research, Vol. 36 No. 4, pp. 343-366.

McQuinn, K., and O'Reilly, G. (2008), “Assessing the role of income and interest rates in determining house prices", Economic Modelling, Vol. 25 No. 3, pp. 377-390.

Muellbauer, J. and Murphy, A. (1997), "Booms and bursts in the UK housing market", The Economic Journal, Vol. 107 No. 445, pp. 1701-1727.

Newell, G. and Chau, K. W. (1996), "Linkages between direct and indirect property performance in Hong Kong", Journal of Property Finance, Vol. 7 No. 4, pp. 9 - 20.

NISRA (2020), Mid-year Population Estimates - Statistical Bulletin 2020, Northern Ireland Statistics and Research Agency. (Available at www.nisra.gov.uk/sites/nisra.gov.uk/files/publications/MYE20Bulletin.pdf)

Okunev, J. Wilson, P. and Zurbruegg, R. (2000), “The Causal Relationship between real estate and stock markets", Journal of Real Estate Finance and Economics, Vol 21 No. 3, pp. 251-261.

Otto, G. (2007), "The growth of house prices in Australian capital cities: what do economic fundamentals explain?", Australian Economic Review, Vol. 40 No. 3, pp. 225- 238.

Patterson, K. (2000), An Introduction to Applied Econometrics: A Time Series Approach, Palgrave, New York.

Rae, J. (1834), "Statement of some new principles on the subject of political economy", McMaster University Archive for the History of Economic Thought.

Schwartz, A. (2011), "The credit crunch and subsidized low-income housing: The UK and US experience compared", Journal of Housing and the Built Environment, Vol. 26 No. 3, pp. 353 374. 
Sommer, K., Sullivan, P. and Verbrugge, R. (2010), "Run-up in the house price-rent ratio: how much can be explained by fundamentals?", US Department of Labor, Bureau of Labor Statistics, Office of Prices and Living Conditions.

Thomas, R. L. (1997), Modern Econometrics: An Introduction. Addison-Wesley, Wokingham, U.K., pp. 378-379.

Toda, H. and Phillips, P. (1993), "Vector autoregressions and causality", Econometrica, Vol. 61 No. 6, pp. $1367-1394$.

Tsai, I. C. and Peng, C, W. (2011), "Bubbles in the Taiwan housing market: the determinants and effects, Habitat International, Vol. 35, pp. 379 - 390.

Wu, F. X. and Jiang, F. Z. (2012), "Price-to-rent ratio housing price-to-income ratio and real estate market regulation: An empirical analysis based on the comparison between regional market differences", Contemporary Finance and Economics, Vol. 6, pp. 80-88.

$\mathrm{Xu}$, J. J. and Ge, Y. (2011), "The functional mechanism of expected housing price to rent ratio: an empirical research based on 35 large and medium cities, Economic Survey, Vol. 4, pp.51-55.

Zhai, D., Shang, Y., Wen, H. and Ye, J. (2018), "Housing price, housing rent, and rent-price ratio: Evidence from 30 cities in China", Journal of Urban Planning and Development, Vol 144, No. 11. 04017026

Zou, G. and Chau, K. W. (2020), "Effects of international crude oil prices on energy consumption in China”, Energies, Vol. 13, 3891 . 
Tables and Figures

\section{Table 1: Summary of key relevant research studies in the literature}

\begin{tabular}{|c|c|c|c|}
\hline Author(s) & Sample & Findings & $\begin{array}{l}\text { Key determinants of housing price } \\
\text { and/or the housing P-t-R ratio }\end{array}$ \\
\hline Okunev et al. (2000) & $\begin{array}{l}\text { The United States } \\
(1972-1998)\end{array}$ & $\begin{array}{l}\text { By using non-linear causality tests, a strong unidirectional relationship } \\
\text { running from the S \& P stock market to the real estate market was detected. }\end{array}$ & Stock market performance \\
\hline $\begin{array}{l}\text { Himmelberg et al. } \\
(2005)\end{array}$ & USA (1980-2004) & $\begin{array}{l}\text { An unexpected increase in real interest rates could result in rising housing } \\
\text { costs, which could in turn reduce housing demand, slowing the growth of } \\
\text { property prices and likely leading to a reduction in price. }\end{array}$ & Mortgage rates \\
\hline Otto (2008) & Australia (1986-2004) & $\begin{array}{l}\text { Mortgage rates were the most consistently important influence on the } \\
\text { growth rate of house prices across the eight sample capital cities in } \\
\text { Australia. On the other hand, inflation appeared to affect only the markets } \\
\text { of Sydney, Brisbane, Perth and Canberra. }\end{array}$ & $\begin{array}{l}\text { Mortgage rates, employment and } \\
\text { inflation. }\end{array}$ \\
\hline Campbell et al. (2009) & USA (1975-2007) & $\begin{array}{l}\text { Housing premia are variable and forecastable and account for a large } \\
\text { percentage of the variation of the P-t-R ratio at both the national and local } \\
\text { levels, of which interest rates are a key determinant. }\end{array}$ & Interest rates \\
\hline Guo and Huang (2010) & China (1997-2008) & $\begin{array}{l}\text { Foreign speculative funds aggravated short term property prices and } \\
\text { increased the volatility of the property market. }\end{array}$ & Foreign investments (short term) \\
\hline Sommer et al. (2010) & $\begin{array}{l}\text { The United States } \\
(1995-2005)\end{array}$ & $\begin{array}{l}\text { More than } 50 \% \text { of the increase in the US resident property P-t-R ratio } \\
\text { between the investigation period was attributable to lower interest rates, } \\
\text { less restrictive lending requirements and higher income levels. }\end{array}$ & $\begin{array}{l}\text { Interest rates, income and the lending } \\
\text { environment. }\end{array}$ \\
\hline Tsai and Peng (2011) & Taiwan (1989-2007) & $\begin{array}{l}\text { Housing bubble, measured in terms of price and rent, was caused by and/or } \\
\text { associated with mortgage rates, inflation and (expansionary) monetary } \\
\text { policy. }\end{array}$ & $\begin{array}{l}\text { Mortgage rate, money supply, inflation } \\
\text { and economic growth rate. }\end{array}$ \\
\hline Kim and Lim (2014) & Ireland (1976-2012) & $\begin{array}{l}\text { P-t-R ratio was affected byby the expected housing premium. On the other } \\
\text { hand, real interest rates and expected rental growth were less significant } \\
\text { factors driving the variation of the ratio. }\end{array}$ & $\begin{array}{l}\text { Expected housing price return, interest } \\
\text { rates and expected rental growth. }\end{array}$ \\
\hline $\begin{array}{l}\text { Kishor and Morley } \\
(2015)\end{array}$ & $\begin{array}{l}\text { The United States } \\
(1975-2014)\end{array}$ & $\begin{array}{l}\text { By subjecting the analysis to tests at both national and metropolitan area } \\
\text { levels, the study demonstrated that mortgage interest rates, housing supply } \\
\text { elasticity and variation in the expected housing returns are key } \\
\text { determinants of the price-to-rent ratio. }\end{array}$ & $\begin{array}{l}\text { Mortgage interest rates, housing } \\
\text { supply elasticity and expected housing } \\
\text { return. }\end{array}$ \\
\hline $\begin{array}{l}\text { Cronin and McQuinn } \\
(2016)\end{array}$ & Ireland (1980-2014) & $\begin{array}{l}\text { A reduction in the loan-to-value (LTV) ratio increases demand for rental } \\
\text { accommodation, leading to higher rents for a given property price level. }\end{array}$ & LTV ratios \\
\hline Gilbukh et al. (2017) & USA (1985-2016) & $\begin{array}{l}\text { A P-t-R-based housing finance macroprudential tool was designed by } \\
\text { accounting for mortgage interest, down-payment, risk-free interest rates } \\
\text { and inflation, showing that the distribution of P-t-R ratios shifted up } \\
\text { considerably during a period of property market boom. }\end{array}$ & $\begin{array}{l}\text { Mortgage interest, down-payment, } \\
\text { risk-free interest rates and inflation. }\end{array}$ \\
\hline $\begin{array}{l}\text { Bahmani-Oskooee and } \\
\mathrm{Wu}(2018)\end{array}$ & $\begin{array}{l}18 \text { OECD countries } \\
(1994-2016)\end{array}$ & $\begin{array}{l}\text { Housing prices Granger-caused exchange rates in Australia, Belgium, } \\
\text { Ireland and Portugal, and the opposite causality was observed in Canada, } \\
\text { Germany, Greece, South Korea and the U.S. }\end{array}$ & Exchange rates \\
\hline Lee and Park (2018) & South Korea (2016) & $\begin{array}{l}\text { By using Integrated Nested Laplace Approximation algorithm, the study } \\
\text { revealed that at individual property level, interest rates and physical } \\
\text { attributes of a dwelling determine the price-to-rent ratio. }\end{array}$ & $\begin{array}{l}\text { Interest rates and property-level } \\
\text { attributes }\end{array}$ \\
\hline Zhai et al. (2018) & China (2008-2013) & $\begin{array}{l}\text { The amount of residential housing investment seemed to exhibit a strong } \\
\text { positive impact upon the price-to-rent ratio, whilst the opposite was } \\
\text { observed for factors such as GDP, housing price expectation, per capita } \\
\text { disposable income. }\end{array}$ & $\begin{array}{l}\text { Volume of residential property } \\
\text { investment and GDP }\end{array}$ \\
\hline Borgersen (2020) & Norway (2020) & $\begin{array}{l}\text { The linkage between LTV and P-t-R is context specific, with the return } \\
\text { arising from leverage highly dependent on the relationship between } \\
\text { property price growth and mortgage interest rate. }\end{array}$ & $\begin{array}{l}\text { LTV ratio, interest rates and mortgage } \\
\text { interest rates. }\end{array}$ \\
\hline
\end{tabular}


Northern Ireland Composite Economic Index (NICEI) Northern Ireland Composite Economic Index (Construction) New housing investment $\left(N H_{t}\right)$

New private housing investment $\left(\mathrm{NH}_{\mathrm{p}}\right)$

Mortgage Interest Rates (MIR)

FTSE 100 Index (FTSE)

(FTSE_GROWTH)

Exchange

EUR/GBP)

(USD/GBP)

Money supply (M2)

Money supply (M3)
Measured by the two-year household variable mortgage rate in the U.K., which represents the cost of capital or borrowing for prospective purchasers

The Index captures the performance of the largest 100 qualifying constituent companies (in the UK) by market capitalisation

Proxied by Consumer Price Index (CPI), measures the general price level of goods and services typically purchased by the households in the U.K.

\section{The}

Rate Currency exchange rates between the Euro and British pound

Currency exchange rates between the Dollar and British pound

The sum of cash, checking deposits, saving deposits, mutual funds, money market securities and time deposits

The sum of cash, checking deposits, saving deposits, mutual funds, money market securities and time deposits, institutional money market funds, short term repurchase agreements and other larger liquid assets such as marketable securities.

Quarterly index based on the economic performance of various sectors of the economy including construction, public services, manufacturing and private services.

Quarterly Index based on the economic performance of the construction sector

The level of total new housing stock represented by the number of domestic dwellings recorded in Northern Ireland at the beginning of each financial year.

The level of total new private housing stock represented by the number of domestic dwellings recorded in Northern Ireland at the beginning of each financial year.
Federal

Reserve

Bank of St

Louis.

FTSE

FTSE

Yahoo

Yahoo

ONS

ONS

NISRA

NISRA

NISRA

NISRA

Table 3: Descriptive statistics of the four property types

\begin{tabular}{lcccc}
\hline Property Type & $\begin{array}{c}\text { Average Price } \\
(\mathfrak{(})\end{array}$ & $\begin{array}{c}\text { Average Rent } \\
(\mathfrak{f})\end{array}$ & Percent & N \\
\hline Detached & 207,478 & 10,542 & 3.46 & 1,489 \\
Semi-detached & 165,227 & 8,194 & 12.3 & 5,278 \\
Terrace & 98,469 & 6,852 & 42.5 & 18,266 \\
Apartment & 130,249 & 7,904 & 41.7 & 17,940 \\
All & 150,890 & 7,723 & 100 & 42973 \\
\hline
\end{tabular}

Table 4: Correlation between the P-t-R and the macroeconomic variables

\begin{tabular}{lccccc}
\hline & \multicolumn{5}{c}{ Price to Rent Ratio } \\
\hline & All & Detached & $\begin{array}{c}\text { Semi- } \\
\text { detached }\end{array}$ & Terraced & Apartment \\
\hline Inflation (CPI) & -0.18 & -0.09 & 0.07 & -0.40 & -0.13 \\
FTSE & -0.06 & -0.43 & -0.04 & 0.10 & -0.14 \\
\hline
\end{tabular}




\begin{tabular}{lccccc}
\hline EUR/GBP & 0.26 & 0.43 & 0.00 & 0.05 & -0.09 \\
USD/GBP & 0.37 & 0.61 & 0.30 & 0.05 & 0.02 \\
M2 & -0.20 & -0.36 & -0.10 & 0.00 & 0.09 \\
M3 & -0.22 & -0.34 & -0.12 & 0.01 & -0.02 \\
Mortgage interest rate ${ }^{\mathrm{a}}$ (MIR) & 0.09 & 0.22 & 0.11 & -0.02 & -0.06 \\
NICEI & -0.24 & -0.39 & -0.14 & -0.04 & 0.30 \\
NICEI (construction) & -0.03 & -0.27 & 0.10 & 0.10 & 0.16 \\
Total new housing investment & -0.11 & -0.24 & -0.03 & 0.08 & 0.06 \\
Total new pri. housing investment & -0.08 & -0.21 & 0.01 & 0.10 & 0.03 \\
\hline Semi-detached & & 0.36 & & & \\
Terraced & & 0.10 & 0.25 & & \\
Apartment & -0.48 & -0.29 & -0.09 & \\
\hline
\end{tabular}

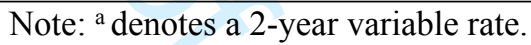

Table 5: Results of Augmented Dickey Fuller tests

\begin{tabular}{lll}
\hline Description & Variable & Stationary* \\
\hline Aggregate price to rent ratio & $P R_{A}$ & At first difference \\
Price to rent ratio of the detached submarket & $P R_{d}$ & At first difference \\
Price to rent ratio of the semi-detached submarket & $P R_{s}$ & At first difference \\
Price to rent ratio of the terraced submarket & $P R_{t}$ & At first difference \\
Price to rent ratio of the apartment submarket & $P R_{a}$ & At first difference \\
Inflation rate $(\mathrm{CPI})$ & $\mathrm{CPI}$ & At second difference \\
FTSE Index 100 & FTSE & At first difference \\
Exchange rate of EUR/GBP & EUR/GBP & At level \\
Exchange rate of EUR/USD & EUR/USD & At first difference \\
Growth rate of M2 money supply & M2 & At first difference \\
Growth rate of M3 money supply & M3 & At second difference \\
2-year variable mortgage interest rate & MIR & At level \\
NICEI Index & NICEI & At first difference \\
NICEI Construction Index & $N I C E I_{c}$ & At first difference \\
Total new housing growth & $N H_{t}$ & At level \\
Total new private housing growth & $N H_{p}$ & At level \\
\hline *Determined by the $5 \%$ statistical level. Full results are available upon request. &
\end{tabular}

Table 6: Results of Cointegration Tests

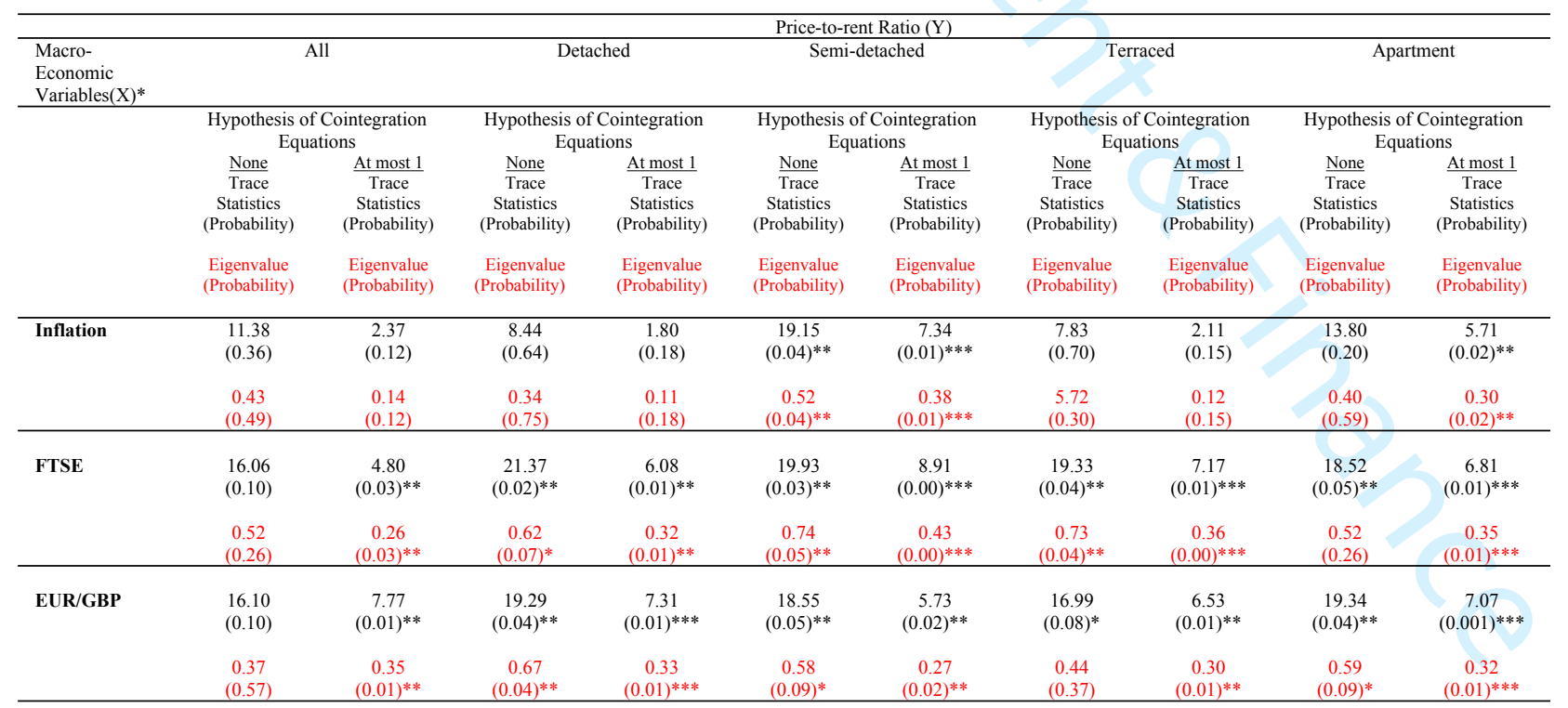




\begin{tabular}{|c|c|c|c|c|c|c|c|c|c|c|}
\hline \multirow[t]{2}{*}{ USD/GBP } & $\begin{array}{c}26.26 \\
(0.00)^{* * *}\end{array}$ & $\begin{array}{c}6.69 \\
(0.01)^{* * *}\end{array}$ & $\begin{array}{c}4.79 \\
(0.16)\end{array}$ & $\begin{array}{c}4.79 \\
(0.03)^{* *}\end{array}$ & $\begin{array}{c}30.85 \\
(0.00)^{* * *}\end{array}$ & $\begin{array}{c}11.46 \\
(0.00)^{* * *}\end{array}$ & $\begin{array}{c}23.64 \\
(0.01)^{* * *}\end{array}$ & $\begin{array}{c}6.28 \\
(0.01)^{* *}\end{array}$ & $\begin{array}{c}30.00 \\
(0.00)^{* * *}\end{array}$ & $\begin{array}{c}5.70 \\
(0.02)^{* *}\end{array}$ \\
\hline & $\begin{array}{c}0.68 \\
(0.02)^{* *}\end{array}$ & $\begin{array}{c}0.33 \\
(0.01) * * * 2 \\
\end{array}$ & $\begin{array}{c}0.43 \\
(0.43) \\
\end{array}$ & $\begin{array}{c}0.26 \\
(0.03)^{* *} \\
\end{array}$ & $\begin{array}{c}0.68 \\
(0.02)^{* *} \\
\end{array}$ & $\begin{array}{c}0.49 \\
(0.00)^{* * *}\end{array}$ & $\begin{array}{c}0.64 \\
(0.05) * * 2 \\
\end{array}$ & $\begin{array}{c}0.31 \\
(0.01)^{* * 2} \\
\end{array}$ & $\begin{array}{c}0.76 \\
(0.00)^{* * *} \\
\end{array}$ & $\begin{array}{c}0.28 \\
(0.02)^{* *}\end{array}$ \\
\hline \multirow[t]{2}{*}{ M2 growth } & $\begin{array}{l}14.45 \\
(0.16)\end{array}$ & $\begin{array}{c}5.49 \\
(0.02)^{* *}\end{array}$ & $\begin{array}{c}24.14 \\
(0.01)^{* * *}\end{array}$ & $\begin{array}{c}6.31 \\
(0.01)^{* *}\end{array}$ & $\begin{array}{c}16.93 \\
(0.08)^{*}\end{array}$ & $\begin{array}{c}7.87 \\
(0.01)^{* * *}\end{array}$ & $\begin{array}{c}17.13 \\
(0.07)^{*}\end{array}$ & $\begin{array}{c}6.64 \\
(0.01)^{* *}\end{array}$ & $\begin{array}{c}16.72 \\
(0.08)^{*}\end{array}$ & $\begin{array}{c}5.42 \\
(0.02)^{* *}\end{array}$ \\
\hline & $\begin{array}{c}9.43 \\
(0.50) \\
\end{array}$ & $\begin{array}{c}0.29 \\
(0.02)^{* *} \\
\end{array}$ & $\begin{array}{c}0.67 \\
(0.04)^{* *}\end{array}$ & $\begin{array}{c}0.33 \\
(0.01) * * \\
\end{array}$ & $\begin{array}{c}0.43 \\
(0.49) \\
\end{array}$ & $\begin{array}{c}0.39 \\
(0.01)^{* * *} \\
\end{array}$ & $\begin{array}{c}0.48 \\
(0.36) \\
\end{array}$ & $\begin{array}{c}0.34 \\
(0.01)^{* *} \\
\end{array}$ & $\begin{array}{c}0.51 \\
(0.29) \\
\end{array}$ & $\begin{array}{c}0.29 \\
(0.02)^{* *}\end{array}$ \\
\hline \multirow[t]{2}{*}{ M3 growth } & $\begin{array}{c}30.88 \\
(0.00)^{* * *}\end{array}$ & $\begin{array}{c}4.97 \\
(0.03)^{* *}\end{array}$ & $\begin{array}{c}40.90 \\
(0.00)^{* * *}\end{array}$ & $\begin{array}{c}5.79 \\
(0.02)^{* *}\end{array}$ & $\begin{array}{c}30.84 \\
(0.00)^{* * *}\end{array}$ & $\begin{array}{c}6.30 \\
(0.01)^{* *}\end{array}$ & $\begin{array}{c}36.11 \\
(0.00)^{* * *}\end{array}$ & $\begin{array}{c}9.14 \\
(0.00)^{* * *}\end{array}$ & $\begin{array}{c}33.81 \\
(0.00)^{* * *}\end{array}$ & $\begin{array}{c}8.88 \\
(0.00)^{* * *}\end{array}$ \\
\hline & $\begin{array}{c}0.82 \\
(0.00)^{* * *} \\
\end{array}$ & $\begin{array}{c}0.28 \\
(0.03) * * 2 \\
\end{array}$ & $\begin{array}{c}0.90 \\
(0.00)^{* * *} \\
\end{array}$ & $\begin{array}{c}0.32 \\
(0.02)^{* * 2} \\
\end{array}$ & $\begin{array}{c}0.81 \\
(0.00)^{* * * *} \\
\end{array}$ & $\begin{array}{c}0.34 \\
(0.01)^{* * 2} \\
\end{array}$ & $\begin{array}{c}0.83) \\
(0.00)^{* * *}\end{array}$ & $\begin{array}{c}0.46 \\
(0.00)^{* * * 2} \\
\end{array}$ & $\begin{array}{c}0.81 \\
(0.00)^{* * *} \\
\end{array}$ & $\begin{array}{c}0.45 \\
(0.00)^{* * * 2} \\
\end{array}$ \\
\hline \multirow[t]{2}{*}{ Mortgage IR } & $\begin{array}{c}26.92 \\
(0.00)^{* * *}\end{array}$ & $\begin{array}{c}8.81 \\
(0.00)^{* * *}\end{array}$ & $\begin{array}{c}20.89 \\
(0.02)^{* *}\end{array}$ & $\begin{array}{c}7.14 \\
(0.00)^{* * *}\end{array}$ & $\begin{array}{c}33.35 \\
(0.00)^{* * *}\end{array}$ & $\begin{array}{c}8.66 \\
(0.00)^{* * *}\end{array}$ & $\begin{array}{c}33.06 \\
(0.00)^{* * *}\end{array}$ & $\begin{array}{c}12.27 \\
(0.00)^{* * *}\end{array}$ & $\begin{array}{c}21.79 \\
(0.02)^{* *}\end{array}$ & $\begin{array}{c}8.20 \\
(0.00)^{* * *}\end{array}$ \\
\hline & $\begin{array}{c}0.63 \\
(0.04)^{* * 2} \\
\end{array}$ & $\begin{array}{c}0.39 \\
(0.00) * * * 2 \\
\end{array}$ & $\begin{array}{c}0.60 \\
(0.08)^{*} \\
\end{array}$ & $\begin{array}{c}0.33 \\
(0.01)^{* *} \\
\end{array}$ & $\begin{array}{c}0.75 \\
(0.00)^{* * *} \\
\end{array}$ & $\begin{array}{c}0.38 \\
(0.00)^{* * *} \\
\end{array}$ & $\begin{array}{c}0.68 \\
(0.01)^{* *} \\
\end{array}$ & $\begin{array}{c}0.49 \\
(0.00)^{* * *} \\
\end{array}$ & $\begin{array}{c}0.63 \\
(0.05)^{*} \\
\end{array}$ & $\begin{array}{c}0.37 \\
(0.00)^{* * *} \\
\end{array}$ \\
\hline \multirow[t]{2}{*}{ NICEI } & $\begin{array}{c}26.35 \\
(0.00)^{* * *}\end{array}$ & $\begin{array}{c}8.10 \\
(0.00)^{* * *}\end{array}$ & $\begin{array}{c}20.38 \\
(0.03)^{* *}\end{array}$ & $\begin{array}{c}5.19 \\
(0.02)^{* *}\end{array}$ & $\begin{array}{c}34.78 \\
(0.00)^{* * *}\end{array}$ & $\begin{array}{c}10.54 \\
(0.00)^{* * *}\end{array}$ & $\begin{array}{c}36.07 \\
(0.00)^{* * *}\end{array}$ & $\begin{array}{c}10.17 \\
(0.00)^{* * *}\end{array}$ & $\begin{array}{c}38.48 \\
(0.00)^{* * *}\end{array}$ & $\begin{array}{c}7.57 \\
(0.01)^{* * *}\end{array}$ \\
\hline & $\begin{array}{c}0.66 \\
(0.03)^{* *} \\
\end{array}$ & $\begin{array}{c}0.38 \\
(0.00) \\
\end{array}$ & $\begin{array}{c}0.59 \\
(009)^{*}\end{array}$ & $\begin{array}{c}0.26 \\
(0.02)^{* *} \\
\end{array}$ & $\begin{array}{c}0.76 \\
(0.00)^{* * *}\end{array}$ & $\begin{array}{c}0.46 \\
(0.00)^{* * *}\end{array}$ & $\begin{array}{c}0.78 \\
(0.00)^{* * *}\end{array}$ & $\begin{array}{c}0.45 \\
(0.00)^{* * *}\end{array}$ & $\begin{array}{c}0.84 \\
(0.00)^{* * *} \\
\end{array}$ & $\begin{array}{c}0.36 \\
(0.01)^{* * *} \\
\end{array}$ \\
\hline \multirow[t]{2}{*}{$\begin{array}{l}\text { NICEI } \\
\text { (Construction) }\end{array}$} & $\begin{array}{c}23.45 \\
(0.00)^{* * *}\end{array}$ & $\begin{array}{c}6.04 \\
(0.01)^{* *}\end{array}$ & $\begin{array}{c}23.67 \\
(0.01)^{* * *}\end{array}$ & $\begin{array}{c}5.43 \\
(0.02)^{* *}\end{array}$ & $\begin{array}{c}29.57 \\
(0.00)^{* * *}\end{array}$ & $\begin{array}{c}11.84 \\
(0.00)^{* * *}\end{array}$ & $\begin{array}{c}29.02 \\
(0.00)^{* * *}\end{array}$ & $\begin{array}{c}9.81 \\
(0.00)^{* * *}\end{array}$ & $\begin{array}{c}27.42 \\
(0.00)^{* * *}\end{array}$ & $\begin{array}{c}6.61 \\
(0.01)^{* *}\end{array}$ \\
\hline & $\begin{array}{c}0.64 \\
(0.05)^{* *} \\
\end{array}$ & $\begin{array}{c}0.30 \\
(0.01)^{* *}\end{array}$ & $\begin{array}{c}0.66 \\
(0.03)^{* *}\end{array}$ & $\begin{array}{c}0.27 \\
(0.02)^{* *} \\
\end{array}$ & $\begin{array}{c}0.65 \\
(0.04)^{* *} \\
\end{array}$ & $\begin{array}{c}0.50 \\
(0.00)^{* * * *} \\
\end{array}$ & $\begin{array}{c}0.66 \\
(0.04)^{* *} \\
\end{array}$ & $\begin{array}{c}0.44 \\
(0.00)^{* * *} \\
\end{array}$ & $\begin{array}{c}0.71 \\
(0.01)^{* *} \\
\end{array}$ & $\begin{array}{c}0.32 \\
(0.01)^{* *} \\
\end{array}$ \\
\hline \multirow{2}{*}{$\begin{array}{l}\text { Total } \\
\text { housing } \\
\text { growth }\end{array}$} & $\begin{array}{l}15.80 \\
(0.11)\end{array}$ & $\begin{array}{c}5.09 \\
(0.02)^{* *}\end{array}$ & $\begin{array}{l}15.09 \\
(0.14)\end{array}$ & $\begin{array}{c}3.73 \\
(0.05)^{* *}\end{array}$ & $\begin{array}{l}17.40 \\
(0.07)^{*}\end{array}$ & $\begin{array}{c}5.17 \\
(0.02)^{* *}\end{array}$ & $\begin{array}{c}19.81 \\
(0.01)^{* * *}\end{array}$ & $\begin{array}{c}3.84 \\
(0.03)^{* *}\end{array}$ & $\begin{array}{c}22.83 \\
(0.01)^{* *}\end{array}$ & $\begin{array}{c}9.26 \\
(0.00)^{* * *}\end{array}$ \\
\hline & $\begin{array}{c}0.45 \\
(0.34) \\
\end{array}$ & $\begin{array}{c}0.25 \\
(0.02)^{* *}\end{array}$ & $\begin{array}{c}0.47 \\
(0.28) \\
\end{array}$ & $\begin{array}{c}0.19 \\
(0.05)^{*}\end{array}$ & $\begin{array}{c}0.49 \\
(0.23) \\
\end{array}$ & $\begin{array}{c}0.35 \\
(0.02)^{* *} \\
\end{array}$ & $\begin{array}{c}0.62 \\
(0.04)^{* *}\end{array}$ & $\begin{array}{c}0.25 \\
(0.02)^{* *} \\
\end{array}$ & $\begin{array}{c}0.64 \\
(0.03)^{* *} \\
\end{array}$ & $\begin{array}{c}0.40 \\
(0.00)^{* * *} \\
\end{array}$ \\
\hline \multirow[t]{2}{*}{$\begin{array}{l}\text { Private new } \\
\text { housing } \\
\text { growth }\end{array}$} & $\begin{array}{c}25.65 \\
(0.00)^{* * *}\end{array}$ & $\begin{array}{c}9.83 \\
(0.00)^{* * *}\end{array}$ & $\begin{array}{l}15.80 \\
(0.11)\end{array}$ & $\begin{array}{c}6.40 \\
(0.01)^{* *}\end{array}$ & $\begin{array}{l}22.29 \\
(0.01)^{* *}\end{array}$ & $\begin{array}{c}9.70 \\
(0.00)^{* * *}\end{array}$ & $\begin{array}{c}33.42 \\
(0.00)^{* * *}\end{array}$ & $\begin{array}{c}12.84 \\
(0.00)^{* * *}\end{array}$ & $\begin{array}{c}33.41 \\
(0.00)^{* * *}\end{array}$ & $\begin{array}{c}10.30 \\
(0.00)^{* * *}\end{array}$ \\
\hline & $\begin{array}{c}0.61 \\
(0.05) * *\end{array}$ & $\begin{array}{c}0.27 \\
(0.02)^{* *}\end{array}$ & $\begin{array}{c}0.52 \\
(0.15) \\
\end{array}$ & $\begin{array}{c}0.29 \\
(0.01)^{* *}\end{array}$ & $\begin{array}{c}0.67 \\
(0.02)^{* *} \\
\end{array}$ & $\begin{array}{c}0.23 \\
(0.03)^{* *}\end{array}$ & $\begin{array}{c}0.77 \\
(0.00)^{* * *} \\
\end{array}$ & $\begin{array}{c}0.31 \\
(0.01)^{* * *} \\
\end{array}$ & $\begin{array}{c}0.68 \\
(0.02)^{* *} \\
\end{array}$ & $\begin{array}{c}0.45 \\
(0.00)^{* * *} \\
\end{array}$ \\
\hline
\end{tabular}

Note: ${ }^{* * *}$ denotes $1 \%$ statistical sig.; $* * 5 \%$ sig.; ${ }^{*} 10 \%$ sig. Full results are available upon request.

Table 7: Results of Granger Causality Tests

\begin{tabular}{|c|c|c|c|c|c|c|c|c|c|c|}
\hline \multirow{3}{*}{$\begin{array}{l}\text { Macro- } \\
\text { Economic } \\
\text { Variables(X)* } \\
\end{array}$} & \multicolumn{10}{|c|}{ Price-to-rent Ratio (Y) } \\
\hline & \multicolumn{2}{|c|}{ Aggregate } & \multicolumn{2}{|c|}{ Detached } & \multicolumn{2}{|c|}{ Semi-detached } & \multicolumn{2}{|c|}{ Terraced } & \multicolumn{2}{|c|}{ Apartment } \\
\hline & $\begin{array}{l}\text { Short -term } \\
\text { Chi sq. } \\
\text { (Prob) }\end{array}$ & $\begin{array}{l}\text { Long -term } \\
\text { t-statistic } \\
\text { (Prob) }\end{array}$ & $\begin{array}{l}\text { Short -term } \\
\text { Chi sq. } \\
\text { (Prob) }\end{array}$ & $\begin{array}{l}\text { Long -term } \\
\text { t-statistic } \\
\text { (Prob) }\end{array}$ & $\begin{array}{l}\text { Short -term } \\
\text { Chi sq. } \\
\text { (Prob) }\end{array}$ & $\begin{array}{l}\text { Long -term } \\
\text { t-statistic } \\
\text { (Prob) }\end{array}$ & $\begin{array}{l}\text { Short -term } \\
\text { Chi sq. } \\
\text { (Prob) }\end{array}$ & $\begin{array}{l}\text { Long -term } \\
\text { t-statistic } \\
\text { (Prob) }\end{array}$ & $\begin{array}{l}\text { Short -term } \\
\text { Chi sq. } \\
\text { (Prob) }\end{array}$ & $\begin{array}{l}\text { Long -term } \\
\text { t-statistic } \\
\text { (Prob) }\end{array}$ \\
\hline \multicolumn{11}{|l|}{ Inflation } \\
\hline$X->Y$ & $\begin{array}{c}2.83 \\
(0.24)\end{array}$ & - & $\begin{array}{c}3.14 \\
(0.21)\end{array}$ & - & $\begin{array}{l}2.76 \\
(0.25)\end{array}$ & $\begin{array}{c}-2.55 \\
(0.03)^{* *}\end{array}$ & $\begin{array}{c}2.47 \\
(0.29)\end{array}$ & - & $\begin{array}{c}0.33 \\
(0.85)\end{array}$ & - \\
\hline $\mathrm{Y} \rightarrow \mathrm{X}$ & $\begin{array}{c}0.08 \\
(0.96) \\
\end{array}$ & - & $\begin{array}{r}1.76 \\
(0.41) \\
\end{array}$ & - & $\begin{array}{c}3.28 \\
(0.19) \\
\end{array}$ & $\begin{array}{l}-1.30 \\
(0.23) \\
\end{array}$ & $\begin{array}{c}1.65 \\
(0.44) \\
\end{array}$ & - & $\begin{array}{l}1.07 \\
(0.58) \\
\end{array}$ & - \\
\hline \multicolumn{11}{|l|}{ FTSE } \\
\hline$X->Y$ & $\begin{array}{c}1.56 \\
(0.46)\end{array}$ & - & $\begin{array}{c}1.89 \\
(0.39)\end{array}$ & $\begin{array}{c}0.99 \\
(0.35)\end{array}$ & $\begin{array}{c}3.83 \\
(0.15)\end{array}$ & $\begin{array}{l}-1.69 \\
(0.13)\end{array}$ & $\begin{array}{c}1.27 \\
(0.53)\end{array}$ & $\begin{array}{l}-1.20 \\
(0.27)\end{array}$ & $\begin{array}{c}1.80 \\
(0.41)\end{array}$ & $\begin{array}{l}-1.70 \\
(0.13)\end{array}$ \\
\hline $\mathrm{Y}->\mathrm{X}$ & $\begin{array}{c}1.25 \\
(0.54) \\
\end{array}$ & - & $\begin{array}{c}11.16 \\
(0.00)^{* * *}\end{array}$ & $\begin{array}{c}4.94 \\
(0.00)^{* * *}\end{array}$ & $\begin{array}{l}4.08 \\
(0.13) \\
\end{array}$ & $\begin{array}{c}-2.62 \\
(0.03)^{* *}\end{array}$ & $\begin{array}{c}16.33 \\
(0.00)^{* * *}\end{array}$ & $\begin{array}{c}-3.68 \\
(0.01)^{* * *}\end{array}$ & $\begin{array}{l}4.00 \\
(0.14) \\
\end{array}$ & $\begin{array}{c}2.83 \\
(0.02)^{* *}\end{array}$ \\
\hline \multicolumn{11}{|l|}{ EUR/GBP } \\
\hline$X->Y$ & $\begin{array}{c}2.65 \\
(0.30)\end{array}$ & - & $\begin{array}{c}0.96 \\
(0.62)\end{array}$ & $\begin{array}{c}-2.74 \\
(0.02)^{* *}\end{array}$ & $\begin{array}{c}1.07 \\
(0.59)\end{array}$ & $\begin{array}{l}-1.52 \\
(0.16)\end{array}$ & $\begin{array}{c}1.37 \\
(0.50)\end{array}$ & - & $\begin{array}{c}1.19 \\
(0.55)\end{array}$ & $\begin{array}{c}-2.19 \\
(0.05)^{* *}\end{array}$ \\
\hline$Y \rightarrow X$ & $\begin{array}{c}0.27 \\
(0.87) \\
\end{array}$ & - & $\begin{array}{c}0.12 \\
(0.94) \\
\end{array}$ & $\begin{array}{c}0.28 \\
(0.79) \\
\end{array}$ & $\begin{array}{c}1.13 \\
(0.57) \\
\end{array}$ & $\begin{array}{c}-2.46 \\
(0.03)^{* *} \\
\end{array}$ & $\begin{array}{c}0.09 \\
(0.96) \\
\end{array}$ & - & $\begin{array}{c}1.45 \\
(0.48) \\
\end{array}$ & $\begin{array}{c}1.47 \\
(0.17) \\
\end{array}$ \\
\hline \multicolumn{11}{|l|}{ USD/GBP } \\
\hline $\mathrm{X} \rightarrow \mathrm{Y}$ & $\begin{array}{c}4.15 \\
(0.13)\end{array}$ & $\begin{array}{c}-2.61 \\
(0.03)^{* *}\end{array}$ & $\begin{array}{c}1.05 \\
(0.59)\end{array}$ & - & $\begin{array}{c}3.15 \\
(0.21)\end{array}$ & $\begin{array}{c}-1.97 \\
(0.08)^{*}\end{array}$ & $\begin{array}{c}7.52 \\
(0.02)^{* *}\end{array}$ & $\begin{array}{c}-3.05 \\
(0.01)^{* * * *}\end{array}$ & $\begin{array}{c}10.52 \\
(0.01)^{* * *}\end{array}$ & $\begin{array}{c}-3.61 \\
(0.01)^{* * *}\end{array}$ \\
\hline $\mathrm{Y}>\mathrm{X}$ & $\begin{array}{c}0.24 \\
(0.89) \\
\end{array}$ & $\begin{array}{c}0.91 \\
(0.39) \\
\end{array}$ & $\begin{array}{c}1.50 \\
(0.47) \\
\end{array}$ & - & $\begin{array}{c}4.44 \\
(0.11) \\
\end{array}$ & $\begin{array}{c}2.09 \\
(0.07)^{*}\end{array}$ & $\begin{array}{c}0.07 \\
(0.93) \\
\end{array}$ & $\begin{array}{c}0.01 \\
(0.15) \\
\end{array}$ & $\begin{array}{c}4.23 \\
(0.12) \\
\end{array}$ & $\begin{array}{c}-2.38 \\
(0.04)^{* *}\end{array}$ \\
\hline \multicolumn{11}{|l|}{ M2 growth } \\
\hline $\mathrm{X}->\mathrm{Y}$ & $\begin{array}{c}2.86 \\
(0.24)\end{array}$ & - & $\begin{array}{c}0.66 \\
(0.72)\end{array}$ & $\begin{array}{c}0.53 \\
(0.61)\end{array}$ & $\begin{array}{c}1.14 \\
(0.57)\end{array}$ & - & $\begin{array}{c}0.03 \\
(0.98)\end{array}$ & - & $\begin{array}{c}5.65 \\
(0.06) *\end{array}$ & - \\
\hline $\mathrm{Y}>\mathrm{X}$ & $\begin{array}{c}0.01 \\
(0.99) \\
\end{array}$ & - & $\begin{array}{c}6.89 \\
(0.03)^{* *} \\
\end{array}$ & $\begin{array}{c}3.64 \\
(0.01) * * \\
\end{array}$ & $\begin{array}{c}0.55 \\
(0.76) \\
\end{array}$ & - & $\begin{array}{c}0.87 \\
(0.65) \\
\end{array}$ & - & $\begin{array}{c}0.92 \\
(0.63) \\
\end{array}$ & - \\
\hline \multicolumn{11}{|l|}{ M3 growth } \\
\hline $\mathrm{X}->\mathrm{Y}$ & $\begin{array}{c}2.99 \\
(0.22)\end{array}$ & $\begin{array}{l}-1.89 \\
(0.10)\end{array}$ & $\begin{array}{c}2.84 \\
(0.24)\end{array}$ & $\begin{array}{c}1.62 \\
(0.15)\end{array}$ & $\begin{array}{c}3.51 \\
(0.17)\end{array}$ & $\begin{array}{c}-2.33 \\
(0.05)^{* *}\end{array}$ & $\begin{array}{c}11.93 \\
(0.00)^{* * *}\end{array}$ & $\begin{array}{c}-3.17 \\
(0.02)^{* *}\end{array}$ & $\begin{array}{c}2.51 \\
(0.29)\end{array}$ & $\begin{array}{c}-0.65 \\
(0.53)\end{array}$ \\
\hline $\mathrm{Y}->\mathrm{X}$ & $\begin{array}{c}4.45 \\
(0.11) \\
\end{array}$ & $\begin{array}{c}-2.44 \\
(0.04)^{* *}\end{array}$ & $\begin{array}{c}3.02 \\
(0.22) \\
\end{array}$ & $\begin{array}{c}3.02 \\
(0.02) * *\end{array}$ & $\begin{array}{c}6.64 \\
(0.04)^{* *}\end{array}$ & $\begin{array}{l}-1.96 \\
(0.09) *\end{array}$ & $\begin{array}{c}1.09 \\
(0.58) \\
\end{array}$ & $\begin{array}{c}0.17 \\
(0.87) \\
\end{array}$ & $\begin{array}{c}4.28 \\
(0.12)\end{array}$ & $\begin{array}{l}-1.55 \\
(0.16)\end{array}$ \\
\hline \multicolumn{11}{|l|}{ Mortgage IR } \\
\hline $\mathrm{X} \rightarrow \mathrm{Y}$ & $\begin{array}{c}2.84 \\
(0.24)\end{array}$ & $\begin{array}{c}-1.95 \\
(0.08)^{*}\end{array}$ & $\begin{array}{c}3.04 \\
(0.22)\end{array}$ & $\begin{array}{l}-1.51 \\
(0.16)\end{array}$ & $\begin{array}{c}21.77 \\
(0.00)^{* * *}\end{array}$ & $\begin{array}{c}-6.46 \\
(0.00)^{* * *}\end{array}$ & $\begin{array}{c}15.36 \\
(0.00)^{* * *}\end{array}$ & $\begin{array}{c}-4.49 \\
(0.00)^{* * *}\end{array}$ & $\begin{array}{c}6.73 \\
(0.05)^{* *}\end{array}$ & $\begin{array}{c}-3.60 \\
(0.00)^{* * *}\end{array}$ \\
\hline $\mathrm{Y} \rightarrow>\mathrm{X}$ & 2.22 & 1.44 & 11.86 & -3.53 & 2.78 & 0.15 & 10.12 & 1.56 & 6.55 & -1.94 \\
\hline
\end{tabular}




\begin{tabular}{|c|c|c|c|c|c|c|c|c|c|c|}
\hline & $(0.33)$ & $(0.18)$ & $(0.00)^{* * *}$ & $(0.01)^{* *}$ & $(0.25)$ & $(0.89)$ & $(0.01)^{* * *}$ & $(0.15)$ & $(0.04) * *$ & $(0.08) *$ \\
\hline \multicolumn{11}{|l|}{ NICEI } \\
\hline$X->Y$ & $\begin{array}{c}0.17 \\
(0.92)\end{array}$ & $\begin{array}{l}-0.23 \\
(0.83)\end{array}$ & $\begin{array}{l}2.91 \\
(0.23)\end{array}$ & $\begin{array}{c}-2.15 \\
(0.06) *\end{array}$ & $\begin{array}{c}0.43 \\
(0.81)\end{array}$ & $\begin{array}{l}-0.66 \\
(0.52)\end{array}$ & $\begin{array}{c}25.71 \\
(0.00) * * *\end{array}$ & $\begin{array}{c}-5.14 \\
(0.00) * * *\end{array}$ & $\begin{array}{c}4.92 \\
(0.09) *\end{array}$ & -1.56 \\
\hline$Y->X$ & $\begin{array}{c}12.42 \\
(0.00)^{* * *}\end{array}$ & $\begin{array}{c}4.46 \\
(0.00)^{* * * *}\end{array}$ & $\begin{array}{c}0.20 \\
(0.65)\end{array}$ & $\begin{array}{c}2.20 \\
(0.05) * *\end{array}$ & $\begin{array}{l}1.78 \\
(0.41)\end{array}$ & $\begin{array}{l}-1.48 \\
(0.17)\end{array}$ & $\begin{array}{c}1.56 \\
(0.46)\end{array}$ & $\begin{array}{l}-1.04 \\
(0.33)\end{array}$ & $\begin{array}{c}3.84 \\
(0.15)\end{array}$ & $\begin{array}{c}0.58 \\
(0.58)\end{array}$ \\
\hline \multicolumn{11}{|c|}{$\begin{array}{l}\text { NICEI } \\
\text { (Construction) }\end{array}$} \\
\hline$X->Y$ & 2.21 & $\begin{array}{l}-1.62 \\
(0.14)\end{array}$ & $\begin{array}{c}0.88 \\
(0.64)\end{array}$ & $\begin{array}{l}-0.15 \\
(0.88)\end{array}$ & $\begin{array}{l}2.02 \\
(0.36)\end{array}$ & $\begin{array}{l}-0.16 \\
(0.87)\end{array}$ & $\begin{array}{c}0.94 \\
(0.62)\end{array}$ & $\begin{array}{l}-0.20 \\
(0.84)\end{array}$ & $\begin{array}{c}0.52 \\
(0.77)\end{array}$ & $\begin{array}{c}0.74 \\
(0.48)\end{array}$ \\
\hline $\mathrm{Y}->\mathrm{X}$ & $\begin{array}{l}5.47 \\
(0.07)^{*}\end{array}$ & $\begin{array}{c}-4.47 \\
(0.00) * * *\end{array}$ & $\begin{array}{l}17.8 \\
(0.00)^{* * *}\end{array}$ & $\begin{array}{c}-3.66 \\
-0.06 * *\end{array}$ & 9.63 & -4.56 & 1.38 & -4.42 & 7.46 & 4.24 \\
\hline \multicolumn{11}{|c|}{$\begin{array}{ll}\text { Total } & \text { new } \\
\text { housing } & \\
\text { growth } & \end{array}$} \\
\hline $\mathrm{X}->\mathrm{Y}$ & $\begin{array}{l}3.08 \\
(0.21)\end{array}$ & - & $\begin{array}{c}3.30 \\
(0.19)\end{array}$ & - & $\begin{array}{c}0.57 \\
(0.75)\end{array}$ & - & $\begin{array}{c}0.03 \\
(0.98)\end{array}$ & $\begin{array}{c}0.01 \\
(0.99)\end{array}$ & $\begin{array}{c}0.43 \\
(0.81)\end{array}$ & $\begin{array}{c}0.87 \\
(0.40)\end{array}$ \\
\hline $\mathrm{Y}->\mathrm{X}$ & $\begin{array}{l}1.25 \\
(0.54) \\
\end{array}$ & - & $\begin{array}{c}0.77 \\
(0.68) \\
\end{array}$ & - & $\begin{array}{c}1.15 \\
(0.56) \\
\end{array}$ & - & $\begin{array}{c}8.28 \\
(0.02)^{* *}\end{array}$ & $\begin{array}{c}-3.98 \\
(0.00)^{* *}\end{array}$ & $\begin{array}{c}1.52 \\
(0.47) \\
\end{array}$ & $\begin{array}{c}3.11 \\
(0.01)^{* *}\end{array}$ \\
\hline \multicolumn{11}{|c|}{$\begin{array}{ll}\text { Private } & \text { new } \\
\text { housing } & \\
\text { Growth } & \end{array}$} \\
\hline$X->Y$ & $\begin{array}{c}8.91 \\
(0.01)^{* *}\end{array}$ & $\begin{array}{c}-3.98 \\
(0.00)^{* * *}\end{array}$ & $\begin{array}{c}2.27 \\
(0.31)\end{array}$ & - & $\begin{array}{c}6.40 \\
(0.04)^{* *}\end{array}$ & $\begin{array}{c}-3.62 \\
(0.00)^{* * *}\end{array}$ & $\begin{array}{c}5.92 \\
(0.05)^{* *}\end{array}$ & $\begin{array}{c}-3.26 \\
(0.01)^{* *}\end{array}$ & $\begin{array}{c}30.15 \\
(0.00)^{* * *}\end{array}$ & $\begin{array}{c}-7.15 \\
(0.00)^{* * *}\end{array}$ \\
\hline$Y->X$ & $\begin{array}{c}4.03 \\
(0.18)\end{array}$ & $\begin{array}{l}-2.15 \\
(0.06)^{*}\end{array}$ & $\begin{array}{c}0.07 \\
(0.96)\end{array}$ & - & $\begin{array}{c}1.12 \\
(0.57)\end{array}$ & $\begin{array}{l}-0.40 \\
(0.70)\end{array}$ & $\begin{array}{c}5.69 \\
(0.06)^{*}\end{array}$ & $\begin{array}{c}0.15 \\
(0.88)\end{array}$ & $\begin{array}{c}0.80 \\
(0.67)\end{array}$ & $\begin{array}{c}0.37 \\
(0.72)\end{array}$ \\
\hline
\end{tabular}

Notes: $* * *$ denotes $1 \%$ statistical significance; $* * 5 \%$ statistical significance; $* 10 \%$ statistical significance. Full results are available upon request.

Figure 1: Price-to-rent ratios of the four property types (2014Q1 to 2018Q4)

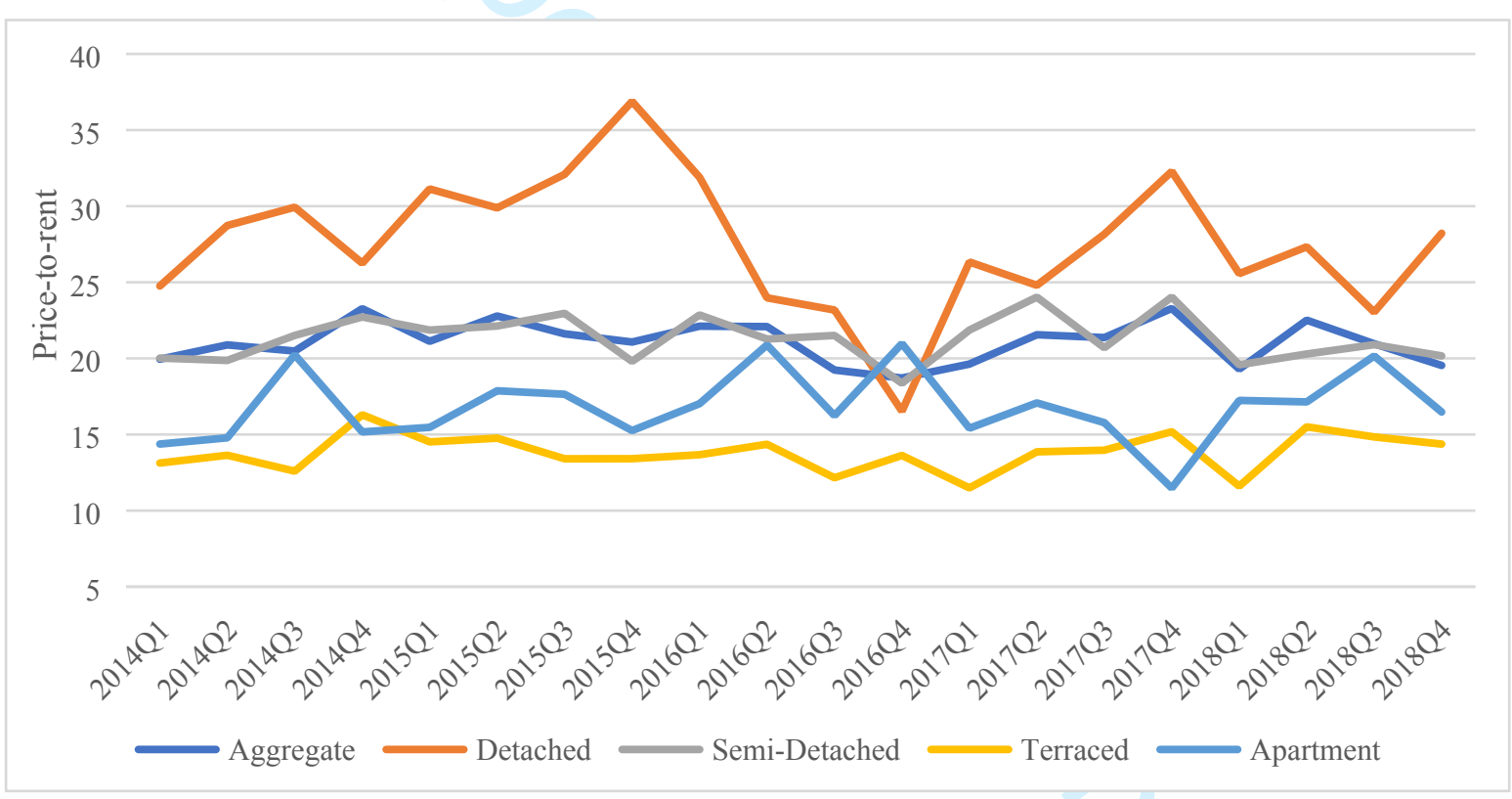


Referee(s)' Comments to Author:

Referee: 1

Recommendation: Major Revision

Comments:

Thank you for the interesting paper. I would like to provide three recommendations:

1. Streamline the literature review to support the variable used in your cointegration analysis

We have attempted to streamline and provide linkages between the variables employed and the extant literature.

2. Give a background to Northern Ireland's housing market during 2014-2018 and why the results from the cointegration analysis make sense.

We have incorporated an overview of the NI housing market over the period and rationalised why the results make sense in the conclusions.

3. Quantify the dynamics between the sub-markets. Could the sub-markets be related?

We have included a discussion on this as previous research in this area has previously tested the sub-market cointegration and S $v$ L-T relationships.

Additional Questions:

1. Originality: Does the paper contain new and significant information adequate to justify publication?: No. Using cointegration analysis, the paper attempts to derive the short-term and long-term relationships between price-to-rent (independent) and a variety of economic and financial components. Neither the methodology nor topic was original. The dataset used spanned from 2014Q1 to 2018Q4, using public secondary data

In revising the paper, we hope this provides more originally. We feel there is a lack of insight as to the relationship between this measure of housing market equilibrium and wider market fundamentals. The datasets applied are a blend of secondary data sources spanning official government reported statistics and indices and private data from house price and rental indices. Unfortunately, the time period could only commence from 2014 as this is when the rental index was first formed.

2. Relationship to Literature: Does the paper demonstrate an adequate understanding of the relevant literature in the field and cite an appropriate range of literature sources? Is any significant work ignored?: The paper gave a long review of a variety of relevant papers. Starting with the basic DiPasquale-Wheaton four quadrant to give justification for the longrun variables and moving on to more recent work on the price-to-rent ratio. The paper also reviews recent work relevant to Northern Ireland.

Unfortunately, the literature review was meandering and long. The literature review needs to 
be focused on why the variables used in the analysis were chosen. The paper reviewed many authors' work and perspective, yet the theoretical or empirical support for this paper was not well formulated.

We have attempted to streamline the literature and formulate the theoretical and empirical support for the study.

A section on the demand and supply drivers for Northern Ireland's housing market would be useful in helping readers understand why the paper uses the dependent variables in the analysis.

We have included a section on the demand and supply drivers to help position the paper and justify inclusion of the variable subset.

3. Methodology: Is the paper's argument built on an appropriate base of theory, concepts, or other ideas? Has the research or equivalent intellectual work on which the paper is based been well designed? Are the methods employed appropriate?: No. The empirical model was not supported or explained by the literature review.

We have attempted to bridge this gap and enhance the linkages between the literature and the empirical models applied

The empirical analysis could be further expanded. For example: why only show results for one cointegrating relationship? Why not show the eigenvalue test? Why was only ECM used and not work on a VECM? Given the number of variables spanning economic, financial, currency exchange, it was not convincing that only one cointegrating relationship existed between so many factors and the price-to-rent ratio. Where was the support that four years' data was sufficient to effect one housing investment/rental cycle?

We have clarified the methodological approach used (bivariate cointegration) and incorporated the Eigenvalue test.

4. Results: Are results presented clearly and analysed appropriately? Do the conclusions adequately tie together the other elements of the paper?: Presentation could be improved. The equations showing the relevant dependent and independent variables were sorely missed.

We have further clarified the methodology and provided an example context to the equations.

However, the discussion of the results in relation to Northern Ireland's housing situation was good. The caveat here being the reader had a good understanding of the underlying drivers of Northern Ireland's housing market. 
We hope that the inclusion of the demand/supply discussion in the introduction helps triangulate this aspect.

5. Implications for research, practice and/or society: Does the paper identify clearly any implications for research, practice and/or society? Does the paper bridge the gap between theory and practice? How can the research be used in practice (economic and commercial impact), in teaching, to influence public policy, in research (contributing to the body of knowledge)? What is the impact upon society (influencing public attitudes, affecting quality of life)? Are these implications consistent with the findings and conclusions of the paper?: The paper started with a very big picture, and ended with a very big picture. However, as a reader, I find it hard to see how the middle pieces fit together. For example, in the beginning, the paper started with the GFC, 'switching dynamics', macro prudential policy design, etc. I do not see how these concepts were represented in the empirical analysis. Yes, M3, forex and the stock market were used in the analysis, but how did these variables tie in with Northern Ireland's macroprudential policies to regulate housing during 2014-2018? From basic research on the web, Northern Ireland's housing market during that particular period was influenced by demographics, job expansion, low-cost housing attracting inward migrations, etc. All these were not discussed in the paper.

We have attempted to integrate discussions and context to rectify the reviewers' comment.

Moving forward, the relevance of the findings in the covid-era is also questionable. The paper would need to present the case why the findings are still relevant in today's context.

We note the reviewers' comment. Research has tended to illustrate that the COVID impact on housing markets is ephemeral (See Duca et al. 2021). This research was conducted with the UK's decision to leave the EU which also resulted in a S-T market shock, so whilst different in terms of origin we feel that there is currency and relevancy to the findings. Also, it may offer relevancy in the wake of the COVID-19 on the impacts of monetary supply, inflation etc. due to quantitative easing.

6. Quality of Communication: Does the paper clearly express its case, measured against the technical language of the field and the expected knowledge of the journal's readership? Has attention been paid to the clarity of expression and readability, such as sentence structure, jargon use, acronyms, etc.: Overall, the paper was readable and relatively well-written. It would have been better if the ideas were streamlined to clearly indicate the relevance between the literature review, Northern Ireland's housing market, and the variables used in the analysis.

We accept the reviewers point here. We have attempted to revise the paper to sharpen and focus it.

Referee(s)' Comments to Author:

Referee: 2 
This is a well written paper and the topic, whilst not new, is appropriate for the journal although there literature review seems very limited on the cointegration elements of the study and why certain variables were chosen for the model. This needs to be improved.

The biggest problem with the paper is its flow. It feels very disjointed and each part (Lit Review, background on market and choice of variables) feels disconnected from each other. The paper needs to be restructured.

We have attempted to streamline the literature and formulate the theoretical and empirical support for the study. We have included a section on the demand and supply drivers to help position the paper and justify inclusion of the variable subset. We have attempted to bridge this gap and enhance the linkages between the literature and the empirical models applied

It also needs to expand the market commentary. I have a working knowledge of both the NI and Eire residential markets but, for a less informed reader, the background commentary needs to be expanded and explained better.

We have inserted a discussion relating to the market over the period and included more context.

And, as noted, this is a common complaint throughout the paper. The authors need to explain and justify what they are doing, why it is important and how it adds to the literature. At the end of the paper, I am left thinking "so what". A good paper will answer that concern. We have attempted to rectify this and provide more policy and practice implications and where the paper adds contribution.

But, that said, the paper has merit. I am guessing that this was written by an academic researcher with little, if no, input from any practitioners. As such, the paper assumes too much and explains too little. I want to know the practical and real world application of this research.

As indicated above, we have attempted to develop the practice and real world significance of the work. The authors comprise a blend of academics with both experience in professional practice and academia. Upon reflection we can see why the reviewer has made this point. We have provided in Conclusions some relevant practical considerations and policy implications arising from the research. 